\title{
A polgári értékek szolgálatában
}

\section{In the Service of Citizens}

ÖSSZEFOGLALÁS

Horváth János életregénye, Zsiros Mária és Menyhárt Ferenc által íródott, $A z$ élet sava-borsa a fellelhetô dokumentumokra és rengeteg személyes beszélgetésre építve tárja elénk a közel egy évszázados, lebilincselốen izgalmas, fordulatokban gazdag életutat. Csúri Ákos Két pogány közt - törhetetlenül címú könyvében kimondottan Horváth János országgyúlési képviselôi pályafutását veszi górcsố alá. A két kötet forrásértékú és a történettudomány számára is jelentôs emlékei tárulnak az olvasó elé, melybôl kitúnik a nemzetért és hazáért mindenkor felelôsséget érzô ember politikai hitvallása.

Kulcsszavak: interjúkötet, gazdaságpolitika, 20. századi történelem

\section{Summary}

The book entitled Az élet sava-borsa [Salt of Life] is a fascinating life story, rich in incredible turns of events and spanning nearly a century, written by Mária Zsíros and Ferenc Menyhárt on the basis of documents and numerous personal talks with János Horváth, the youngest Member of Parliament in 1945 and the oldest one between 2003 and 2014, sentenced to death during WWII and sentenced to 4 years of forced labour after the 1956 Revolution, former professor at the Butler University and visiting researcher at the Columbia University, USA. The other book entitled Két pogány közt - törhetetlenül [Between Two Pagans - Unbowed] also tackles the life of János Horváth. The two books present the reader with memories of historical significance, revealing the political credo of a person who has always felt responsibility for his nation and his homeland.

Keywords: book of interviews, economic policy, history of the 20th century

Prof. DR. Lentner Csaba egyetemi tanár, a Nemzeti Közszolgálati Egyetem Közpénzügyi Kutatóintézetének vezetôje (Lentner.Csaba@uni-nke.hu). 
A közelmúltban mutatták be azt a kortörténeti dokumentumnak tekinthetó két kötetet, mely Horváth János profeszszor, politikus fordulatos életét rajzolja elénk. Zsiros Márta és Menyhárt Ferenc társszerző́k $A z$ élet sava-borsa címet viselô kötetükben hozzáértố stílusban öntötték irodalmi formába a Horváth Jánossal folytatott beszélgetések nyomán feltáruló, változatos élettörténetet. A lebilincselóen sodró lendületú és tág perspektívát nyitó könyvben egy rendkívül gazdag életpálya fordulatait izgulhatják végig az olvasók. A fôszereplô, akit Cecén a szomszédjuk, Illyés Gyula nagyanyja tanított írni-olvasni, késôbb Budapestre került, 1944-ben bebörtönzi a Gestapo, a nyilasok halálra ítélik, majd kiszabadul. 1945-ben a kommunisták bástyájának számító Angyalföldön legyốzi a nemzetgyúlési választásokon a vele egy kerületben induló Kádár Jánost, képviselố lesz a Kisgazdapárt színeiben, majd rövidesen ismét börtönbe kerül a Magyar Testvéri Közösség tagjaként, koholt vádak alapján. Amikor 1950ben kiszabadul, még mindig csak 29 éves. 1956 októberében a Magyar Forradalmi Gazdasági Tanács tagjaként vesz részt a gazdasági kormányzat felállításában, de a szovjetek visszatérését követôen előbb Bécsbe menekül, majd tovább az Egyesült Államokba. Itt végleg a tudomány mellé szegődik, és egyetemi tanárként megkezdi sok évtizedes tudományos pályáját.

A vidéki, paraszti-kisnemesi környezetbốl érkezố és saját erejére támaszkodva bámulatos hazai és nemzetközi pályát befutó fiú története nemcsak a Dickens-féle Szép remények tökéletes ellenpontját adja, de egyúttal páratlan áttekintést nyújt a 20. századi magyar történelem fordulatairól is. Horváth János az 1956 elốtti korszak számos fontos politikai sze- replójérôl ad elsố kézbôl beszámolót. Késôbb, már az Amerikai Egyesült Államok köztiszteletben álló egyetemi tanáraként lesz vendégprofesszor Ferdinand Marcos elnök alatt a Fülöp-szigeteken, illetve látja vendégül többek között Göncz Árpádot a Butler Egyetemen. Elóször a 80-as években látogathatott haza egy-egy tudományos konferenciára, majd amerikai karrierje után, 1998-ban újra a magyar parlament tagja lett, és az egyetemi-akadémiai világból hozott közgazdaság-tudományi szakértelme jogán a rendszerváltás utáni politikai-gazdasági átalakulásból ismét tevốleges részt vállalt.

A másik bemutatott kötet, Csúri Ákos Két pogány közt - törhetetlenül címú, szép kivitelezésú, kemény táblás könyve rendhagyó múfajú: egyrészt a Horváth Jánossal készült interjúkat fúzi egybe, másrészt több jelenlegi politikus és közéleti szerepló, a politikai paletta minden oldala megszólal benne (a kereszténydemokrata Semjén Zsolt, a polgári értékrendú Kövér László, a liberális Szent-Iványi István, a baloldali Hiller István), egy-egy kiragadott emléket közreadva a nagy formátumú kisgazda politikusról. A kötethez az előszót Magyarország miniszterelnöke, Orbán Viktor írta. Az interjúk és az emlékezések mellett szemezgethetünk Horváth János parlamenti felszólalásaiból is.

Egy-egy korosodó emberrel készített életútinterjú kapcsán a szerzôk gyakran hirdetik, hogy könyvük múfaja „személyes történelem". Amiból a személy is, meg a történelem is (hiszen minden egyes napunk a történelem nagy egészének része) stimmel, ám a kettô valahogy mégsem fér össze. Ezzel a könyvvel más a helyzet: aki végigélte a történelem viharait, hogy aztán 1998-ban hazajöjjön, és megalapozza napjaink sikeres gazda- 
ságpolitikáját, és immáron országgyúlési képviselóként szolgálja hazáját 2014-ig, nos, annak kapcsán, aki mindezt megélte és véghez vitte, beszélhetünk személyes történelemrốl.

Humorral bôségesen átitatott életút-elbeszélés ez a könyv, melyből gyermekeink, unokáink hitelesen megismerhetik a 20. század magyarságának történetét. Bár a könyv nem tankönyvnek készült, olvasmányossága biztosan további és hiteles kutakodásra ösztönzi a felnövố generációt. Egy kivételes egyéniség, sokoldalú, széles körú és magasszintû múveltségú ember meséli el a valós történetét, és véleményezi a jelen szereplőit is. Mondatait nem lehet egyetlen legyintéssel elintézni.

Sokkal inkább annak felvétele, ami ôt élete eddigi 97 évében jellemezte: az alázat.

Bár a könyv az életút fényében nem túnik vaskosnak, de a szövegeknek súlyuk van. Újraolvasandó, hogy megértsük: miért tartunk ma ott, ahol tartunk.

Horváth János Cecén született, 1921. november 7-én. 1945 és 1947 között nemzetgyúlési, majd 1998 és 2014 között országgyúlési képviselố volt. 2003 és 2014 között a legidôsebb képviselố és ebbôl adódóan az Országgyúlés korelnöke is volt. Az 1956-os forradalom leverése után emigrálni kényszerült. Elốbb Strasbourgban a Magyar Forradalmi Tanács egyik szervezője, majd New Yorkban a Kossuth Alapítvány egyik létrehozója lett. 1958 és 1966 között közgazdaságtant hallgatott a Columbia Egyetemen, ahol meg is szerezte közgazdaság-tudományi doktorátusát. Amerikai tanulmányainak befejezése után az egyetem oktatója, majd 1968-tól a Butler Egyetem közgazdászprofesszora lett. Kutatási területe az infláció, a munkanélküliség, az agrárszféra és a növekedés témakörét ölelte fel.

A rendszerváltás után a Corvinus Egyetemen tartott elôadásokat. 1992-ben a Republikánus Pártjelöltje volt Indiana 10. számú választókerületében. 1998-ban, Orbán Viktor kérésére elvállalta a Fidesz gazdaságpolitikai bizottságának vezetését. Az 1998-as országgyúlési választásokon a Fidesz országos listájáról bejutva 51 év után újra parlamenti mandátumot szerzett, ahogy 2002-ben és 2006-ban is. 2011-ben megkapta a Magyar Köztársasági Érdemrend nagykeresztjét. Jelentôsebb írásai, könyvei: A Theory of Institutional Inflation; Grants Economics; Tiltott történelmünk, 1945-1947; The legacy of the 1956 Hungarian revolution; Éló történelem.

Zsiros Mária - Menyhárt László (2018): Az élet sava-borsa. Horváth János életregénye. L'Harmattan, Budapest, 272 oldal; Csúri Ákos (2018): Két pogány közt - törhetetlenül (Horváth János és az ország háza). Cuikker Média, Budapest, 246 oldal. 


\section{A három születésnapi kívánságom}

\section{My Three Birthday Wishes}

ÖsSZEFoglalás

Magyarország egyik legismertebb közgazdásza arról értekezik, hogyan vette birtokba az ember a földet az évezredek során. A jelenkor karakterét már az ember határozza meg, ezért korunkat antropocénnek, azaz az emberhez igazodónak kellene tekinteni. A kommunikációban megszúntek a távolságok.

Journal of Economic Literature (JEL) kódok: F22, N3, B10

Kulcsszavak: puritantizmus, túlnépesedés, antropocén, bevándorlás

\section{SUMmary}

One of Hungary's best-known economists discusses how humans gradually took possession of land in the course of thousands of years. As the character of our time is already determined by humans, this historical period should be considered anthropocene, i.e. "adjusted to man". Distances have ceased in communication.
Journal of Economic Literature (JEL) codes: F22, N3, B10

Keywords: puritanism, overpopulation, anthropocene, immigration

A SZELLEMIVAGYON-TERMELÉS PIACOSÍTÁSA

A jelenkori társadalmak fejlódési tempója egyre inkább attól függ, hogyan gyarapodik a szellemi vagyon. Ezt már az 50-es években megtanultam Max Webertốl, aki a múlt század fordulóján megállapította: a tudományos és technikai forradalom olyan társadalmi alépítményt hozott létre, aminek felépítményét másoknál hatékonyabban csak a protestáns népek képesek múködtetni. Azóta a társadalmi fejlődés hatékonyságának a felismerését a tények fényesen igazolták, ha a tételét két módosítással egészítjük ki.

Protestáns helyett puritánt kellett volna mondani. Weber protestánsként abban a meggyôzốdésben élt, hogy azért

Dr. KopÁTsy SÁNDOR, közgazdász (kopatsy.sandor@t-online.hu). 
puritánok a protestánsok, mert ezeket a kereszténységük puritánságra nevelte. $\mathrm{Az}$ összefüggés azonban fordított. Európa térségének északnyugati harmadában a skandinávok, az angolszászok és a germánok eleve, már a kereszténység felvétele elótt is puritánok voltak. Ezért aztán ahogyan nagykorúak lettek, a nem puritán római katolikus kereszténységüket felváltották a megreformált, puritánabb kereszténységre.

A távol-keleti konfuciánus népek legalább annyira puritánok, mint a Nyugaton a protestánsok. Az ipari forradalom elôtt a távol-keleti népek társadalmai a Nyugat puritánjai elốtt jártak. A történészek máig nem tárták fel, hogy a keményen puritán távol-keleti népek azért maradtak le a Nyugat puritánjaihoz képest, mert nagycsaládosak voltak. Ahogyan azonban iparosodva ezek is kiscsaládosak lettek, a 20. század folyamán fokozatosan felzárkóztak a világ társadalmi élvonalába. Jelenleg már vitathatatlan, hogy a 21. század derekára minden távol-keleti ország fejlett lesz. Ideje volna azt felismerni, hogy minden társadalom sejtje a család. Ez a Homo sapiens életében mindig nagycsalád volt. Az elsô kiscsaládos társadalom a nyugat-európai feudális társadalom volt, ezt megelózốen a földmúvelố társadalmak nagycsaládosak voltak. Annak jelentôségét a történészek máig nem ismerték fel, hogy a nyugat-európai jobbágyrendszer kiscsaládos volt.

Weber sem ezt ismerte fel. A nyugat-európai népek nem a reformációnak, hanem a kiscsaládnak köszönhetik, hogy a viselkedésük puritán lett. A puritán népek viselkedésüknek köszönhetôen a többi kultúrát megelőzik a társadalmi fejlettségükkel.

Weber megállapítása azt jelenti, hogy a lakosság puritán viselkedése a társadal- mi fejlődése számára a fizikai tốkénél is fontosabb. Ennek ellenére a jelenkori közgazdaságtan százszor annyit foglalkozik a fizikai vagyon tulajdonformájával, mint a szellemi tóke társadalmi szerepével. Ma már a lakosság viselkedése fontosabb, mint a fizikai vagyon tulajdonformája. Ebbốl fakad, hogy csak a fizikai tôkét tekintjük értékével mért árunak, az ennél sokkal nagyobb értékké vált szellemi tôke pedig értéke nélkül mozoghat az országok között.

Vitathatatlan tény, hogy a tudományos és technikai forradalom óta a legnagyobb érték az ember, annak értékét mégsem vesszük figyelembe. Ebból fakad, hogy a legfontosabb értéknek, a munkaerőnek az értéktermelését, az oktatást nem tartjuk értéktermelésnek, azt nem a piacra, hanem az állam politikai hatalmára bízzuk.

Ha valaminek a piacosítására megérett a jelenkori fejlett társadalom, akkor az oktatás az, amit a piacra kell bízni. Ez az elmaradt társadalmakban jelenleg jobban megindult, mint a fejlettekben, ahol legfeljebb a vallásokat vonták be az oktatásba annak ellenére, hogy erre azok a legkevésbé alkalmasak, mert abban nem az eredmény, hanem a dogmák tisztelete az elsô. A gyermekek elsôsorban a szülốk tulajdonai, a felnevelésük módjának megválasztását azokra kell bízni. Ezzel szemben a jelenkori fejlett társadalmakban továbbra is úgy kezelik az iskolarendszert, mintha a gyermek az állam tulajdona volna.

Mivel a jelenkori társadalom hatékonyságát elsôsorban a lakosság értéke határozza meg, a versenyképessége a lakosság képességén múlik. Az mégsem jutott a társadalomtudósok eszébe, hogyan mérjük ezt a legnagyobb értéket, és mit kell tenni a növelése érdekében. 
Az ezredforduló környékén az agykutatók néhány négyéves gyermek szókincsét felmérték. Erre ma a számítógépek lehetôséget adnak. Erre az agykutatók hívták fel a figyelmet, azt állítva, hogy az ember abban is más fejlettségi szinten születik, hogy az elsố négy-öt évben fejezôdik be az agyfejlődés. Az ember újszülöttje abban is különbözik a biológiai elôdeitôl, hogy életképtelenebbül születik. Az állatvilágban az életképességhez elsôsorban az ösztönökre van szükség: az újszülöttek vagy azonnal életképesek, vagy nagyon rövid idő alatt azzá válnak. Ezzel szemben az újszülött gyermek életképtelen, nem tud járni, beszélni, a szülei gondoskodására szorul. Az csak utólag vált felismertté, hogy az agyfejlődéshez négy-öt évre van szükség.

Az agy fejlettségét a szókinccsel mérték. A használt szavak számát kincsnek minôsítették a nyelvek. Az ember biológiai fölényét a fejlett agyának, a nagyon sok feladat elvégzésére alkalmas kezeknek és a hangképzésnek köszönheti, mégsem ezeket, hanem a használt szavak számát hívják kincsünknek. Hogy a 4-5 éves korban használt szavak száma valóban kincs, csak tíz-tizenöt éves tapasztalat alapján derült ki. A tanulási eredmények és a gyerekkori szókincs között ugyanis nagyon szoros a korreláció. Azt, hogy kinek milyenek lesznek a tanulási eredményei, meg lehet állapítani abból, hogy 4-5 éves korban hány szóval kommunikál. Az is egyértelmú, hogy a gyerekek szókincse két feltételen múlik: egyrészt mennyire iskolázottak a szülók, másrészt mekkora gyermekközösségben élnek.

A mesemondó szülôk ösztönösen azért meséltek a gyermekeiknek, mert a mesék más életkörülményeknek megfelelô szókincset tartalmaznak. Azt, hogy miért játszottak a szent szövegek, a legendák, a versek fontos szerepet, csak akkor értettem meg, amikor a szókincs jelentôségét megismertem. Ezt megelốzve a reformáció bibliafordításait a vallás érdekét szolgálónak tartottam, most már tudom, hogy milyen fontos szerepe volt a Biblia szinte folyamatos olvasásának. Ez ugyanis többségében olyan szókincset tartalmazott, ami a mindennapi életben nem fordult elô. A Biblia szókincsét azok is megtanulták, akik nem tudtak olvasni. A görög társadalmakban százszor annyian ismerték Homérosz szövegét, azaz szókincsét, mint amennyi olvasni tudott. A költészet társadalmi szerepe is az volt, hogy a szókincset bôvítse. Azt, hogy hogyan hat a szókincsre a rádió, televízió, előre meg sem lehet mondani.

Ezt a témát azzal zárom, hogy a jelenkor száz év alatt megszázszorozta az egyetemen tanulók számát. Ugyanakkor viszonylag kevés figyelmet szenteltünk annak, hogy az egyetemeken elért eredmény elsốsorban a jó magzati kihordáson és az elsố négy évben megszerzett szókincsen múlik.

\section{A GYERMEKNEVELÉS TÁRSADALMI TÁMOGATÁSA}

A jelenlegi kormány jó irányban mozdul azzal, hogy a gyermekvállalást nemcsak darabszáma után, hanem adókedvezménnyel, azaz a szülók jövedelmével arányosan is támogatja. Sajnos addig még nem jutottunk el, hogy felmérnénk, milyen szülői háttér mellett milyen a gyermeknevelés eredménye. Meggyôzôdésem szerint a gyermeknevelés elsôsorban a szülók iskolázottságától és jövedelmétôl függ. Ezért vagyok megszállott híve az olyan nyugdíjrendszernek, aminek nagysága nem a szülók életkeresetétôl, hanem a gyermekneve- 
lésük eredményétôl függ. Aki tudomásul veszi, hogy a társadalom jövôje elsôsorban a következô generáció minôségétől függ, ezért az öregekrôl való társadalmi gondoskodást a gyermekei felnevelése arányában biztosítsa.

A családtámogatásban máig nem tudatosult, hogy az a társadalom érdekével ellentétes, a gyermekvállalást kontraszelekcióssá teszi. A gyermekek számához igazodó támogatásnak az a következménye, hogy a gyermekvállalás a szülók jövedelmével és iskolázottságával fordítottan arányos. Nagyobb kárt talán egyetlen támogatási rendszer sem tesz, mint a jelenlegi családi pótlék.

Érthetetlen, hogy a jelenkor tudományos világa nem veszi tudomásul, hogy fajunk közel száz éve kontraszelekcióval és elviselhetetlenül gyorsan szaporodik. Az emberiség jelenleg kisebbik fele, a puritán fejlett és gyorsan fejlôdô társadalmakban vagy spontán leállt, illetve Kínában erôszakkal megállították. A már fejlett, gazdag ötödben gyorsan javulnak az egy lakosra jutó mutatók. A nagyon alacsony szintról példátlanul gyors fejlődés történik. E térségben, ami a társadalmi fejlődés motorja, kontraszelekciós a következô generáció újratermelése. Ennél nagyobb veszély egy fajt nem is fenyegethet. Ennek csak azért nincs még katasztrofális hatása, mert javulnak a kontraszelekciós nemzedéknek az életfeltételei és a képzése.

Az emberiség nagyobb fele azonban tízszer gyorsabban szaporodik, mint valaha a múltjában. Ennek ellenére abban is példátlanul javul az élelmezés, gyorsan csökken a halálozás, és nô a várható életkor. Ennek együttes hatására évente 70 millióval, tehát elviselhetetlenül nố a lakosság száma. Az emberiség demográfiai kettészakadása következtében elôször tör- tént meg az, hogy az emberiség nagyobb, egyre jobban lemaradó felében a lakosság nagy többsége számára a jobb életfeltételeket akkor is csak a gazdag társadalmakba való áttelepülés jelentheti, ha ott az alsó jövedelmi tizedben maradnak.

A társadalomtudományok máig nem ismerték fel annak a történelemformáló hatását, hogy a fejlett társadalmakban a szegények, az alsó tized is sokkal jobban élhet, mint az elmaradt társadalmak lakosságának kilenctizede. Az osztálytársadalmak világában ugyanis a lakosság óriási többsége, a rabszolga, a jobbágy és a proletár alig élt jobban, mint az elmaradtabb társadalmak átlaga. Jelenleg a jóléti országokban nemcsak a dolgozók, de még a munkanélküliek is sokkal jobban élnek, mint az elmaradt társadalmak népességének a nagy többsége. Ebbôl a ténybôl fakad az, hogy az emberiség lemaradó kétharmadában a lakosság nagy többsége örömmel élne a fejlett társadalmak alsó tizedében. Legalább kétmilliárd ember él úgy a lemaradó társadalmakban, hogy nincs semmi reménye, lehetôsége arra, hogy otthon maradva úgy élhessen, mint a jóléti társadalmakban az alsó tized. Ez ma olyan tény, amirôl a kommunikáció forradalmának köszönhetôen ezek az emberek nemcsak láthatják azt a tényt, de a közlekedés fejlettségének köszönhetően el is érhetik. Ugyanakkor a fejlett világban ezredennyi bevándorló befogadására sem képesek.

\section{A Homo SAPIENS MEghódítotTa A FÖLDET: AZ ANTROPOCÉN}

Száz éve senkinek nem volt fogalma arról, mit érünk meg máig, még kevésbé lehet felmérni azt, hogy hol lehetünk száz év múlva. Az ugyan valószínú, hogy a tudományos és technikai fejlôdés tovább gyor- 


\section{Tudományos múhely}

sul, de annak a részletein reménytelen jóslatokba bocsátkozni.

Amikor pár napja barátaim Yuval Noah Harari Homo Deus címú könyvével megajándékoztak, a könyv azonnal bemutatkozott. Véletlenül a 70. oldalán nyílt ki, ahol egy grafikont láttam az emberek és az egy kilónál nagyobb testú házi és vadon élô állatok biomasszájának arányáról. Ez elég volt arra, hogy elhatározzam, erre a könyvre rászánok egy hónapot, és leírom a véleményemet. Másnap újra itt nyitottam ki a könyvet, és meglepôdtem az ábra elótti lapon a fejezet címén: Antropogén, az ember által formált korszak.

Annyit már a 80-as években tudtam, hogy egy szovjet tudós vetette fel elôször, hogy a földtani, a heliocentrikus korok lejártak, a jelenkor karakterét már az ember határozza meg, ezért korunkat antropocénnek, azaz az emberhez igazodónak kellene tekinteni. Ezen ma is tudományos vita folyik. Harari ábrája azonnal meggyôzött. Jelenleg az ember és a háziállatai teszik ki a földön éló biomassza közel 90 százalékát. A vadon élố állatok pedig csupán a tizedét. Alig tízezer éve, azaz a földtani korok idôszakaihoz szinte a jelenben, e megosztásban 99 százalék volt a vadon éló állat. Az ember és az akkori egyetlen háziállat, a kutya aligha haladhatta meg az egyetlen százalékot. Mára az ember és háziállatainak súlya megszázszorozódott. Ekkora biológiai változás nem történt egyetlen sokszáz millió éves heliocentrikus korszakban sem.

Tízezer éve legfeljebb néhány tízmillió, jelenleg 7,5 milliárd ember él a világon. Még nagyobb változás történt az embert szolgáló háziállatok esetében. Ma nemcsak közel ezerszer annyi ember él, mint tízezer éve, de ezek átlagsúlya akkor legfeljebb negyven kiló lehetett, most hatvan kilónál is több. Harari szellemesen azzal jellemzi e változást, hogy a gyújtögetô emberek nagy többsége azért halt meg korán, mert alultáplált volt, jelenleg pedig a túlsúlyosságban többen halnak meg, mint az alultáplálkozás okán. A szembeállítás szellemes, de félrevezetô, mert a túlsúlyos emberek is háromszor tovább élnek, mint az éhezés által jellemzett korokban.

Az elmúlt száz évben ugyan megötszörözôdött fajunk létszáma, és ennek ellenére tizedére csökkent a nagyon szegények, az éhezók száma. Kevesen veszik tudomásul, hogy az ENSZ ötven éve a nagyon szegényeknek azokat tekinti, akiknek a napi jövedelme 1,9 dollár alatt van. Száz éve az emberiség nagyobb fele e szint alatt élt. 1990-ben a részarányuk harmadára csökkent, de még mindig 1,5 milliárdnyian voltak, ezek harmada pedig a reform elôtti Kínában élt. Ott mára ez a szegénység megszúnt. Jelenlegi számukat 500 millióra becsülik.

Mintegy tízezer éve az emberiség súlya, szerepe a vadon éló állatokhoz viszonyítva jelentéktelen volt. Az elôtte levô korszakokban az ember szerepe elhanyagolható volt, tehát a földünkön az életet heliocentrikusnak kell tekinteni. Az is aligha vitatható, hogy tízezer éve az ember nem játszott szerepet a klíma felmelegedésében. Ritka faj voltunk, a természeti környezet alakításában nem játszottunk szerepet.

Az ember mégis egy nagyon fontos tekintetben az elsô faj volt, amelyik a többi fajjal ellentétben, a környezetéhez nem úgy alkalmazkodott, ahogyan az az állatvilágban történik, amit már Darwin is megállapított, a mutáció és a szelekció hosszú útján, új fajjá változva. Az ember a fejlett agyával, mellsố végtagjainak ügyességével 
és kommunikációs képességének köszönhetôen a viselkedésével alkalmazkodott. $\mathrm{Ez}$ a magasabbrendúségünk azonban megjelenésünkkor még messze volt attól, hogy a földet maga alá rendelje. E szint közelébe csak addigra értünk el, amikor a felmelegedés elkezdődött.

Ha a felmelegedés elóbb kezdôdik, nem lehetett volna számos növény- és állatfaj domesztikációja lehetséges. A mezôgazdasági tudományok képviselối máig nem vetették fel a kérdést: Hogyan történt a kultúrnövények kinemesítése és a háziállatok domesztikációja? Erre a kérdésre ugyan még nem találtam választ, pedig a biológusok már tudományosan elfogadták, hogy a kultúrnövények: a rizs, a köles, a búza, az árpa lakóhely körüli kapás múvelése néhány tízezer évvel korábban megindult, és ez idố alatt kultúrnövénnyé szelektálódott.

$\mathrm{Az}$ is tudományos tény, hogy a kutya mintegy húszezer éve az emberhez szelídült, és vele együttmúköodve a rénszarvasok vándorló nyájaihoz csatlakozott.

$\mathrm{Az}$ antropocén kor eljövetelének legfontosabb előfeltételét az ember teremtette meg azzal, hogy szolgálatába álította, domesztikálta a maga fehérjével való élelmezését, a szántóföldi növénytermeléshez elengedhetetlen szállítást és talajmû́velést ellátni képes állati igaerôt. Annak érdekében, hogy megértsük, minek köszönhetjük, hogy fajunk viszonylag nagyon gyorsan szolgálatába tudta állítani a földgolyót, fel kell tárni a haszonnövények és a háziállatok ember által történô hasznosítását. Meg kell említeni azt is, hogy az öntözéses szántóföldi földmúvelés létrehozásának volt egy heliocentrikus feltétele is, a tengerszint mintegy 70 méteres felemelkedése. Ez tette lehetôvé, hogy Kelet- és Dél-Ázsia, valamint a Közel-Kelet folyamainak a völgyei gravitációsan öntözhetôk és folyásukkal szemben is hajózhatók lettek. Ez is a heliocén hatásnak volt köszönhetô. Ha nem emelkedik mintegy 70 méterrel a tengerszint, nem lehetett volna gravitációsan öntözni a folyamok síkságait. Bármennyire egyértelmú, említést sem találtam arról, hogy az öntözéses szántóföldi gabonatermelés létre sem jöhetett volna, ha nem emelkedik meg a tengerszint. A kelet-ázsiai, a dél-ázsiai és a közel-keleti öntözéses gabonatermeló kultúrák létre sem jöhettek volna, ha a folyamaik továbbra is a mintegy 70 méterrel alacsonyabb tengerekbe ömlenek. Még a vízügyi szakemberek sem mutattak rá arra, hogy az öntözéses gabonatermelés gazdaságföldrajzi feltételét csak a megemelkedett tengerszint jelentette.

Csak az ember volt képes állatokat domesztikálni, de ezt az ember is csak olyan állatfajokkal tehette meg, amelyek nagy többsége képtelen volt az életmódját az élettere megváltozásához ösztönösen igazítani. A legfontosabb háziállatok: a szarvasmarha, a bivaly, a kecske, a birka vadállatként a nagyon megváltozott eredeti életterében vagy kipusztult, vagy csak néhány, a számára kedvezô élettérben maradhatott volna meg. Domesztikálni ugyanis csak a jelentôs klímaváltozáshoz alkalmazkodni képtelen, kihalásra ítélt fajokat lehetett. A domesztikált fajok kihaltak, vagy a számuk a domesztikált fajtestvéreikhez képest csekély számra apadt.

A jégkorszak megszúnését okozó felmelegedés jókor történt.

Az éghajlat felmelegedését, a természeti környezetek jelentôs megváltozását heliocentrikus okok idézték elô. Az idôzítése véletlen szerencse volt. A jelentôs klímaváltozás nem akkor történik, ami- 
kor az ember már olyan fejlett állapotban volt, hogy ehhez a heliocentrikus váltáshoz képes volt alkalmazkodni. Az éghajlatváltozás azonban akkor történt, amikor az ember már képessé vált arra, hogy embercentrikussá változtassa a földünkön az életet, viszonylag nagyon gyorsan olyanná tette a földet, hogy indokoltan tekinthetjük embercentrikusnak, antropocénnek.

$\mathrm{Az}$ a tény, hogy mára a földünkön antropocén rendszer múködik, annak a folyamatnak a következménye, hogy a földünk klímája a naprendszerben tehát heliocén okból olyan változás történt, aminek a hatására a földön viszonylag gyorsan és jelentôsen megváltoztak az életfeltételek. A heliocén változás ugyan mintegy 10 ezer éve kezdődött, de szinte csak az utolsó száz évben vált a földi élet emberszabásúvá, antropocén típusúvá. A földtörténeti korok sok százmillió éves idôszakaihoz viszonyítva a tízezer év a hibahatárokon belüli idôt jelent.

A történelmünket sokkal könnyebben megértenénk, ha a földünkön élô állatvilág és az emberiség biomasszájának összetételét az elmúlt tízezer évben is megmutatnánk.

Hasonló arányok változását kellene megmutatni a mezógazdaságról is, arról, hogyan alakult a kultúrnövények aránya a gyưjtögethetô, vadon termố növényekhez viszonyítva. Egyértelmúvé válna, hogy nemcsak a földünk bioszférájában, de a flórájában is többségbe kerültek az ember által kiszelektált kultúrnövények.

Ma mintegy százszor több ember és egy nagyságrenddel több állat táplálkozik sokkal jobban, mint elôtte. Ezt annak köszönhetjük, hogy nem a földünk természet adta növényeiból és állataiból élünk, hanem azokból, amit az ember szelektált ki magának.

Harari fontos változásra mutat rá azzal, hogy a földi élet csak a jelenkorban vált szerves egységgé. A kommunikációban megszüntek a távolságok, és az emberiség először tud egymásról. Az utazás mára könnyebb lett a kontinensek között, mint a vasút elôtt az egynapi járóföldnél nagyobb távolság legyőzése volt. Gyermekkoromban még az is ritkaságnak számított, hogy valaki másik faluba költözött. Nagyon meglepett, amikor még diákkoromban azt olvastam, hogy a középkori házasságok 95 százalékát a néhány száz lakosú falvakon belül kötötték. De még gyermekkorom falujában is, aki szomszéd faluból házasodott, azt szinte idegennek kezelték. Azt is különleges eseményként kezelték, ha valaki ugyan a falun belül házasodott, de az egybekeltek nem ugyanazon keresztény egyházhoz tartoztak. A jelentôs vagyoni különbségúek házasságkötését még inkább természetellenesnek minôsítették.

Fajunk elôször vált biológiai egységgé. 


\section{Közszolgáltatások és térbeli koncentráció}

\section{Public Services and Spatial Concentration}

ÖsSZEFOGLALÁs

Térgazdaságtani szempontból a versenyképesség felfogható a térségek népességmegtartó és tôkevonzó, illetve munkahelyteremtő képességének jellemzőjeként. Ennek szellemében a területi versenyképesség a meglévố és fenntartható infrastruktúrán, az elérhetô közszolgáltatásokon, valamint a meglévố foglalkoztatottsági színvonalon (és a mindezek által biztosított vonzó életkörnyezeten) is mérhetô.

A jelen tanulmány egyik alapkérdése az volt, hogy bizonyos közszolgáltatások fokozott jelenléte elôidézi-e a gazdaság térbeli koncentrációját. Ennek szellemében tanulmányunkban áttekintést kínálunk a közszolgáltatások tipizálásáról és a területi versenyképességhez kapcsolódó irodalmáról; konceptualizáljuk a területi tôketípusok és a közszolgáltatások kapcsolatát; majd a Magyarország vidéki településein végzett fơkomponens- és klaszteranalízis segítségével szemléltetjük a gazdasági koncentráció, a lakosság jóléte-jólléte és a közszolgáltatások térbeli elhelyezkedése közötti hasonlóságokat és különbözőségeket.

Journal of Economic Literature (JEL) kódok: H50, C18, H41, H75, R12

Kulcsszavak: közszolgáltatások, versenyképesség, koncentráció, fôkomponensés klaszterelemzés

\section{Summary}

From a spatial economic aspect, competitiveness can be considered an indicator of the region's ability to maintain its population, to attract capital and to create workplaces. According to this, spatial competitiveness can also be measured through the existing and sustainable infrastructure, the available public services

Szabó Tamás doktorjelölt, Pécsi Tudományegyetem, Regionális Politika és Gazdaságtan Doktori Iskola (tamas.szabo@transportresearch.net), KovÁcs EszTer doktorjelölt, Pécsi Tudományegyetem, Regionális Politika és Gazdaságtan Doktori Iskola (info@gipfeltext.com). 
and the current level of employment (and through the living environment granted by these indicators).

One of the central questions of this study was if the increased presence of certain public services induces the spatial concentration of the economic space. With this in mind, in our study we provide an overview of the types and the literature on the topic of spatial competitiveness of the public services; identify the types of spatial capital; and later run a principal component and cluster analysis on the Hungarian settlements (except the capital) in order to identify the territorial similarities and differences in economic concentration, the welfare and the existence and intensity of the public services.

Journal of Economic Literature (JEL) codes: H50, C18, H41, H75, R12

Keywords: public services, competitiveness, concentration, principal component and cluster analysis

A területi versenyképesség napjainkban számos aspektusból az elemzés tárgya, viszont a különbözó interpretációkból még hiányzik a terület lakónépességének életminôségét és esélyeit jelentôsen befolyásoló állami feladatellátás intenzitásának, a közszolgáltatások hozzáférhetôségének részletesebb, fejlesztési szempontú vizsgálata. Annak ellenére, hogy a versenyképességet az európai közgazdaságtani felfogásban a kibocsátás nagyságával mérik (Camagni-Capello, 2013), méltatlanul reked kutatási területen kívülre a nemzetgazdasági erôforrások endogenizálása.

A fiskális intézménymenedzsment szerint a közmenedzsment akkor válhat versenyképessé, ha a tulajdonosi szemléletból visszaköszönnek a tudatosság múködéshez köthetô dimenziói. Ennek megfelelóen a jó közmenedzsment a versenyképesség előfeltételei közé tartozik, és a múködtetésnek érték- és céltudatosnak kell lennie. A múködtetés során a módtudatosságot fontos alkalmazni, amelynek az a lényege, hogy a feladatellátásban a célok tisztázása és a megvalósításhoz használt programok szinergiája érvényesüljön. A képességtudatosság feltételezi a szervezet képességleltárát, amelynek révén a hiányosságok megszüntethetốk. A forrástudatosság pedig a mérlegszemléletúséget emeli ki a versenyképességet segítô tényezốk közül. A környezettudatosság a közremúködố partnerek kapcsolódási lehetôségére világít rá (Kovács, 2007), az utóbbi pedig értelmezhetố úgy is, mint a rendelkezésre álló belsố erôforrások kihasználása.

Ugyancsak a belsố erőforrások fontosságára hívja fel a figyelmet a pénzügyi közgazdász, aki a humán erőforrás, illetve az oktatás minôségi kritériumait, a „humán erőforrás bóvített reprodukcióját" jelöli meg a versenyképesség egyik alaptényezôjének (Lentner, 2007). A szerzố - a stabilitást garantáló pénzügyi konvergenciacélok mellett - a szakképzett munkaerô aktuális állapotának javításában látja a versenyképesség garanciáját.

A belsố tényezôs erôforrások külön befektetést nem igényelnek a nemzetgazdaság részérôl, de fontos, hogy a területi politika alkotói kiaknázzák a lakónépességben, illetve a térségekben rejló potenciált, mert egyfelôl csökkenti a nemzetgazdasági kitettséget, másfelôl pedig fejleszti a lokálpatriotizmust. Ugyanakkor gátat szabhat azoknak a veszélyes szocio-ökonometriai látens funkcióknak, amelyek a térszerkezet demográfiai, valamint erőforrásstruktúra-átrendezôdésé- 


\section{Tudományos múhely}

ért felelôsek. Az ilyen jellegú folyamatoknak szabhat gátat, ha az érintett térségek önkormányzatai kihasználják a térségek helyi erőforrásait és technológiai, valamint piaci elônyeit. A térségek belsố erőforrásainak észszerú kiaknázása, hatékony mozgósítása révén javítható azok potenciálja, és ezzel együtt a lakónépesség jóléte is (Camagni-Capello, 2013). A szerzôpáros empirikus kutatásában az alábbi versenyképességi faktorokat deklarálja:

- a helyi termelói aktivitást, a tradíciókat, valamint a képességeket és a különbözố know-how-kat;

- az egyes tôkefajták térben koncentrált rendszerét - mint például a társadalmi, illetve humán tôke -, hangsúlyozottan szinergikus múködési jelleggel;

- kulturális és értékrendi elemeket, amelyek képesek strukturálni és definiálni a helyi identitást, ideértve például a helyi termékek és szolgáltatások piacát;

- olyan szabályozórendszert, amelyben a törvényhozók (esetünkben a rendeletalkotó önkormányzat, illetve hatósági szervek) kiszolgálják a lakossági érdekeket.

Kétségtelen tény, hogy a fenti faktorok kevésbé tartoznak az operacionalizálható kategóriák sorába, de az bizonyos, hogy a fenti gyakorlat bevezetése eredményeként olyan multiplikátorhatás érhetô el, amely a lokális, NUTS3-as szint alatti területek gazdasági teljesítményének trendjében is mérhetô. Hazánk esetében az egyes térségek gazdasági pólusait azok ipartörténete és gazdaságföldrajzi helyzete determinálja. A belsố erôforrások mozgósítása a szocialista iparosítás fellegvárainak térségeiben különösen azon területek esetében válhat fokozottan indokolttá, ahol a gazdaságföldrajzi pozíció és az infrastruktúrával való ellátottság nem olyan kedvezô, mint például az M1-es autópálya mentén elhelyezkedô, korábbi iparvárosok tekintetében. Utóbbiakba a tôkebeáramlás már a rendszerváltás környékén intenzív volt, de az infrastruktúra-fejlesztésnek köszönhetóen a termelővállalatok száma is növekedett, amelynek eredményeként a munkaerópiac felpezsdült, illetve a munkaerố is mobilabbá vált (Siska-Szabó, 2015).

Jogosan merül fel a kérdés, hogy vajon milyen felzárkózási lehetôség jut azoknak a térségeknek, amelyek a betelepüló tôke látókörén kívülre szorulnak, mert a rossz infrastrukturális ellátottságuk vagy kedvezôtlen földrajzi helyzetük növeli a logisztikai költségeket.

A makro- és a térgazdaságtani közgazdászok versenyképességi nézetei azonos irányba mutatnak tehát: a nemzetgazdasági színtéren értelmezett és mért versenyképesség egyes elemei mikroszintú eredmények aggregációjával jönnek létre, és ezeknek alapja a helyi közigazgatási szinten teremtôdnek meg (Palotai-Virág, 2016). A nemzetközi szakirodalom a külsố forrásoknak kitett nemzetgazdaságok eseteinek vizsgálatakor tér ki a területi tôke fogalmára, amely értelmezésében két fô dimenziót javasol a fogalom körülhatárolására, ezek pedig a versengô és az anyagiasult javak jelenléte a vizsgált területeken. A versengó javak esetében a közgazdaságtan elkülöníti a tiszta közjavakat, ${ }^{1}$ a vegyes közjavakat, a magánjavakat, valamint ezeken túl egy köztes jószágot, az ún. klubjavakat (Nordhaus-Samuelson, 2012). ${ }^{2}$

$\mathrm{Az}$ anyagiasult javak kategóriája tartalmazza a tárgyiasult javakat (tangible goods), az immateriális javakat (intangible goods), valamint az ún. hard-soft java- 


\section{Tudományos múhely}

kat, ami az iménti kategóriák speciális elegye (Camagni-Capello, 2013). Utóbbiak tartalmazzák azokat a virtuális (digitális) vagy szolgáltatás jellegú javakat, amelyek a hazai közszolgáltatások gyakorlatában leginkább az e-közigazgatás egyes részeit foglalják magukban.

Figyelembe véve, hogy a közjavak elôállítása nem konkrét helyhez kötötten történik, illetve a finanszírozásuk tekintetében sem közigazgatási, sem területi értelemben nem egy helyen jelenik meg, továbbá a hozzáférhetôség intenzitása sem azonos, hatással van a területi versenyképességre, illetve ezen keresztül differenciál. Ezen tulajdonságok révén a közszolgáltatások hozzáférhetôsége befolyásolja a térségek lakónépességének jólétét és helybenmaradási hajlandóságát, valamint versenyképességi esélyeit.

Az állami feladatellátás és a tôke közötti kapcsolatot - közgazdaságtani értelemben - a társadalmi tôke biztosítja, ami „olyan cselekvési képességekre, nevezetesen a tulajdonra és a szakmai képességekre vonatkozik, amelyek a gazdasági élet területén más egyénekre gyakorolt befolyás révén elôsegítik bizonyos javak megszerzését" (Farkas, 2013:107). Ezen az interpretáción keresztül vizsgálva a közjavakat, közvetett kapcsolatot feltételezhetünk a közszolgáltatásokhoz való hozzáférhetôség és a területi versenyképesség, illetve a koncentráció között. Szociológiai értelmezésben a (társadalmi) tốke fogalmának konceptualizálása Pierre Bourdieu (1980) és James S. Coleman (1988) nevéhez fúzôdik, akik a tôke fogalmába szimbolikus erôforrásokat, képességeket és javakat is beemeltek. Vegyük észre, hogy a közgazdaságtani tôke - a társadalmi javak finanszírozásán keresztül - pont az összetett társadalmi hatások miatt el- választhatatlan a szociológiai értelemben vett társadalmi tôkétôl; habár ez utóbbi kategóriáit kevésbé lehet számszerúsíteni. Másrészt viszont a szerzók felhívják a figyelmet arra, hogy a társadalmi tôke fogalmában húzódó társadalmi aktivitás olyan tartós kognitív motívum lehet, amely képes mozgósítani egy térség egyes gazdasági aktorait.

A térségek versenyképessége szempontjából nem mindegy - ahogy a gazdasági tevékenység eloszlása esetében sem -, hogy a szimbolikus erôforrások miként súrúsödnek a térben, hiszen ezek karakterisztikája pozitív és negatív externáliaként szerepet játszik a térségek erôforrásainak hatékony aktivizálásában. Tehát - ahogy erre több tanulmány (Pénzes, 2013; Káposzta, 2014) rámutat - a gazdasági hátrányokat tompíthatja a humán tốke markáns és aktív jelenléte, ami a közszolgáltatások hiányára vagy kiesésére ${ }^{3}$ is megoldást nyújthat.

\section{A KÖZSZOLGÁLTATÁSOK DETERMINÁCIÓI}

A közszolgáltatások mint komplex állami feladatellátási kötelmek egy társadalom tagjainak életminôségét közvetlenül képesek befolyásolni a közösségi javak hozzáférhetôsége, felhasználhatósága révén. Szerepük a 19. század második felében kezdett az államigazgatáson belül kulcsfontosságúvá válni, amikor egyre több magánszolgáltatást emeltek át a versenypiaci múködésből a közigazgatási jog által szabályozott keretek közé.

A közszolgáltatások fogalmának magyarázata tekintetében a közigazgatási tudományokból érdemes kiindulni, de amikor ezt tesszük, rögtön azzal találjuk szemben magunkat, hogy a közigazgatás körén belül is különbözô megközelítések 
léteznek. A közgazdaság-tudomány fókuszában méretgazdaságossági szempontok állnak, míg a szociológia a közszükséglet, illetve a társadalmi jólét maximumát helyezi középpontba. A közigazgatás-tudomány az igazgatási feladatokra koncentrál, míg a jogtudomány - természetébôl fakadóan - a jogi szabályozottságot, illetve lefedettséget vizsgálja.

A fogalmi determinációt tartalmi szempontból Hoffman három szinten határozza meg, amely a legtágabb értelmezéstôl a legszúkebb lehatárolásig terjed. Legtágabb értelmezésbe sorolható minden olyan állami szolgáltatás, amelyet az állampolgárok alanyi jogon (adófizetési kötelmükért cserébe) részben vagy teljes egészében térítésmentesen igénybe vehetnek (pl. törvényhozás, bûnüldözési tevékenység stb.). A szúkebb értelmezés szerint, ezek az állampolgárok széles körének nyújtanak ellátást, és „nem minôsülnek egyoldalú, közhatalmi aktusnak". A legszúkebb értelemben vett közszolgáltatások közé sorolja azokat, amelyek esetében az állam - vagy a vele közszolgáltatási szerzôdést kötố jogi személy - tényleges, személyre szabott szolgáltatást nyújt (Hoffman, 2006). Utóbbiakat valamilyen jogosultsági vagy kedvezményezetti alapon veheti igénybe az állampolgár. Mindhárom kategória esetében egyaránt gyakori a veszteségfinanszírozás. Ennek értelmében az állami feladatellátást magára vállaló gazdasági társaság közvetlenül a szolgáltatáshoz kapcsolható veszteségét az állam köteles megtéríteni a szolgáltatónak. A veszteségfinanszírozás megítélésekor különbséget kell tennünk a különbözó ágazatokba tartozó közszolgáltatások között, amelyeknek sajátosságai természetüknél fogva határozzák meg a feladatellátási kötelezettséget átvállaló finanszírozási kereteket. Értelemszerúen más-más kategóriába sorolható az egészségügy és a közösségi közlekedés, mert míg elóbbi az emberi erőforrás minôségéhez szorosabban kötódik, addig utóbbinak a gazdasági haszna általában könynyebben számszerúsíthetố.

Hozzáférés szempontjából a közösségi jószágok csoportosítása szofisztikáltabban elvégezhetô, hiszen léteznek olyan, a közösséget kiszolgáló, társadalmi igényeket kielégító szolgáltatások, amelyek fogyasztásából a jogi személyek sem zárhatók ki. Ezek az ún. tiszta közjavak, mint például a közösségi színterek, parkok stb. Ezzel szemben a vegyes közjavak esetében bizonyos fogyasztói réteg kizárása túl költséges lenne, így a rendszerben megjelennek a potyautasok, akik ellátása a társadalom számára evidenciává vált. Ebbe a körbe tartozik például a szociális segélyrendszer összes eleme. A vegyes közjavak esetében elmondható tehát, hogy abba azok a nem tisztán versenypiaci kategóriájú szolgáltatások tehetôk, amelyek jellegüket tekintve társadalmi, szociálpolitikai vagy más célrendszer alapján szervezôdnek. Ez egyben felveti az elszámolhatóság kérdését, illetve az átláthatatlanság disszonanciáját, és magában hordozza a témával kapcsolatos döntések nehézségét. Ezt a kettôsséget egyfelôl a támogatások megítélése, a tevékenységek hatékonysági pressziója, másfelól a társadalmi-gazdasági szempontú minôségi célkitúzések jelentik.

Az állami feladatellátási kötelezettség tekintetében elmondható, hogy minden közszolgáltatásnak minôsül, amit a jogalkotó meghatározott eljárás keretében közszolgáltatásnak minősít. Fontos ismérv, hogy minden állampolgárnak alkotmányos alapjoga a közjavakhoz való hozzáférés, amelynek keretében az állam 


\section{Tudományos múhely}

gazdasági szerepet vállal többek között szociális, egészségügyi, oktatási, közlekedési, kulturális, energetikai területen. A kapcsolódó feladatellátást az állam egyetemleges közszolgáltatási szerzódés keretén belül átruházhatja gazdasági társaságokra, amelyek kötelesek a szerzôdéses feladatuk maradéktalan és kifogástalan ellátására, amelyért a piaci ár és a közszolgáltatásból fakadó és nyújtandó kedvezmények közötti árkülönbözetet, illetve az ebból fakadó gazdasági veszteséget az állam a közszolgáltatási szerzôdésben meghatározott feltételek szerint köteles megtéríteni. A közszolgáltatás nyújtása során az állam feladata - a szabályozó hatóságok közremúködésével - a piac szabályozása, a múködés ellenôrzése, a tevékenység finanszírozása.

A közszolgáltatások nem pusztán közvetett, hanem közvetlen módon is hozzájárulnak egy nemzetgazdaság vagy azon belül egy-egy térség gazdasági és humánpotenciáljához, és ezáltal versenyképességéhez. Ennek alapfeltételei a hatékony és gazdaságilag stabil (tehát fenntartható), a gazdaságot kiszolgáló múködés és a szolgáltatók közötti versenyhelyzet megteremtése. Ennek révén tisztul a piaci verseny, és javul a szolgáltatások minôsége és hatékonysága. Ennek szellemében érdemes azokra a szolgáltatásokra fókuszálni, amelyek a nemzetgazdaság szempontjából nagyobb volumenú erôforrásokat kötnek le, és hatékonyság szempontjából jelentôs források allokációját kívánják. Továbbá azokra is hatványozott figyelmet kell fordítani, amelyek nemzetgazdasági szempontból stratégiai fontosságúak, és a nyitott vagy nyitásra váró piac miatt nemzetközi versenytársak belépésére számíthatnak. Utóbbi piacok megóvása azért is kiemelkedô fontosságú, mert egy-egy nemzet esetében általában hálózatias (gyakran egész országot lefedô) és generációkon átívelố teljesítményt manifesztáló (akár know-how-ban, akár infrastruktúrában megjelenô) teljesítményrôl van szó. Ugyancsak kiemelt figyelmet érdemelnek azok a közszolgáltatások, ahol a foglalkoztatottság nagy, tehát jelentôs munkaerôpiaci kitettséggel rendelkeznek.

A közszolgáltatásokba történô beruházás azért is megtérül, mert a minôségi közszolgáltatások több szinten is hozzájárulnak a területi versenyképességhez:

- A helyi önkormányzatok adó- és egyéb kedvezmények formájában megteremtik a lehetôséget a betelepülố tốke vagy a meglévố vállalkozások számára a hatékonyabb múködésre, ami elôsegíti azok magasabb foglalkoztatottsági mutatókkal, illetve magasabb termelékenységgel - azaz nagyobb iparúzésiadó-alappal történố múködését.

- A térségekben múködô vállalkozások és a lakónépesség számára nyújtott magasabb hozzáadott érték szélesebb múködési terület és hozzáférhetôség révén segíti elố az érintettek versenyképességét az adott lokációban és nemzet(közi) gazdasági színtéren egyaránt.

- Idesorolható minden olyan közszolgáltatás, amely hat a nemzetközi versenyben való megmérettetés eredményességére: ilyen például a logisztikai és szállítmányozási piac valamennyi résztvevôje, illetve a felsôoktatási intézmények mindegyike (Kiss, 2011).

Figyelembe véve a közszolgáltatások erôforrásigényét (illetve az ebből fakadó munkaerópiaci hatásokat), és azt a tényt, hogy másodlagos (kiszolgáló) szerepük révén nagymértékben szolgálják a nemzetgazdaság versenyképességének egészét, a rájuk való fókuszálás indokolt. 
A NEMZETGAZDASÁG BELSỐ ERÔFORRÁSAI

$\mathrm{Az}$ endogén (belsố tényezốkön alapuló) növekedési elmélet a területi versenyképességgel kapcsolatos kutatások fókuszpontját a régiók közötti összehasonlításokról a belsố területi kapacitások mérésére helyezi át. Teszi ezt abból a megfontolásból, hogy a belsố kapacitások, erôforrások együttmúködéssel és szinergiával történô alkalmazása produktívabb, mint a szétszórt támogatási rendszer, és ezt tükröznie kell a regionális versenyképesség vizsgálati szempontjainak, mérési módszereinek is.

Az elmélet szerint a térségek belsố erôforrásai közül a helyben meglévố gazdaságföldrajzi és „socialeconomic” adottságokat kell felismerni és hatékonyan mozgósítani a területi fejlôdés érdekében. Tömörebben: a területek kondícióinak meghatározó befolyása van a gazdasági tevékenységek jövedelmezôségére, illetve ezen keresztül a lokáció versenyképességére (Bodnár, 2013).

Meglátásunk szerint a számos kutató (Chapain-Clifton-Comunian, 2013; Capello, 2012) által képviselt irányvonal, amely a tudásból, illetve az innovációból eredezteti az endogén növekedést, csak akkor lehet igaz egy-egy konkrét lokáció esetében, ha ennek a tudásnak létezik munkaerópiaci szempontból releváns felvevôbázisa, illetve a keletkezett termékeknek, szolgáltatásoknak megfeleló piaca. Tehát csak addig létezhet az innovációalapú, tudásközpontú versenyképesség az adott térségben, amíg el nem éri a tudásalapon szervezôdött populáció létszáma azt a piachoz képest kritikus tömeget, ami vagy elvándorlást, vagy tevékenységáthelyezést eredményez. Még ha ez aggregált országos adatsorokban nem is jelenik meg, de bizonyos területekrôl elvándorlást indíthat meg, míg más, befogadó területeken fennáll annak a veszélye, hogy az adott gazdasági tevékenységhez kapcsolódó haszonból az érintett területi-közigazgatási egység nem vagy csak kismértékben részesül. Ezzel szemben a belsố tényezốs növekedéselmélet fejlesztéspolitikai szempontból fontos aspektusnak tartja a fenntarthatóság kérdéskörét, hiszen az emberi erôforrás és az infrastruktúra egyidejú fejlesztésétôl várja el, hogy - a multiplikátorhatásokon keresztül - fokozza a keresletet, illetve a termelékenység javítására legyen képes (Miklós-Molnár, 2012). Hasonló álláspontot képvisel Rechnitzer is, aki szerint a regionális potenciált az endogén források jellemzói determinálják (Rechnitzer, 2002).

A jelen tanulmány szerzôi a tốkepotenciált - azaz a rendelkezésre álló termelôbázisokat, illetve tốkét - az alábbi versenyképességi tényezôk szerint csoportosítják (1. táblázat).

A regionális kutatások számos esetben próbálják összefogni azokat a szerteágazó és komplex tényezóket, amelyek vizsgálatba vonása révén a térségek versenyképessége mérhetố. A területi tốke dimenzióinak hazai interpretációit vizsgálva (Jóna, 2013) látható, hogy a közjavak, illetve közszolgáltatások alacsony rivalizálás mellett vehetốk igénybe, de az eredeti területitốke-modell (Camagni-Capello, 2009) nem tér ki a közjavak és a versenyképesség kapcsolatának elemzésére, viszont axiómaként is értelmezhetô a közszolgáltatások hozzáférhetôségének és a lakónépesség versenyképességének kapcsolata. Ugyanis a térben koncentrálódó potenciál elszívja a perifériatérségekbôl a termelési tényezôket - amelyek közül leginkább mobil 
1. táblázat: A versenyképességi tényezôk és a közszolgáltatások kapcsolata

\begin{tabular}{|c|c|c|}
\hline & Tényezó megnevezése & Konceptualizálás \\
\hline I. & A munkaerô jellemzôi & $\begin{array}{l}\text { Exogén tényezô - de egyes kutatók endogén tényezôként } \\
\text { fogják fel - , ahol a hangsúly a munkaerôpiaci korösszetételen } \\
\text { és képzettségi szinten van. Itt hívjuk fel a figyelmet arra, hogy } \\
\text { az iskolarendszer fốként állami feladatellátási körbe tartozik, } \\
\text { tehát a közoktatási, szakképzési és felsôoktatási rendszerekhez } \\
\text { való hozzáférés közszolgáltatási aspektus. }\end{array}$ \\
\hline II. & $\begin{array}{l}\text { Infrastrukturális jel- } \\
\text { lemzók }\end{array}$ & $\begin{array}{l}\text { A térségben rendelkezésre álló - részint állami, részint ön- } \\
\text { kormányzati fenntartású vagy gondozásban lévố - területek } \\
\text { és felépítmények, amelyek gazdasági potenciált foglalnak } \\
\text { magukban. }\end{array}$ \\
\hline III. & Földrajzi helyzet & $\begin{array}{l}\text { Exogén változó, ahol a területi versenyképességre való hatás } \\
\text { adott, illetve amennyiben elônytelen, úgy ez csak fejlesztés- } \\
\text { politikai beavatkozással tompítható. (Ilyen intézkedés lehet } \\
\text { például a közlekedési infrastruktúra fejlesztése, kiemelt } \\
\text { beruházások stb.) }\end{array}$ \\
\hline IV. & $\begin{array}{l}\text { Szociokulturális } \\
\text { adottságok }\end{array}$ & $\begin{array}{l}\text { A tárgykör pénzben közvetlenül nem kifejezhetô, de mégis } \\
\text { olyan potenciált hordoz, aminek gazdasági vetülete is létezik. } \\
\text { Hatást gyakorol a terület népességmegtartó erejére, illetve } \\
\text { egy térség populációjának a munkához való hozzáállására. } \\
\text { Ennek ápolása és fejlesztése - nagyrészt - szintén az állami } \\
\text { feladatellátás körébe tartozik. }\end{array}$ \\
\hline V. & Piaci kapcsolatok & $\begin{array}{l}\text { Kereslet-kínálati tényezôk, amelyek a szinergikus piaci } \\
\text { mechanizmusokra és a fizetôképes keresletre építenek. Ide } \\
\text { sorolnánk be azokat az állami vagy önkormányzati kezde- } \\
\text { ményezéseket, amelyek ennek elôsegítését szolgálják (pl. } \\
\text { a versenyképesség fejlesztésére irányuló állami operatív } \\
\text { programok, inkubációs programok, települési vagy kistérségi } \\
\text { együttmúködések stb.). }\end{array}$ \\
\hline VI. & $\begin{array}{l}\text { Döntési-intézményi és } \\
\text { hatalmi rendszer }\end{array}$ & $\begin{array}{l}\text { A jogalkotás területi hatályát, illetve hatását hangsúlyozzák a } \\
\text { szerzốk, illetve az állampolgárok és vállalkozások ügyintézéssel } \\
\text { kapcsolatos kiszolgálását, a térségek komplex jogi környezetét } \\
\text { emelik be a tôkefogalomba. }\end{array}$ \\
\hline
\end{tabular}

Forrás: Saját szerkesztés

a humán erôforrás -, ami konzerválja az érintett területek gazdasági és humánpotenciáljának kedvezôtlen helyzetét. Ez törvényszerúen együtt jár a gazdaság szerkezetének tercierizálódásával, azonban települési szinten gondot okozhat a nagymértékú elvándorlás, de az is, hogy bizonyos néprétegek munkalehetôség, képzettség, kielégító jövedelem és lehe- tôségek hiányában a hátrányos helyzetú területeken rekednek (Kovács, 2016).

A térgazdaságtani értelemben vett erôkoncentrációs elméletek egyike a centrum-periféria modell (Wallerstein, 1983), amelyet számos hazai szerzố is feldolgozott. A centrum-periféria modellben a térnek két pólusa létezik (Nemes Nagy, 2009). Eszerint a centrum pozitív, 
nagy gazdasági és társadalmi pontenciált magában hordozó, azokat halmozó területi egység, tekintet nélkül a földrajzi értelemben vett elhelyezkedésétôl. Ezek karakterisztikáját befolyásolja a közszolgáltatások, közintézmények jelenléte, illetve azok hozzáférhetôségének intenzitása, ami leginkább a közlekedési infrastruktúra kiépítettségétôl függ.

Persze a területi egyenlótlenségek nem merülnek ki néhány dimenzió vagy indikátor elemzése által nyújtott válaszban, mert a szociális és gazdaságtani ismérvek együtt, egy idóben vannak jelen, és fejtik ki hatásukat a területi egyenlótlenségek vonatkozásában (Obádovics-Buder-Kulcsár, 2013). A szegénység nemcsak pénzügyi, anyagi síkon manifesztálódik, hanem emellett a közjavakhoz való hozzáférés szúkösségében is megjelenik. Utóbbi hatását értelemszerúen tompítja a gazdasági jólét, ami a közszolgáltatások hiányával ellentétes irányba hat. Mindez azt sejteti, hogy a centrum-periféria relációk markánsan meghatározzák a térgazdaságtani és demográfiai folyamatok jelenét és jövôjét, újraértelmezve ezzel egy adott térség közgazdaságtani helyzetét.

\section{TÉRELEMZÉS}

A térgazdaságtani szakirodalom a regionális versenyképességi vizsgálatok során az egy fôre jutó GDP-t mint eredményváltozót vizsgálja, és számos egyéb magyarázó változót figyelembe vesz a térségek versenyképességi rangsorolása során (Pénzes, 2013). Ezt a módszertant elôszeretettel alkalmazzák a NUTS3-as vagy az alatti területi egységekre is, miközben a terület lakónépességének jóllétére kiható soft tényezóket nem tartják szem előtt. Tehát érdekes kutatói kérdés, hogy mi- ként lehetne javítani a térségek jóllétét, gazdaságát és foglalkoztatottságát a közszolgáltatások javításán keresztül, és viszont: a gazdaság térbeli koncentrációja és a humán erôforrás jellemzói miként hatnak vissza a közszolgáltatási igényre, valamint annak jellemzőire; de feltárandó a lakónépesség jóllétének gazdaságra gyakorolt hatása is.

A fentiek szellemében célkitúzésünk annak a kérdéskörnek a minél átfogóbb vizsgálata, hogy mennyire jár együtt, vagy éppen mennyire különül el az egyes települések esetében a közszolgáltatások, a humán adottságok, illetve a gazdasági potenciál térbeli koncentrációja a különbözô területi determinációk mellett. Ennek megfelelôen a célmeghatározást követố elsố lépésként kigyújtöttünk valamennyi olyan általunk elérhetô változót (elsô körben csupán tartalmi szempontok alapján), amelyek jellemezhetik és differenciálhatják az egyes területi egységeket társadalmi-gazdasági helyzetük és közszolgáltatásokkal való ellátottságuk szerint - a lehetô legtágabb értelemben (lásd 1. ábra). Elôzetesen azon szempontból kategorizáltuk, hogy azok meglévô, a településvezetés és közszolgáltatás-szervezés szempontjából külsố adottságként kezelhetô (gazdasági, foglalkoztatottsági vagy demográfiai) szempontok, vagy az ágazati, illetve területfejlesztési politika által is közvetlenül befolyásolhatók (infrastruktúra-hálózati közszolgáltatások, szociális ellátás, oktatás, egészségügy, kultúra és közigazgatás). Az ágazati megközelítés megfelelô kiindulópontnak tûnt.

Elsố körben 475, települési szinten is elérhetố mutató felelt meg ennek a szempontnak. Mivel ez az adattömeg hatalmas, vagy képi megjelenítésre alkalmatlan, adatredukciós módszerre (faktor- vagy 


\section{Tudományos múhely}

fốkomponens-elemzésre) volt szükség (Székelyi-Barna, 2002). Így az egymással összefüggó mutatókból kisebb számú faktort nyerünk, amelyek alapján képesek leszünk a települési szintú adatok típusainak és ezzel együtt jellemzô változóértékeinek a meghatározására, feltárására is a klaszteranalízis segítségével. Ha az alapvetô problémákat és azok összefüggéseit ezzel a módszerrel feltártuk, véleményünk szerint akkor lesz lehetôségünk a továbbiakban ezek, illetve az adott település (majd térség) jellemzóit, a - jelen vizsgálat eredményében is tükrözôdô - településhierarchiát és az esetleges települések közötti feladatmegosztást (specializációt) is figyelembe véve, közszolgáltatás-fejlesztési javaslatok megfogalmazására.

Figyelembe vettük, hogy a faktor/ fókomponens- és klaszteranalízisbe kizárólag magas mérési szintú változók kerülhetnek (Sajtos-Mitev, 2007), illetve kiküszöböltük az igen szélsôséges vagy véletlenszerú eloszlást követố változók nagy részét, így az adatredukciót 177 változó mentén kezdtük futtatni. (A csupán módszertani okokból kiesett, de nyilvánvalóan nagy kifejezôerôvel bíró változókat területi egységenként is besoroltuk, így a statisztikai vizsgálat eredményei ezekkel kontextusában - például járásonként, megyénként, agglomerációnként - is kiegészíthetôek a késôbbi kutatások során.)

A nagyszámú változó vizsgálata mellett - a területi kiegyenlítődés és az esélyegyenlôség szempontjait is szem elôtt tartva - célunk volt továbbá az is, hogy figyelmünk a legkisebb településre is kiterjedjen, így a vizsgálat egységeiként Magyarország 3154 vidéki települését választottuk. A kiugró adatok elkerülése érdekében a jelen vizsgálat nem terjed ki Budapestre, amit az is indokol, hogy a fóváros, illetve a Kö-
zép-Magyarország régió már a kétezres években elérte az Európai Unió fejlettségi átlagát, például az egy fớre esô, vásárlóerô-paritáson mért GDP tekintetében. (Emiatt számos területi kiegyenlítódést célzó fejlesztési forrásra sem pályázhat már, de feltételezhetjük azt is, hogy a gazdasági infrastruktúra és a gazdaság fejlôdését elôsegító intézményrendszer, mint például startupokat támogató alapok, pénzügyi szolgáltatások, oktatás-kutatás és az egyéb, közvetlenül üzleti szolgáltatások már vannak annyira fejlettek, hogy a gazdaság fejlốdése további állami beavatkozás nélkül is kedvezố irányt vesz.) A fốváros a legtöbb gazdasági jellemzô mentén annyira eltér a vidéktôl, hogy annak fejlódése külön vizsgálat tárgyát kellene hogy képezze. Pest megyét azonban nem vettük ki a vizsgálatból, tekintve, hogy a terület maga is heterogén (Tipold et al., 2015). A fốvárost leszámítva az egyéb (közepes és nagy-) városok vizsgálatban maradását indokolja egyrészt a vizsgálat célja, amely nem csak és nem elsôsorban a leghátrányosabb helyzetú vagy a legkisebb településekre terjed ki.

A városok, községek, kistelepülések, aprófalvak összehasonlíthatóságának problémáját nagyrészt népességszámra arányosított viszonyszámok képzésével és használatával küszöböltük ki. Mindemellett magát a népességszámot nem vontuk be a fö́komponens- és klaszterelemzésbe. (Ennek ellenére - mint látni fogjuk - a kialakult csoportok népességszám alapján is igen jól körülírhatók.) Ezzel az volt a célunk, hogy érzékeltessük, hogy melyek azok a gazdasági jellemzók vagy szolgáltatások, amelyek a népességnél is jobban koncentrálódnak a térben, és ezáltal hol teremtôdik meg a lehetôsége a további agglomerációs elônyök megjelenésének és tovagyưrúzésének, és hogy ezzel szemben hol keletke- 
zik vákuum, ellátatlan néptömegek vagy szegény térségek, ahol szolgáltatás-, illetve gazdaságfejlesztésre, vagy legalább a közeli központok elérhetôségének biztosítására van szükség. (A módszer hátránya viszont az, hogy a legkisebb, elsôsorban 100 fó alatti települések esetében igencsak felfelé torzíthatnak ezek a mérôszámok, amenynyiben bizonyos típusú szolgáltatásból vagy méretú vállalkozásból egy vagy néhány jelen van a településen.)

\section{A vizsGálat EREDMÉNYEI}

Az adatredukció tekintetében a fốkomponens-elemzés bizonyult hatásosnak. A vizsgálat többszöri lefuttatása után és a nem megfelelóen aggregálható mutatóktól lépésenként megszabadulva 101 megórzött, 8 fókomponensre megfelelóen illeszkedô változó maradt meg, és az így keletkezett fókomponensek az eredeti változók információtartalmának összesen 59,5\%-át ôrizték meg, aminek a magyarázóértékét elfogadtuk. A kialakult fókomponensek azonban nem elsốsorban az elôzetes, külsô-belsố tényezóket vagy ágazati tagozódást követték, hanem azok sokkal inkább függenek össze a településhierarchiával, illetve az adott jellemzó vagy szolgáltatás által érintett korcsoport vagy gazdasági tevékenység adott településen való meglétével vagy hiányával. Például az oktatás ágazata három különbözó fókomponensre „esett szét”: alapfokú oktatásra (amelybe bekerültek a körzeti szintú egészségügyi ellátások is), középfokú, valamint felsôoktatásra. Ez egyrészt következik a vizsgálat módjából, de egyben rávilágít a területi szemlélet szükségességére is. Ellenben a „Szegénység és a rászorulókat támogató intézményrendszer" fốkomponens nagyban érinti a munkanélküliséggel kapcsolatos és demográfiai tényezóket, de számos infrastrukturális elemet és szinte a teljes szociális ellátást is felöleli (1. ábra).

\section{1. ábra: Fökomponensek az elözetes koncepció tükrében}

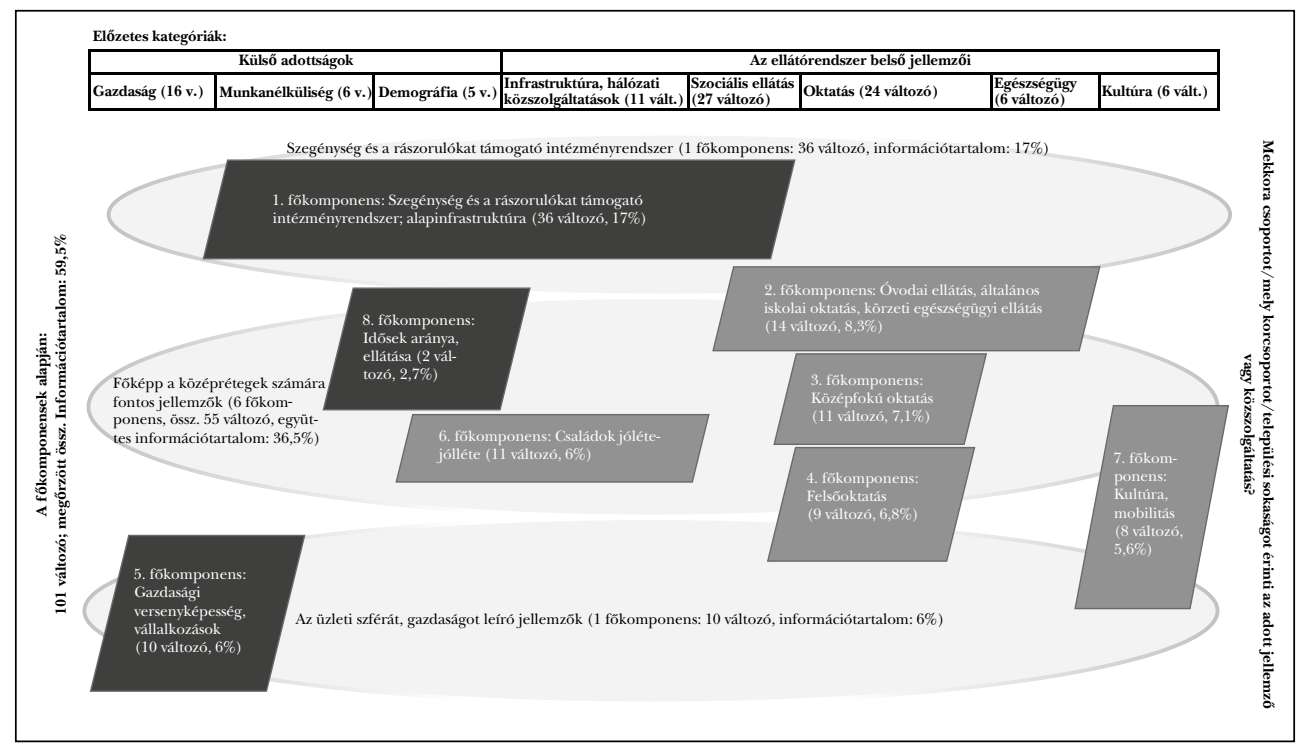

Forrás: Saját vizsgálat a KSH (2015, 2017) és a TEIR 2017-es adatai alapján 
A nyolc, viszonylag jól interpretálható fókomponens már elég jól kezelhetô ahhoz, hogy azokon klaszteranalízist hajtsunk végre a települések kategóriákba sorolása és ezek mentén történố nyolcdimenziós jellemzése érdekében. Tekintettel a viszonylag nagy adatállományra és még így is meglehetôsen sok dimenzióra, ${ }^{4}$ az iterációs K-Means Cluster-eljárást alkalmaztuk az SPSS-programcsomag segítségével (Obádovics, 2009). A módszer kiszámítja a dimenziók magpontjait, és az azokkal kapcsolt elemeket mindaddig rotálja, amíg a klaszterközéppontok nem stabilizálódnak.

\section{2. táblázat: A fókomponensek és az általuk összefogott változók}

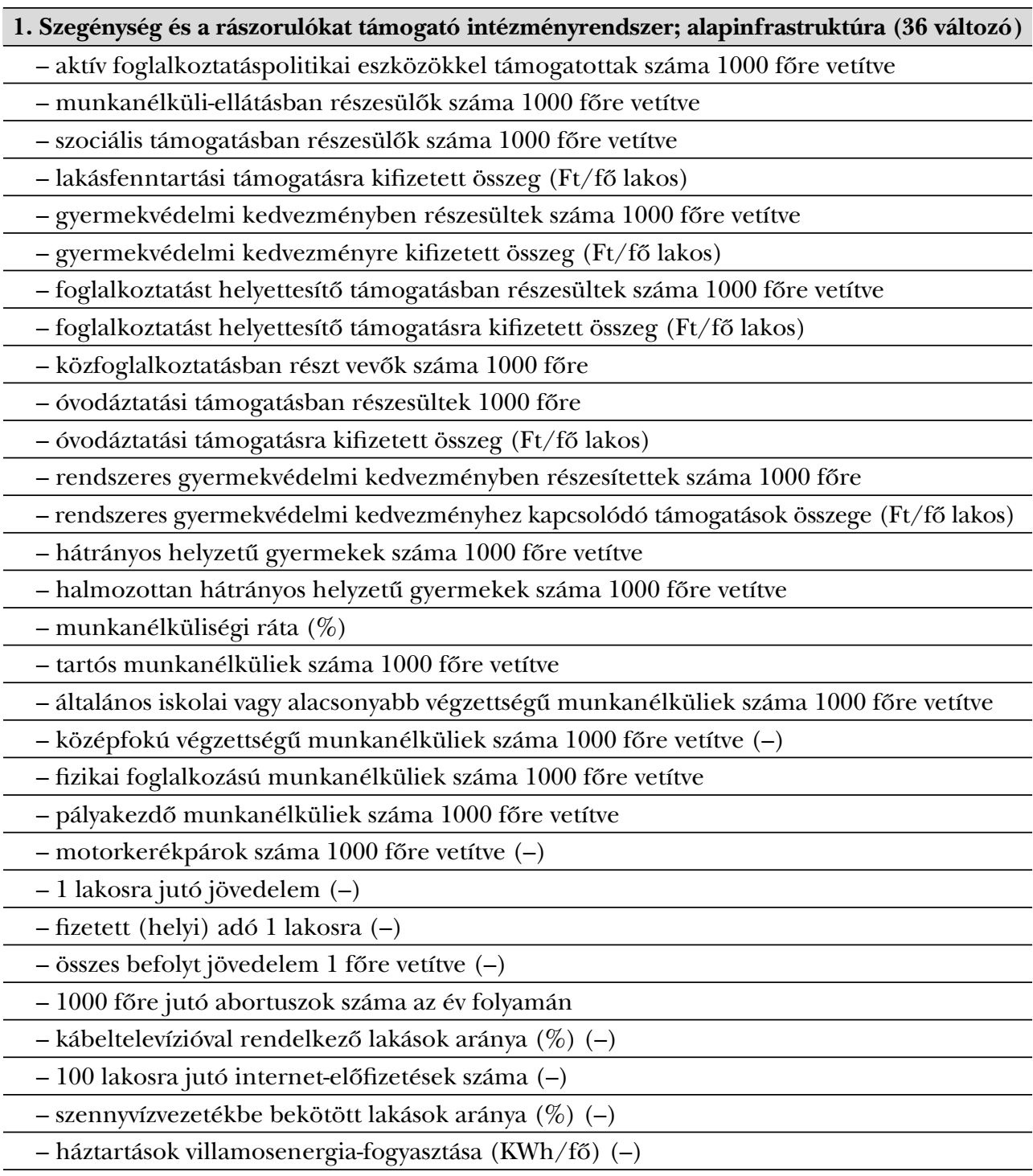




\section{Tudományos mühely}

- gázfogyasztó háztartások száma 100 lakásra vetítve (-)

- internettel rendelkezó általános iskolák aránya (\%)

- 1 általános iskolára jutó számítógépek száma

- 1 középfokú oktatási intézményre jutó számítógépek száma

- 100 före jutó telefonvonalak száma

- könyvtárak 1000 főre jutó száma

\section{2. Óvodai ellátás, általános iskolai oktatás, körzeti egészségügyi ellátás (14 változó)}

- 1000 före jutó szakápoló

- 1000 fốre jutó védônố

- 1000 lakosra jutó házi és gyermekorvosok száma

- 1000 lakosra jutó háziorvosok száma

- óvodai férôhelyek kihasználtsága (\%)

- 1000 fốre jutó óvodai férôhelyek száma

- 1000 fớre jutó óvodás gyermekek száma

- 100 óvodásra jutó óvópedagógusok száma

- 100 tanulóra jutó általános iskolai osztálytermek száma

- általános iskolák száma 1000 fốre vetítve

- általános iskolai tanulók száma 1000 fốre vetítve

- általános iskolai pedagógusok 100 tanulóra vetített száma

- napközi ellátásban részesüló általános iskolai tanulók száma 1000 fốre vetítve

- bejáró általános iskolások aránya (\%)

\section{Középfokú oktatás (11 változó)}

- középiskolák száma 1000 fŏ́re

- középfokú oktatási intézményben tanulók száma 1000 fốre

- gimnáziumi tanulók száma 1000 före

- szakközépiskolai tanulók száma 1000 fốre

- sikeres érettségi vizsgát tettek 100 diákra jutó száma

- 100 diákra jutó középiskolai pedagógus száma

- szakiskolák száma 1000 fớre vetítve

- középfokú oktatási intézmények száma 1000 fốre vetítve

- szakiskolai tanulók száma 1000 fốre

- 100 fő́re jutó szakiskolai tanárok száma

- bejárók aránya a középfokú oktatásban (\%)

\section{Felsôoktatás (9 változó)}

- nappali tagozaton felsôfokú szakképzésen részt vevô diákok száma 1000 fốre vetítve

- levelezô tagozaton felsôfokú szakképzésen részt vevô diákok száma 1000 fớre vetítve

- felsőfokú szakképzésen részt vevô diákok száma 1000 fớre vetítve

- nappali tagozatos egyetemi és fóiskolai hallgatók száma 1000 fớre vetítve

- levelezố tagozatos egyetemi és fốiskolai hallgatók száma 1000 fốre vetítve 


\section{Tudományos mühely}

- egyetemi és fôiskolai hallgatók száma 1000 fốre vetítve

- egyéb (nem települési) könyvtárból kölcsönzött könyvek éves száma 1 fŏre vetítve

- egyéb (nem települési) könyvtárba beíratkozottak száma 1000 fő́re vetítve

- kollégiumban lakó felsôoktatási hallgatók száma 1000 fớre vetítve

\section{Gazdasági versenyképesség, vállalkozások (10 változó)}

- legalább 10 fớt foglalkoztató regisztrált vállalkozások 1000 fốre jutó száma

- 1000 fốre jutó tehergépjármúvek száma

-1 fớre jutó hozzáadott érték (Ft)

- 1 fốre jutó bérköltség (Ft)

- 1 fớre jutó kibocsátás $(\mathrm{Ft})$

-1 fốre jutó fizetett adó (Ft)

- a vállalkozások 1 lakosra vetített bevétele $(\mathrm{Ft})$

- múködő vállalkozások 1000 fốre jutó száma

- múködô társas vállalkozások 1000 fốre jutó száma

- legalább 10 fốt foglalkoztató társas vállalkozások 1000 fốre jutó száma

6. Családok jóléte, jólléte és az ehhez kapcsolódó közszolgáltatások (11 változó)

- települési önkormányzat által kiépített út hossza $\left(\mathrm{m} / \mathrm{km}^{2}\right)$

- gyermekorvos által ellátott esetek száma a 14 éves kor alatti gyermekek számára vetítve

- 1000 gyermekre jutó gyermekorvosok száma

- idôskorúak nappali intézményeinek kihasználtsága (\%)

- szociális intézmények kihasználtsága (\%)

- bölcsôdei férôhelyek 1000 fốre jutó aránya

- bölcsôdés gyermekek 1000 fốre jutó aránya

- bölcsốdei férôhelyek kihasználtsága (\%)

- 100 bölcsốdésre jutó nevelốk száma

- bölcsốdék száma 1000 fốre vetítve

- népsúrúség (fö $/ \mathrm{km}^{2}$ )

\section{Kultúra, mobilitás (8 változó)}

- 100 fốre jutó lakások száma

- települési könyvtárból kikölcsönzött könyvek száma 1 lakosra

- települési könyvtárba beiratkozottak 100 fóre jutó száma

- közmúvelôdési intézmények száma 1000 lakosra

- civil, nonprofit szervezetek 1000 lakosra vetített száma

- (helyi) adót fizetố népesség aránya (\%)

- teljes vándorlási különbözet (ezrelék) (-)

- állandó vándorlási különbözet (ezrelék) (-)

\section{Idôsek aránya, ellátása ( 2 változó)}

- nyugdíjban részesültek 1000 lakosra vetített száma

- 65 éven felüliek aránya

Forrás: Saját vizsgálat a KSH (2015, 2017) és a TEIR 2017-es adatai alapján 


\section{Tudományos múhely}

A kezdeti iterációk során világossá vált (akár több, akár kevesebb klaszterszámot előzetesen meghatározva), hogy bizonyos települések jellemzőit, kiugró értékeit közelebbrôl is szemügyre kell venni, mert bizonyos klaszterek elemszáma túl kicsinek tûnt. Hétklaszteres bontásban külön klasztert alkotott például a mindössze 12 fôt számláló Tornabarakony, ahol a meglévố infrastrukturális létesítmények mindössze ilyen kevés fốre mint vetítési alapra oszlottak el, és ezért irreálisan magasnak túntek. De az elvándorlás is szélsôségesen magas értéket vett fel a településen a 2015-ös évben. Következésképpen ez a klaszter „kimagasló jólét” képét mutatta mind az 1. (szegénység, illetve annak hiánya), mind pedig a 7. (kultúra, mobilitás) fôkomponens mentén, ami nyilvánvalóan nem tükrözi a valóságot. Kirajzolódott egy olyan hatelemú, többnyire kistelepüléseket (Tésa, Óbudavár, Teresztenye, Komlóska, Újlengyel és Nagypáli) tartalmazó klaszter is, amelynek elemei az 5. fôkomponens, a gazdasági versenyképesség, vállalkozások dimenziója mentén mutattak kimagaslóan jó értékeket, míg a többi dimenzió ezt nem indokolta. Néhol felmerül az a gyanú, hogy bizonyos vállalkozásokat csak az alacsony kulcsú vagy nem lévô helyi adó miatt jelentettek be az adott településre, de valójában nem itt van a vállalat múködésének központja. Megvizsgálva a településekhez tartozó mért mutatóértékeket, azok elhelyezkedését és a róluk elérhetô egyéb információkat, az elôbbi négy települést és Tornabarakonyt elhagyva megismételtük a vizsgálatot. Azonban Újlengyel és Nagypáli az így módosított klaszterelemzésben is külön csoportot alkotott, így végül ezeket is mellőztük. Mivel a fentiek Magyarország 3155 településéból csak néhányat érintenek, viszont velük együtt rendkívül ellentmondásos, nyilvánvalóan téves klaszterstruktúra alakulna ki, az érintett összesen 7 települést kizártuk a vizsgálatból. ${ }^{5}$

A 3147 települést felölelő, 6 csoportból álló klaszterstruktúra, amely statisztikailag is megállja a helyét (2. táblázat), már értelmezhetô a magyar települések rendszerében és az azokat leíró fókomponensekben tömörített információtartalom fényében.

A varianciaanalízisból kiderül, hogy a klaszterek ténylegesen szignifikánsan, markánsan elkülönülnek egymástól az azokat alkotó változók (fókomponensek) mentén (Székelyi-Barna, 2002), így a települések valós csoportokba tömörülnek. Azonban a különbözô fókomponensek igen eltérố mértékben járulnak hozzá a klaszterek egymástól történô elkülönüléséhez: az F-statisztika értéke nagyságrendileg alacsonyabb az 1. (szegénység és a rászorulókat támogató intézményrendszer; alapinfrastruktúra), az 5. (gazdasági versenyképesség, vállalkozások) és a 8 . (idôsek aránya, ellátása) fốkomponens esetében. A települési adatsorok tükrében ez nem is lehet másképp, hiszen ezek nagyrészt olyan demográfiai vagy gazdasági jellemzókből állnak, amelyek valamilyen értéket minden magyarországi település esetén felvesznek (a kiinduló koncepcióban ezek voltak a „külsố adottságok"), míg a többi fôkomponensben tömörülő közszolgáltatások egy nagy része csak bizonyos, az adott (al)központi funkcióval rendelkezô településeken találhatók meg, a többi településen pedig nulla az egyes változók értéke. Ez utóbbiak alkalmasabbak a típusképzésre, a közszolgáltatások szintjeinek és ezáltal a településhierarchia megragadására. 


\section{Tudományos múhely}

3. táblázat: A klaszteranalizis ellenôrzése egyutas varianciaanalizissel

\begin{tabular}{|c|c|c|c|c|c|c|}
\hline \multirow{2}{*}{ Fókomponens } & \multicolumn{2}{|c|}{ Klaszter } & \multicolumn{2}{|c|}{ Hiba } & \multirow[t]{2}{*}{ F érték } & \multirow[t]{2}{*}{$\begin{array}{c}\text { Szignifi- } \\
\text { kancia }\end{array}$} \\
\hline & $\begin{array}{l}\text { Varian- } \\
\text { cia }\end{array}$ & $\begin{array}{c}\text { Szab. } \\
\text { fok }\end{array}$ & $\begin{array}{l}\text { Varian- } \\
\text { cia }\end{array}$ & $\begin{array}{c}\text { Szab. } \\
\text { fok }\end{array}$ & & \\
\hline $\begin{array}{l}\text { 1. Szegénység, szoc. támogató } \\
\text { rendszer; alap-infrastruktúra }\end{array}$ & 7,54 & 5 & 0,99 & 3141 & 7,61 & 0 \\
\hline $\begin{array}{l}\text { 2. Óvodai ellátás, általános isko- } \\
\text { lai oktatás, körzeti eü. ellátás }\end{array}$ & 474,63 & 5 & 0,24 & 3141 & 1976,15 & 0 \\
\hline 3. Középfokú oktatás & 445,85 & 5 & 0,29 & 3141 & 1518,50 & 0 \\
\hline 4. Felsôoktatás & 500,63 & 5 & 0,21 & 3141 & 2422,18 & 0 \\
\hline $\begin{array}{l}\text { 5. Gazdasági versenyképesség, } \\
\text { vállalkozások }\end{array}$ & 3,22 & 5 & 0,28 & 3141 & 11,46 & 0 \\
\hline 6. Családok jóléte, jólléte & 398,61 & 5 & 0,37 & 3141 & 1087,44 & 0 \\
\hline 7. Kultúra, mobilitás & 184,59 & 5 & 0,36 & 3141 & 518,78 & 0 \\
\hline 8. Idôsek aránya, ellátása & 16,36 & 5 & 0,96 & 3141 & 17,10 & 0 \\
\hline
\end{tabular}

Forrás: Saját szerkesztés

4. táblázat: A kialakult végsố klaszterközpontok elhelyezkedése a fôkomponensek által meghatározott térben - az egyes klaszterek jellemzöi

\begin{tabular}{l|r|r|r|r|r|r}
\hline \multicolumn{1}{c|}{ „Faktortér": 6 klaszter a 8 dimenziós térben } & \multicolumn{7}{c}{ Klaszterek } \\
\hline \multicolumn{1}{c|}{ Fókonensek } & $\mathbf{1}$ & $\mathbf{2}$ & $\mathbf{3}$ & $\mathbf{4}$ & $\mathbf{5}$ & $\mathbf{6}$ \\
\hline $\begin{array}{l}\text { 1. Szegénység, szoc. támogató rendszer; } \\
\text { alap-infrastruktúra }\end{array}$ & $-0,34$ & $-0,20$ & $-0,27$ & 0,00 & 0,09 & 0,11 \\
\hline $\begin{array}{l}\text { 2. Óvodai ellátás, általános iskolai oktatás, } \\
\text { körzeti eü. ellátás }\end{array}$ & 0,10 & 0,21 & 0,24 & 0,80 & $-1,09$ & $-1,00$ \\
\hline 3. Középfokú oktatás & 1,14 & 3,06 & $-0,50$ & $-0,25$ & $-0,17$ & $-0,13$ \\
\hline 4. Felsốoktatás & 13,31 & $-0,13$ & $-0,27$ & $-0,03$ & $-0,04$ & $-0,04$ \\
\hline 5. Gazdasági versenyképesség, vállalkozások & 0,16 & 0,06 & 0,06 & $-0,05$ & $-0,08$ & 0,27 \\
\hline 6. Családok jóléte, jólléte & 0,74 & 0,94 & 2,60 & $-0,32$ & $-0,29$ & $-0,16$ \\
\hline 7. Kultúra, mobilitás & 0,04 & $-0,01$ & $-0,16$ & $-0,15$ & $-0,06$ & 2,97 \\
\hline 8. Idósek aránya, ellátása & $-0,05$ & $-0,02$ & 0,08 & 0,01 & 0,05 & $-0,88$ \\
\hline
\end{tabular}

Forrás: Saját szerkesztés

A kapott eredmények értelmezésében segítséget nyújtott az egyes fókomponensváltozók eloszlásának hisztogramos szemléltetése és elemzése, valamint klaszterenként általunk ismert példatelepülések beazonosítása, továbbá az eredeti (még nem standardizált) változók néhány településenkén- ti értékének vizsgálata is. A legfóbb ilyen változó a népességszám volt, amely mentén elég jelentôsen eltérnek az egyes klaszterek annak ellenére, hogy ez a mutató sem a fókomponens-, sem pedig a klaszterelemzésben nem szerepelt. A kialakult 6 klaszter a következôképpen interpretálható: 
5. táblázat: Az egyes klaszterekbe tartozó települések száma és az eredmények értelmezése

\begin{tabular}{|c|c|c|c|c|}
\hline Klaszter neve & $\begin{array}{l}\text { Telepü- } \\
\text { lések } \\
\text { száma }\end{array}$ & $\begin{array}{c}\text { Jellemzó } \\
\text { népességszám }\end{array}$ & $\begin{array}{c}\text { Közszolgáltatások jel- } \\
\text { lemzői }\end{array}$ & $\begin{array}{l}\text { A gazdaság és a tár- } \\
\text { sadalom jellemzói }\end{array}$ \\
\hline $\begin{array}{l}\text { 1. Felsôoktatás ál- } \\
\text { tal meghatáro-zott } \\
\text { települések }\end{array}$ & 14 & $\begin{array}{l}\text { Eltérố } \\
\text { népesség- } \\
\text { számú váro- } \\
\text { sok }\end{array}$ & $\begin{array}{l}\text { Mind az alap-, közép- és } \\
\text { felsőfokú intézmények- } \\
\text { kel, mind egyéb közszol- } \\
\text { gáltatásokkal jól ellátott } \\
\text { települések. }\end{array}$ & $\begin{array}{l}\text { Nagyszámú } \\
\text { vállalkozás, erôs } \\
\text { gazdaság, magas } \\
\text { hozzáadott érték }\end{array}$ \\
\hline $\begin{array}{l}\text { 2. A viszonylagos } \\
\text { jólét gazdaságilag } \\
\text { stabil nagyközsé- } \\
\text { gei, városai }\end{array}$ & 217 & $\begin{array}{l}\text { Néhány ezer } \\
\text { footool } 120 \text { ezer } \\
\text { fooig }\end{array}$ & $\begin{array}{l}\text { Alap- és középfokú } \\
\text { okatással és álalánosabb } \\
\text { jellegú szolgáltatásokkal } \\
\text { jól ellátott, de a felsôok- } \\
\text { tatás nem meghatározó. }\end{array}$ & $\begin{array}{l}\text { Általában viszony- } \\
\text { lag fejlett gazdaság, } \\
\text { a települések kö- } \\
\text { zött mezógazdasági } \\
\text { és ipari központok } \\
\text { is megtalálhatók. }\end{array}$ \\
\hline $\begin{array}{l}\text { 3. Viszonylag } \\
\text { gazdag, de gyak- } \\
\text { ran elöregedó } \\
\text { nagyobb községek }\end{array}$ & 229 & $\begin{array}{l}\text { Általában } \\
\text { 1-11 ezer fó } \\
\text { között }\end{array}$ & $\begin{array}{l}\text { Alapfokú oktatással és } \\
\text { egészségügyi szolgáltatá- } \\
\text { sokkal jól ellátottak; kö- } \\
\text { zép- és felsôfokú oktatási } \\
\text { intézményekkel nem. }\end{array}$ & $\begin{array}{l}\text { Viszonylag feljett } \\
\text { gazdaság, amely } \\
\text { általában a me- } \\
\text { zôgazdasághoz és } \\
\text { feldolgozóiparhoz } \\
\text { kapcsolódik. }\end{array}$ \\
\hline $\begin{array}{l}\text { 4. Kevéssé tehetôs } \\
\text { nagyobb községek }\end{array}$ & 1494 & $\begin{array}{l}\text { Jellemzően } \\
1000 \text { vagy né- } \\
\text { hányezer fố }\end{array}$ & $\begin{array}{l}\text { Alapfokú oktatással és } \\
\text { egészségügyi szolgáltatá- } \\
\text { sokkal jól ellátottak; kö- } \\
\text { zép- és felsőfokú oktatási } \\
\text { intézményekkel nem. }\end{array}$ & $\begin{array}{l}\text { A vállalkozások } \\
\text { száma és gazdasági } \\
\text { ereje még a népes- } \\
\text { ségre vetítve is igen } \\
\text { csekély. }\end{array}$ \\
\hline $\begin{array}{l}\text { 5. Viszonylag } \\
\text { szegény, általában } \\
\text { elöregedő kistele- } \\
\text { pülések }\end{array}$ & 1093 & $\begin{array}{l}\text { Néhány száz } \\
\text { fố }\end{array}$ & $\begin{array}{l}\text { Alap- és középfokú intéz- } \\
\text { mények és körzeti jellegú } \\
\text { közszolgáltatások csak } \\
\text { ritkán fordulnak elő. }\end{array}$ & $\begin{array}{l}\text { A vállalkozások } \\
\text { száma és gazdasági } \\
\text { ereje még a né- } \\
\text { pességre vetítve is } \\
\text { rendkívül alacsony. }\end{array}$ \\
\hline $\begin{array}{l}\text { 6. Szegény, elván- } \\
\text { dorlással sújtott } \\
\text { törpefalvak }\end{array}$ & 100 & $\begin{array}{l}100 \text { fó vagy az } \\
\text { alatt }\end{array}$ & $\begin{array}{l}\text { Sem az oktatás, sem az } \\
\text { egyéb, alapvetô közszol- } \\
\text { gáltatások nem érhetôk } \\
\text { el helyben. }\end{array}$ & $\begin{array}{l}\text { Az } 1000 \text { foóre jutó } \\
\text { gazdasági aktivi- } \\
\text { tás mutatója az } \\
\text { alacsony népesség- } \\
\text { szám miatt torzít, } \\
\text { nem értelmezhetô. }\end{array}$ \\
\hline
\end{tabular}

Forrás: Saját szerkesztés

Jellemzői alapján az egyik legkedvezóbb helyzetú csoport az 1. klaszter, amely az elsôsorban a felsôoktatás által meghatározott településeket foglalja magában. Ez a csoport népességszám alapján eltérô településeket tartalmaz, de egy kivétellel valamennyi város. Elemszáma mindössze 14 település, de igen kedvezó jellemzôik alapján elkülönülnek a többi öt klasztertól, valamint több mint 1 millió fôs lakosságot foglalnak magukban, az ország népességének 10,5\%-át. Így van értelme elkülönült típusként tekinteni rájuk. Ezeken a településeken nemcsak 
a felsôoktatás és a kulturális javakkal való ellátottság kiemelkedôen magas, de itt találhatók a legnagyobb számú és arányú, legerôsebb vállalkozások is. Nemcsak az oktatás, de valamennyi közszolgáltatással való ellátottságuk nagyon jó, a szegénység jelenléte ebben a településcsoportban a legkevésbé meghatározó. Korstruktúrájuk is kedvezô. Ebbe a településcsoportba tartozik például Pécs, Veszprém, Szeged Gödölló és Keszthely. Mindez alátámasztani látszik azt, hogy a felsőfokú oktatás és a K+F jelenléte és kiemelkedố színvonala (az alapvetôbb közszolgáltatások megléte mellett) általában pozitív hatással van a gazdaság egészére. (Persze a fordított irányú okság is jelen van.)

A 2. klaszter a "Viszonylagos jólét gazdaságilag stabil nagyközségei, városai" nevet kapta. 217 település került ebbe a csoportba, de a viszonylag nagy (néhány ezer fốtôl 120 ezres nagyságrendig) településméret miatt ez az ország népességének 30,6\%-át, körülbelül 3 millió fốt foglal magában. A településcsoport fó jellemzóje az, hogy közszolgáltatásokkal igen jól ellátott - bár a felsôoktatás és a kultúra arányaiban kevéssé meghatározó, nem elsósorban ez az ágazat adja a települések arculatát. Az elsô fókomponens, a szegénység alacsony (negatív) és a 6., családok jóléte fókomponens magas értéke stabilitásra enged következtetni. A népesség korösszetétele általában fiatal, nagyobb mértékú elvándorlás nem jellemzó. Ebbe a településkörbe tartozik például Tatabánya, Székesfehérvár, Kecskemét, Nagykanizsa, Villány, Hévíz és Bácsalmás.

A 3. klaszterbe ezer-tízezer fôs nagyközségek és kisebb városok tartoznak, összesen 229 település. (Összlakosságuk 1,3 millió fố, az ország népességének 13,5\%-a, átlagos népességük 5700 fó.) Ezeknek a falvaknak, illetve kisvárosoknak a lakosságára viszonylagos jólét jellemzó mind az 1. (szegénység hiánya), mind pedig a 6 . (családok jóléte) fókomponens mentén. Elvándorlás itt sem jellemzô, azonban a korstruktúra kedvezôtlenebb, a népesség gyakran elöregedô. Igen kedvezốn alakul a gazdasági társaságok 1000 fốre jutó száma, illetve a gazdaság fejlettsége. Ami a helyben elérhetô közszolgáltatásokat illeti, a települések jellemzốen igen jól ellátottak alapfokú oktatási intézményekkel, bölcsôdékkel, körzeti egészségügyi szolgáltatásokkal, de a középfokú oktatás már ritkábban található meg helyben, a felsôfokú oktatás jelenléte nem jellemzô. Összegezve, az idetartozó településeket általában nem nevezhetjük hátrányos helyzetúnek. (Idesorolható például Sarkad, Soltvadkert, Mecseknádasd és Lengyeltóti, valamint Budapest agglomerációjának számos települése.)

Mind az 1., mind pedig a 6 . fókomponens értékei alapján kevéssé tehetôs népességgel rendelkeznek a 4. klaszterbe tartozó nagyobb községek és néhány kisebb város. A kultúra, mobilitás fốkomponense is meglehetôsen alacsony értékeket mutat. Az ezer-néhány ezer fốs 1494 település Magyarország népességének 23,5\%-át (2,3 millió fốt) tömöríti. A települések gazdasági ereje jellemzóen csekély. Bár ezek a települések alapfokú oktatással, körzeti egészségügyi ellátással és alap-infrastruktúrával még viszonylag jól ellátottak, de a közép- és felsôfokú oktatási intézmények jelenléte nem meghatározó. A településcsoportba tartozik például Dunaalmás, Gyermely, Tiszabecs és Kurd.

A fentieknél kisebb népességszámú, jellemzốen néhány száz fốs, viszonylag 


\section{Tudományos múhely}

szegény, általában elöregedô kistelepüléseket az 5. klaszter foglalja magában. A családok jóléte-jólléte faktor (amely tartalmazza a bölcsốdei ellátási és bizonyos szociális ellátási mutatókat is) értéke itt a legalacsonyabb, de a szegénységet kifejezô 1 . fớkomponens értéke is kedvezôtlen. Ezek a települések alap- és középfokú oktatással, körzeti egészségügyi és egyéb közszolgáltatásokkal csak igen ritkán ellátottak (a csoport csak egy-egy településén található általános, illetve középiskola). Gazdasági erejük rendkívül alacsony, arányaiban és számában is kevés vállalkozás van jelen. Bár jellemzố az idôs korstruktúra, de az elvándorlás kevéssé. Idesorolható például Kisbajom, Gyulakeszi, Hunya és Tófalu. A csoport közel 400000 fốt, Magyarország népességének 3,9\%-át tömöríti.

A 6. klasztert gyakorlatilag a legszegényebb, közszolgáltatásokkal nem vagy alig ellátott, 100 fốs vagy az alatti törpefalvak alkotják. Az idesorolt 100 településen összesen kevesebb mint 8000-en élnek, azonban közszolgáltatásokkal való ellátatlanságuk gyakran a települések rossz elérhetôségével párosul, így esélyegyenlôségi szempontból fejlesztésüktől nem lehet eltekinteni. A csoport Borsod-Abaúj-Zemplén, Baranya és Zala megyében túlreprezentált. A kultúra, mobilitás fốkomponens magas értéke itt az elvándorlással magyarázható (tekintettel arra, hogy a kapcsolódó két változó, az állandó és az ideiglenes vándorlási egyenleg elôjele a fókomponens értékekkel ellentétes irányú), ami az érintett falvak szempontjából nem feltétlenül pozitív jelenség. 100 fớ alatti településeken a vállalkozások 1000 fớre jutó száma és a többi, hasonlóan képzett mutató sajnos nagyon torzít, az 5. fớkomponens magas értéke nagy valószínúséggel ennek tudható be, nem pedig tényleges gazdasági fejlettségnek. Ebbe a klaszterbe tartoznak például Salföld, Varga és Gagyapáti települések.

A 4. táblázatot tekintve, szembetúnô, hogy ahol a közszolgáltatások jellemzése pozitív, ott általában a gazdaságé is az, és viszont. Ez alól kivételt - a statisztikailag következetlen gazdasági mutatókkal jellemzett törpefalvak csoportját leszámítva - csak részben a 4. klaszter jelent, ahol az alapfokú oktatással és körzeti egészségügyi szolgáltatásokkal való ellátottság jónak mondható, ellenben a gazdaság igen fejletlen. (Ez azért csak részben igaz, mert a többi közszolgáltatás már hiányosabban képviselteti magát.) Mindez alátámasztani látszik azt az elképzelést, hogy a közszolgáltatások (és ezen belül a felsôoktatás és kultúra), valamint a gazdaság jelenléte egymást erősíti.

A fentiekben három olyan településcsoport volt azonosítható, ahol a jólét alacsony szintú, illetve hangsúlyosabban jelen van a szegénység, és a gazdaság sem fejlett (4., 5. és 6. klaszter, össznépességszámuk több mint 2,7 millió fố, az ország népességének 27,5\%-a 2687 településen. Ezeken a településeken vagy a közlekedés, mobilitás (térbeli és társadalmi értelemben egyaránt) elôsegítésére, vagy a lakosságot és a vállalkozási szférát is megcélzó közszolgáltatás-fejlesztésre van szükség. ${ }^{6}$

\section{ZÁRó GONDOLATOK}

A társadalmi jólét területi eloszlása és a gazdasági egyenlôtlenségek a magyarországi politikai rendszerváltoztatás idején átrendezôdtek. Ezt az átrendezôdést jellemzóen az iparszerkezeti struktúra megváltozása, részbeni leépülése okoz- 


\section{Tudományos múhely}

ta, amely bizonyos területeken gazdasági és társadalmi fejlódést eredményezett, ugyanakkor más területeken pedig ellentétes hatást váltott ki. Habár ennek kiindulópontja a gazdaság, a manifesztuma pedig a lakónépesség jólléte, de amint az a keresztmetszeti vizsgálat eredményéből is látszik, a folyamatok hosszú sorának multiplikátorhatása - akár a demográfiai, társadalmi vagy gazdasági szegmens vonatkozásában - máig kihat, és ezt a hatást erôsíti a lakónépesség közszolgáltatásokkal való ellátottságának mértéke. A dokumentumelemzések során egyértelmúvé vált, hogy a közszolgáltatások integrált megszervezése gyakorta fiskális nyomás eredménye, viszont ezzel együtt, ha a támogatási feltételek módosulnak, az ellátásokban minôségi változás következhet be.

A javasolt irány meghatározásának alapja az a feltételezés, hogy a növekedés szempontjából nem közömbös tény, hogy tetten érhetố egyfajta sứrúsödô elhelyezkedés, ami által a pozitív (a termelési költséget csökkentô) és a negatív (a termelési költségeket növelô, például ingatlanárak, bérleti díjak) externáliák különbözô kombinációit hívják életre.

A továbbiakban érdemes lenne megvizsgálni azt is, hogy ugyanezen változókat kiindulási változókként használva milyen eredményt adna a fókomponens-, illetve faktor- és klaszteranalízis járási szintre aggregálva (lásd Lukovics-Kovács hasonló vizsgálata, 2008). Ez a vizsgálat bizonyos szempontból árnyaltabb képet adna, hiszen belépnének a vizsgálatba olyan, települési szinten „dummy” voltuk miatt ezzel a módszerrel nem kezelhetô vagy kis számosságuk miatt kiesố változók is, mint például az ipari parkok száma, a vasútállomások léte vagy nemléte. Ezen túl a legerôsebb változókat kiragadva érdemes lenne regressziós elemzést is lefolytatni mind a települési, mind pedig a járási adatsorokon, amelynek magyarázó változói a demográfiai és egyéb helyi adottságok, a helyi köz- és egyéb szolgáltatások lennének, eredményváltozója pedig valamely, a gazdasági fejlettséget jól reprezentáló indikátor (pl. hozzáadott érték vagy jövedelem). Számos tanulsággal szolgálhatna néhány nagyobb, összefüggó területi egység (pl. megye) gazdasági, földrajzi, történeti dimenzióval kiegészített, összefüggéseiben történô, monografikus jellegú vizsgálata a közszolgáltatások gazdaságra gyakorolt hatása szempontjából. Egy késóbbi, átfogóbb vizsgálat keretében pedig kísérletet teszünk a tér- és idôtávok, valamint az idôdimenzió beépítésére is.

\section{JEGYZETEK}

1 Fogyasztásából nem zárható ki senki, és egy fogyasztó felhasználása nem csökkenti a rendelkezésre álló jószág mennyiségét (például levegô, víz, természeti környezet stb.).

2 Fogyasztásukból a kizárás megtörténhet, holott az ilyen jellegú szolgáltatás nem rivalizáló piacon múködik. Például a televíziós csatornák szolgáltatásainak egy bizonyos része ilyen: egy fogyasztó semmit nem veszít az élvezeti értékből, ha mások is nézik a szolgáltató ugyanazon músorát, viszont ha ugyanez a fogyasztó nem fizet elô a csatornára, kizárják a szolgáltatásból. Jó példa lehet erre a fizetős közutak esete is.

3 Erre láthattunk szép példát abból az idôből, amikor a helyi közlekedés önkormányzati finanszírozási hatáskörbe került, és Magyarországon három városban (Esztergom, Jászberény, Salgótarján) tagadta meg a közszolgáltatás ellátását a területileg illetékes szolgáltató, és az érintett városokban a munkába és iskolába járást a személygépjármû́vek megosztásával oldotta meg a lakosság.

4 Ezeket az ismert és elfogadott elméletekkel meg tudjuk erôsíteni. 


\section{Tudományos múhely}

5 Hasonló módszertanú, de eltérô cél- és szempontrendszerú, részben eltérô változókat felölelố elemzésben hasonlóképpen járt el Magyarország falutípusainak meghatározása során Beluszky Pál és Sikos T. Tamás is átfogó 1982-es és 2007-es vizsgálata során, amelyekbốl sokat merítettek a jelen tanulmány szerzôii.

${ }^{6} \quad$ Itt jegyzendô meg, hogy amennyiben a jelen tanulmány beépítette volna a közlekedési távolságokat, illetve többféle megközelíthetôségi mutatót az egyes társadalmi rétegek különbözô közlekedési lehetôségeit is figyelembe véve, a Dunántúl (különösen Vas, Zala és Baranya megyék) településeinek egy része feltehetôleg kedvezóbb klaszterbesorolásba esett volna a közeli (al)központ(ok) szolgáltatásai miatt. Tanulmányunk azonban a (szúkebb érelemben vett) helyi, települési szempontokat vette górcsố alá.

\section{FelHaSZnÁlt IRODALOM}

Beluszky Pál - Sikos T. Tamás (2007): Változó falvaink. MTA, Társadalomkutató Központ, Budapest.

Beluszky Pál - Sikos T. Tamás (1982): Magyarország falutípusai. MTA FKI, Budapest.

Bodnár, Gábor (2013): Endogenous Development: Role of Territorial Capital in Rural Areas. In: Lengyel, Imre - Vas, Zsófia (eds.): Regional Growth, Competitiveness and Development. University of Szeged, Faculty of Economics and Business Administration, Doctoral School in Economics, Szeged.

Bourdieu, Pierre (1980): Le capital social. Actes de la Recherche en Sciences Sociales, Vol. 31, 2-3.

Camagni, Roberto - Capello, Roberta (2009): Territorial Capital and Regional Competitiveness: Theory and Evidence. Studies in Regional Science, Vol. 39, 19-39, https://doi.org/10.2457/ srs.39.19.

Camagni, Roberto - Capello, Roberta (2013): Regional Competitiveness and Territorial Capital: A Conceptual Approach and Empirical Evidence from the European Union. Regional Studies, Vol. 47, No. 9, 1383-1402, https:// doi.org/10.1080/00343404.2012.681640.

Capello, Roberta - Fratesi, Ugo (2012): Modelling Regional Growth: An Advanced MASST Mo- del. Spatial Economic Analysis, Vol. 7, No. 3, 293-318, https://doi.org/10.1080/17421772 .2012.694143.

Chapain, Caroline - Clifton, Nick - Comunian, Roberta (2013): Understanding Creative Regions: Bridging the Gap between Global Discourses and Regional and National Contexts. Regional Studies, Vol. 47, No. 2, 131-134, https://doi.org/10.1080/00343404.2013.74 6441.

Coleman, James S. (1988): Social Capital in the Creation of Human Capital. The American Journal of Sociology, Vol. 94, Supplement: Organizations and Institutions: Sociological and Economic Approaches to the Analysis of Social Structure.

Farkas Zoltán (2013): A társadalmi tốke fogalma és típusai. Szellem és Tudomány, 4. évf., 2. sz., 106-133.

Hoffman István (2006): Önkormányzati közszolgáltatások szervezése és igazgatása. ELTE Eötvös Kiadó, Budapest.

Jóna György (2013): A területi tôke fogalmi megközelítései. Tér és Társadalom, 27. évf., 1. sz., 3051., https://doi.org/10.17649/TET.27.1.2449.

Káposzta József (2014): Területi különbségek kialakulásának fốbb összefüggései. Gazdálkodás, 58. évf., 5. sz., 399-402.

Kiss Norbert (2011): A minőségi közszolgáltatások hozzájárulása a versenyképességhez. Nemzeti Foglalkoztatási Szolgálat, Budapest.

Kovács Árpád (2007): Töredékek a versenyképességrôl a fenntartható fejlődésrốl és a fenntartható jogállamról. In: Lentner Csaba (szerk.): Pénzügypolitikai stratégiák a XXI. század elején. Akadémiai Kiadó, Budapest, 225-244.

Kovács Eszter (2016): A belföldi vándorlás alakulása és hatótényezôi Európában. Elôadás, Haza szolgálatában konferencia, Nemzeti Közszolgálati Egyetem, Budapest.

KSH (2015): Megyei statisztikai évkönyvek. Központi Statisztikai Hivatal, Budapest.

KSH (2017): Éves településstatiszikai adatok a 2015ös településszerkezetben. Tájékoztatási adatbázis. Területi Statisztika, KSH, Budapest.

Lentner Csaba (2007): A magyar nemzetgazdaság versenyképességének új típusú tényezôi. In: Lentner Csaba (szerk.): Pénzügypolitikai stratégiák a XXI. század elején. Akadémiai Kiadó, Budapest, 271-296. 


\section{Tudományos múhely}

Lukovics Miklós - Kovács Péter (2008): Eljárás a területi versenyképesség mérésére. Területi Statisztika, 11. évf., 3. sz., 245-263.

Miklós-Molnár Marianna (2012): A helyi önkormányzatok addicionalitásának biztosítása. PhD-értekezés, Budapesti Corvinus Egyetem, Budapest.

Nemes Nagy József (2009): Terek, helyek, régiók. A regionális tudomány alapjai. Akadémiai Kiadó, Budapest.

Nordhaus, William D. - Samuelson, Paul Anthony (2012): Közgazdaságtan. Akadémiai Kiadó, Budapest.

Obádovics Csilla (2009): Klaszteranalizis. Eszterházy Károly Főiskola, Eger.

Obádovics, Csilla - Buder, Emese - Kulcsár, László (2013): Territorial Inequalities of Economic and Welfare Situations in Rural Hungary - Similarities and Differences. In: Bódi, Ferenc Fábián, Gergely - Lawson, Thomas R. (eds.): Local Organization of Social Services in Hungary. Crises - Reactions - Changes. Europaeischer Hochschulverlag, Bremen, 163-178.

Palotai Dániel - Virág Barnabás (2016): Versenyképesség és növekedés. Magyar Nemzeti Bank, Válasz Könyvkiadó, Budapest.
Pénzes János (2013): A foglalkoztatottság, az ingázás és a jövedelmi szint összefüggései Északkelet- és Északnyugat-Magyarországon. Területi Statisztika, 53. évf., 3. sz., 202-224.

Rechnitzer János (2002): A városhálózat az átmenetben, a kilencvenes évek változási irányai. Tér és Társadalom, 16. évf., 3. sz., 169-189.

Sajtos László - Mitev Ariel (2007): SPSS kutatási és adatelemzési kézikönyv. Alinea Kiadó, Budapest.

Siska Miklós - Szabó Tamás (2015): Preferenciák a közlekedési mód megválasztásában Magyarországon. Tér - Gazdaság - Ember, 3. évf., 3. sz., 81-100.

Székelyi Mária - Barna Ildikó (2002): Túlélókészlet az SPSS-hez. Typotex, Budapest.

Tipold Ferenc - Jusztin Valéria - Pikler Katalin Kelenné Török Lívia - Magyar Judit - Kohán Zoltán - Tafferner Bálint (2015): A Közép-magyarországi régió esetleges kettéválasztásának lehetôségérôl szóló vizsgálat. Nemzetgazdasági Minisztérium, Budapest.

Varga Attila (2006): Térszerkezet, technológiai fejlódés és makrogazdasági növekedés. Dialóg Campus, Pécs.

Wallerstein, Immanuel (1983): Labor In The World Social Structure. SAGE Publications, London. 


\section{A motiváció, a mozgásba hozás múvészete ${ }^{1}$}

\section{Informatikai technológiák alkalmazási lehetôségei a közigazgatási struktúrák fejlesztésében}

\section{Motivation, the Art of Setting Things in Motion}

\section{Application Opportunities of Information Technologies in Public Administration}

\section{ÖSSZEFOGLALÁS}

Tanulmányunkban többek között arra keressük a választ, mit tanulhat a magyar közigazgatás a tanulószervezetek eszmeiségéből, mennyire van jelen a mai magyar közigazgatásról, szervezéstudományokról való gondolkodásban, s legfôképp mely elemei játszhatnának kulcsszerepet a magyar közigazgatás megújításában, dinamizálásában, a közigazgatás „átlelkesítésében”. Emellett az informatika világából hozott innovációkkal, a blockchain-technológia lehetséges alkalmazási területeinek, lehe- tôségeinek bemutatásával kíván hozzájárulni Magyarország közigazgatási struktúráinak modernizációjához, fejlesztéséhez. A blockchain-technológia valóságos informatikai forradalmat indít el, amelyben az állam akkor maradhat versenyképes résztvevô, amennyiben élére áll az ilyen irányú fejlesztések alkalmazásának igazgatási struktúráiban.

Journal of Economic Literature (JEL) kódok: B22, E7, H11, H70, I30, M16, O33, Z13

\footnotetext{
Szarvas Hajnalka, PhD-hallgató, Nemzeti Közszolgálati Egyetem (hajnalkaszarvas@gmail.com), MAGYAR GÁBOR, programtervezô matematikus, egészségügyi szakközgazdász, Blockchain Expert Zrt. (gabor@blex.io), MEzô TAMÁs szoftvertervezô, Blockchain Expert Zrt. (tamas@blex.io).
} 
Kulcsszavak: motiváció, DLT/blokklánc, kriptopénzek, okosszerzôdés, hatékonyság, teljesítménynövekedés, tanulószervezetek

\section{Summary}

In this study we seek to know what Hungarian public administration can learn from learning organizations, to what extent this approach is present in its current practice and in organizational discourses in Hungary. According to the authors this approach can serve as a fundamental element in the modernization of Hungarian public administration. The paper also aims to contribute to the modernization of public administration by describing technological innovations, with focus on blockchain technology, which can accelerate procedures in the public sector. The use of blockchain technology has triggered a real IT revolution, and nation-states can only remain competitive if they adopt this technology for use in their services.

Journal of Economic Literature (JEL) kódok: B22, E7, H11, H70, I30, M16, O33, Z13

Keywords: motivation, DLT/blockchain, crypto money, smart contract, efficiency, performance improvement, learning organizations

\section{Bevezetés}

Tanulmányunk azt igyekszik feltárni, hogy a blockchain-technológia által kiváltható feladatok olyan hivatali teher alól szabadítják fel a közigazgatásban dolgozókat, amely alkalmat ad kreatív potenciáljuk, szakértelmük megfelelőbb szintú kibontakoztatásához, valóban létkiteljesítô mun- kavégzéshez, amely így rendkívüli mértékú hatékonyságnövekedést eredményezhet. Amint ez egyébként a nemrégiben közigazgatásban dolgozók között végzett empirikus kutatás adataira reflektálva, kívánatos is volna az ott dolgozók részéról. ${ }^{2}$

Amint ebből is látszik, tanulmányunk szemlélete annyiban kíván túlmutatni a témában megjelenô információs technológiai innovációt érintố írások megközelítésmódján, amennyiben e fejlesztések célját mélyebb, átfogóbb lételméleti kontextusba helyezve mutatjuk be a terület komplexitásának feltárásával. Amint Dávila kolumbiai író, filozófus fogalmaz: „Ha nem létezne transzcendencia, a Föld iparosítása lenne a történelem nevetséges kulminációja."” Mi tehát a pusztán technológiai alapú megközelítésen túllépve szeretnénk rávilágítani ezen alkalmazások tágabb lehetôségeire, összefüggéseire. A legújabb tudományos és technológiai újítások alkalmazása az állami múködés hatékonyabbá tétele érdekében megjelenik ugyanakkor Magyarország Alaptörvényében is kívánatos elérendô célkitûzésként. ${ }^{4}$ Emellett a Magyary Program keretében is kiemelten hangsúlyozott, átfogó feladatként jelenik meg a közigazgatás-fejlesztés terén, az egyre hatékonyabb feladat-végrehajtás érdekében, az informatika által kínált legalkalmasabb megoldások alkalmazása. ${ }^{5}$ Ennek természetesen nem csupán technológiai vetületeivel, hanem egyéb humán tényezóivel, kritériumaival is foglalkozni kívánunk.

Témánk egyik kiindulópontjaként a motiváció kérdésköre áll. Érdemes elôször a szó etimológiáját vizsgálni: a latin motivusból ered, jelentése: mozgató. Arra keressük tehát a választ, mi mozgatja az embereket legbelül, mi sarkallja nagyobb teljesítményre, melyek ennek 
legfőbb meghatározó tényezôi, s mindezt a közigazgatás megújításának kontextusában kívánjuk vizsgálni.

Ehhez elsốként hazai és külföldi mintákat vetünk össze, amely ugyan nem minden esetben szerencsés és realisztikus, mégis a részben egyesült államokbeli ihletettségú tanulószervezetek múködési elvei közül szemezgetünk. (Noha a tanulószervezetek Európában is ismert, a skandináv államokban is alkalmazott módszer, többek között a demokratikus nevelés témakörében is, s alapelveit tekintve a Karácsony Sándor által megfogalmazott pedagógiai elvekben is megjelenítôdik esszenciájuk.)

Boldogságkutatás a közigazgatásban: utópia?

Vajon mi áll az amerikai sikertörténetek hátterében? Nem az amerikai álomra gondolunk, ami tulajdonképpen eredeti jelentésében nem is biztos, hogy létezô vagy a ma embere számára igazán legvonzóbb víziót jelöli. Célunk inkább az, hogy a közigazgatásról és annak lehetséges átalakítási irányairól merjünk egy meróben eltéró módon gondolkodni. Túlzásnak túnhet, mégis Csíkszentmihályi (2009) kérdése világít rá talán a leglényegesebb kiindulópontbeli különbségre, amely a jövő́ben követendô újszerú gondolkodásmód alapját is képezheti: „Boldogabbá teheti-e az emberek életét?" (Csíkszentmihályi, 2009:26).

Bár vakmerốnek túnố gondolat a közigazgatás szervezeti kérdéseit a boldogságkutatások szemszögébôl átgondolni, mégis a kis, kétezer lelket számláló Pázmánd önkormányzatának példája mutatja, hogy múködôképes, itthon is hatékony megközelítésról van szó. Itt ugyan a polgármester asszony inkább a keleti Bhután példájából indult ki, mégis a vezérló elv az önkormányzati munkamorál átszervezése során hason- lóan a fenti kérdésre adandó lehetséges válaszokból indult ki, s 2010 óta szép sikereket ért el. Csíkszentmihályi a következó példával igyekszik megragadni a modellben rejló motivációs erôt, ami a megújulás, innováció és inspirációk forrása lehet egy sikeres üzleti vállalkozás esetében: „Fiatal emberek özönlenek az olyan vonzó helyszínekre, mint pl. Szilícium-völgy és Salt Lake City, vagy olyan kampuszokra, mint például a Microsoft redmondi központja. Azonban a luxus, a túlságosan hivalkodó környezet nem szükséges, sốt még káros is lehet. Az egyik legboldogabb cégközpont, ahol valaha jártam, a Patagonia szabadidô- és sporteszközgyártó volt, amely egy nemrégiben felújított, 1930-as évekbeli gyárépületben kapott helyet, az álmos kaliforniai Ventura szomszédságában. A bejárati előtér két oldalán szörfdeszkák sorakoztak, amelyeket a dolgozók támasztottak a falaknak, Yvon Chouinard így magyarázta a dolgot: Üzletember vagyok, de a magam módján. Le akarok rombolni egy csomó korlátot, szeretnénk elmosni a határt a munka és a játék között. Ezért kialakítottunk egy olyan rendszert, amit így hívunk: »Hadd menjenek az emberek szörfözni.« Ez egy olyan rendszer, hogy ha hullámtörés jön, bárki elmehet szörfözni. Bármikor a nap folyamán, csak fogod magad, és elmész szörfözni. Ez a szemléletmód megváltoztatja az egész életedet. Ha úgy van az életed berendezve, hogy bármi kieshet a kezedból, ha hullámtörés jön, másképp fogod élni az egész életed. És ettôl persze minden más lett itt, a vállalatnál is." (Csíkszentmihályi, 2009:26)

Rendkívül merész összehasonlítás, és természetesen elsố hallásra talán nem is túnik realisztikusnak egy ilyen szemlélet bárminemú adaptációja a hazai közigazgatási viszonyokra. Több szempontból is 
nehézségekbe ütközhet a példa átültetése, nyilván önmagában az üzleti szféra törvényszerúségei eltérôek a közigazgatás világához képest, s egy egyesült államokbeli innovatív vállalkozás merôben más kulturális társadalmi kontextusa is nehézkessé teheti a példa befogadását. Ugyanakkor ha elvonatkoztatunk a konkrétumoktól, s megpróbáljuk kivonni az e mögött rejló esszenciát, nem kizárt, hogy kétségtelenül új és szokatlan, mégis potenciálisan múködóképes utat fedezhetünk fel.

\section{Jövóképzés a jelenre hangoltan}

Ehhez persze egy egészen más megközelítés szükséges, amit Otto Scharmer, az U-elmélet megalkotója valahogy úgy foglal össze, mint „képes lenni egy olyan közös jövốképzésre, ahol a tartalmak már nem a múlt emlékeinek átrendezôdésébốl, hanem az eddig még soha nem manifesztálódott, de a teremtó jelen örökös terében potenciálisan ott rejlô lehetôségekből bontakoznak ki" (Ruzsa-JobbágySzentirmai, 2012; Scharmer, 2013).

Tehát egy ilyen jövớre nyitott, jelenben születni akaró erôvonalakra hangolt szemléletmód képes lehet az olyannyira új megközelítések befogadására is, mint a fent vázoltak. Frederic Laloux (2016) munkájában szintén kifejti, mennyire meghatározó a szervezetek esetében a felsố vezetốk szemléletmódja, előfeltételezési rendszere a tényleges múködésre (Laloux, 2016:159). Elgondolkodtató lehet, hogy az általa említett 1980-as években egy hagyományos gyár felsố vezetése miként vélekedett az ott dolgozókról, s ez mennyiben határozta meg a tényleges múködést. A jellemzők között felsorolják a lustaságot, feltételezték továbbá, hogy nem megbízhatóak, s nem intelligensek. Remélhetôleg ha ugyanezt a kutatást a magyar közigazgatásban dolgozó felsố vezetôkkel készítenénk ma, nem kapnánk hasonló eredményt. Laloux folytatja: Jean-François Zobrist, a korábbi ejtóernyôs, a FAVI vezetôje kollégáival együtt a fenti feltételezések helyett 3 új előfeltételezést, vagy ha úgy tetszik, hiedelemrendszert alapozott meg, kicserélve a korábbiakat a következókre:

- Az emberek következetesen jónak tekintendốk (megbízhatóak, önmotiváltak, becsületesek, intelligensek).

- Nincs teljesítmény boldogság nélkül. (Hogy boldogok lehessünk, motiváltnak kell lennünk. Ehhez azonban felelósséget kell éreznünk. Felelôsek pedig akkor lehetünk, ha tudjuk, miért és kinek dolgozunk, és szabadon dönthetünk a hogyanról. $)^{6}$

Vajon hogy lehet olyan szervezeti múködést, légkört kialakítani, amelyben az ott dolgozók valóban a legteljesebb mértékben ki tudnak bontakozni, képesek a képességeiket felszínre hozni, növelve így a szervezeti intelligenciát, s tulajdonképpen boldogok?

\section{A tanulószervezetek LEgFontosabB JELLEMZŐI}

E tanulmány keretein belül tehát a tanulószervezetek megközelítésébốl kiinduló néhány szempontot szeretnénk bemutatni, amelyek ezen szervezetek alapvetô légkörét, múködésmódját meghatározzák, hozzájárulva így a fenti célokhoz, a szervezetben tevékenykedôk fizikai-lelki-szellemi jóllétéhez, boldogságához.

\section{A szervezeten belüli figyelem minösége:}

Peter Senge számos beszédében hangsúlyozza a szervezeten belüli figyelem minôségével kapcsolatban, hogy itt nem a mindennapi életben, szóhasználatban 
alkalmazott hétköznapi figyelmi szintrôl van szó, hanem egy jóval mélyebb figyelemrôl, amely igazán segíti a szervezetben jelen lévôk kinyílását és legmélyebb, rejtettebb potenciáljuk feltárulását. Fontos minốségi jellemzôje ennek a mélyebb figyelmi szintnek, hogy igazán befogadó, az ítéletalkotás, bárminemú véleményezés nélkül a meghallgatás során.

A szervezeten belül a közös tevékenységbe bekapcsolódás, részvétel lehetösége, illetve a szervezeten belüli elfogadás, megbecsülés szintje: $\mathrm{Az}$ MIT kollektív intelligenciát vizsgáló kutatócsoportja emellett két további fontos tényezôt talált, amely alapvetôen határozza meg a szervezeti intelligencia szintjét. Ezek a csoport munkájában való aktív részvétel, bevonódás lehetôsége, és az elfogadás, megbecsülés szintje a csoporton belül, amely a megnyílás érzelmi alapját képezi, érzelmi biztonságot teremt. ${ }^{7}$

Az elsóként említett figyelmes jelenléttel kapcsolatban egyre szélesebb körú kutatások folynak a nemzetközi kutatási életben, s hazánkban is kezdenek megjelenni az ezt vizsgáló tudományos eredmények. Csakúgy, mint a nemrégiben a Budapesti Corvinus Egyetemen Contemplative Science and Management címmel rendezett konferencián, ${ }^{8}$ ahol a világ legnevesebb egyetemeiról érkezett kutatók adtak eló (többek között Claire Brown a University of California at Berkeley-ról, vagy Illés Katalin a londoni Westminster University Business Schoolból, de érkeztek a Torinói Egyetemról is, vagy éppen Bergenből, a Norwegian School of Economicsról s számos egyéb egyetemról). Ahol is ugyanezt az éber, figyelmes jelenléten alapuló vezetést és tudásmenedzsment-folyamatokkal kapcsolatos kutatási eredményeket tárták egymás elé.
A Párbeszéd Házában Mindfulness címmel rendeztek konferenciát 2017-ben. A mindfulness MbSR Jon Kabat-Zinn, a University of Massachusetts Medical School prosfesszora, a Cambridge-i Zen Központ alapítója nevéhez köthetô. Távol-Keleten töltött évei során megismerte a különbözố keleti hagyományok relaxációs, meditációs technikáit, s mindezt ötvözve a nyugati tudományos eredményekkel, megalkotta a módszert, amelyet ma már a világ több ezer kórházában nagy hatékonysággal alkalmaznak a krónikus, illetve halálos betegek kezelése során. Azonban nem csupán egészségügyi intézmények alkalmazzák a metódust, hanem a menedzsmentirodalomban és szervezetkutatásokban is világszerte egyre inkább kutatott, alkalmazott módszer. A kognitív pszichológia, illetve az agykutatás eredményei egyaránt a megközelítés rendkívüli hatékonyságáról tesznek tanúbizonyságot. A konferencián Rajkai Csaba pszichiáter az agykutatás eredményei alapján bemutatta a tudatosfigyelem-alapú jelenlét kognitív teljesítményre, illetve testi-lelki egészségre gyakorolt pozitív hatását. ${ }^{9}$

Integritásminta, éló, organikus szervezetkép

A tanulószervezetekrốl való gondolkodást alapvetôen határozza meg az a fajta organikus szemlélet, ami a szervezeteket éló egészként elképzelt jelenségeknek látja, amelynek van egyfajta belsô önszervezódése, önmenedzselése, egy olyan kollektív szervezeti tudat, ami önmagát szervezi meg. Ennek magyarázatára Senge et al. (2004) Buckminster Fuller feltalálóhoz fúzôdô történetet hoz fel, amely tulajdonképpen az integritás lényegét mondja el, miszerint valójában semmi sem te- 
kinthetô állandónak, minden folyamatos változásban van, csak látszólag túnhet statikusnak, s valójában egy mögöttes szervezômintázat az csupán, amely tartalmazza az egész képét. Nem másról van tehát szó a szervezetek szintjén sem: mint minden a természetben, ezek is folyamatosan változnak, átalakulnak, növekednek részeikkel együtt. Gábor Dénes hologramfogalma már elôrevetítette a holografikus univerzumról szóló szemlélet lényegét, mely elméleti keretét adja ennek a felfogásnak. Ahogy Gauthier (2011) fogalmaz az integrálszemléletú vezetés kapcsán: „Meghatározó fejlődésparadigmánk alapvetôen maszkulin, patriarchális értékeken nyugszik, négy önmagát megerôsító építôkövön, jelesül: Az emberi természet materialisztikus, a libidó által vezérelt, agresszív és a természettól elkülönült, szétválasztott. Ez a fejlődési paradigma legalább 100 évre tekint vissza, Freud és mások által terjedt el” (Gauthier, 2011).

\section{Önmenedzseló szervezetek}

Ehhez hasonló elképzelést látunk a TEAL-szervezetek esetében is, Laloux (2016) pontosan ugyanezen új paradigma alapján fogalmazza meg az önmenedzseló szervezetek építôköveit, amelynek egyik sarkalatos pontja tehát teret adni annak a fajta önszervezódési folyamatnak, amely a természetben is fellelhetô, és a szervezetben is kibontakozhat megfelelô körülmények hatására. A fent említett Zobrist és más vezetốk ezt felismerve tulajdonképpen nagyon gyakran csupán teret adtak ennek az önmenedzseló, magától múködô folyamatnak, s így kényes kérdéseket, akár leépítésekkel kapcsolatos vezetői döntéseket sikerült a szervezetnek magának, vezetôi döntés nélkül megoldani.
Tér-teremtés az önszervezôdô múködéshez, mint alapvetó kiindulópont

Az MIT-n alakult Society for Organizational hazai szervezetének vezetôje is hasonlóképp ültette át magyarra a tanulószervezetekben alkalmazott módszertan lényegét. A nemzetközi, Art of Hosting $(\mathrm{AOH})$ módszertan magyarul ugyanis Tér-teremtésként terjedt el a Sol-os szóhasználatban, utalva arra, hogy ezen folyamatoknak valójában egyik leglényegesebb katalizátora pusztán az, hogy teret adunk, hogy maguktól megtörténjenek, az önszervezôdésnek. ${ }^{10}$

\section{Dialógus a tanulószervezetekben}

A tanulószervezetek módszertana, a tudásmegosztás, a szervezeti tudás felszínre hozásának bevált módja a David Bohm elméleti fizikus által megalkotott dialógus. A dialógus kapcsán maga Bohm a szó elemzésével kezdi, és kifejti, hogy a szervezeti megbeszéléseken gyakran tapasztalhatók a discussio latin eredeti értelmét tükrözi („összetörni, széttörni, legyôzni”). Ez azonban nem segít új tudások előhozásában, sốt inkább gátja annak. A dialógusfolyamatban ellenben valódi, mélyebb szintú értelemkeresés zajlik, ahol nem a másik legyôzése a cél, hanem olyan közös jelentésáram megragadása, ami az eredeti értelmezésen keresztül elvezet valami többhöz, ami túlmutat önmagán. Ilyenformán ha egy megfelelố participációs tér kialakításával teret engedünk egy ilyen dialógusnak, akkor azon jelen lévố lehetôségek is felbukkanhatnak, amelyekre a korábbi tárgyalási stílus, szervezeti megbeszélések színvonalán nem lett volna mód. A dialógusfolyamatban továbbá sor kerül a mélyen 
meglévố axiómáink, „megkövesült meggyőződéseink" feltérképezésére, amelyrôl Otto Scharmer az U-elmélet néven tesz említést, Peter Senge pedig reflexív huroknak is nevez. A tudatunkban mélyen ülô előfeltételezések valóságalakító erejével már Wittgenstein is foglalkozott $A z$ európai kultúrkör fundamentális vélekedései címen. Tulajdonképpen az amerikai menedzsmentirodalomban most ezen meglátások élik reneszánszukat. Nem annyira új megközelítésmódokról van tehát szó, legfeljebb újra felfedezettekrôl, vagy eddig kevésbé széles körben elterjedtekrôl.

Amint Bohm magyarázza, a dialógus során a tagok között és által létrehozott jelentésáramból új megértés születik, olyasmi, ami nem volt jelen kezdetben. Számos, akár nemzetközi szervezetben, így az ENSZ-ben is gyakorta megfigyelhetô, hogy nem a lényegi kérdésekrôl vitáznak, hanem sekélyes vitákba bocsátkoznak, s közben a leglényegesebb tabutémák kerülgetése elveszi az igazán múködô megoldások fellelésének lehetôségét. A Process Oriented Psychology (POP) irányzatának is egyik fó feltevése, hogy az adott csoportban jelen lévô „ghost”ot, azaz egyfajta, mindenki által tudott, érzékelt, mégis tabutémaként kezelt kérdéseket kell elôször beazonosítani, néven nevezni a folyamat elôrehaladásához. A nagyon mélyen identitáshoz kapcsolódó kérdésekben valószínúleg teljesen más módszerrel lehet eredményt elérni, mint azokban a kevésbé a személyiség magját érintô kérdésekben, ahol akár egy Fisher-Ury (1981) által megfogalmazott tárgyalástechnika is segíthet.

A dialógus folyamata tehát elsốként igyekszik valamiként a csoportban mélyebb szinten jelen lévô feltételezéseket is detektálni, hiszen igazán így tudnak ezek megnevezésével nyitottabb gondolati teret létrehozni új meglátások felszínre jövetele számára. Bohm a következốképp fogalmazza meg a dialógus lényegét: „A kollektív gondolateró sokkal erôteljesebb, mint az egyéni. Sôt, az egyéni gondolat az esetek többségében a kollektív gondolatból fakad, de legalábbis interakciókban születik meg. A nyelv teljes egészében közösségi, és az általa megfogalmazott gondolatok nagy része is az. Mindenki hozzátesz valamit a közösség gondolatáramához. De nagyon kevés ember képes azt megváltoztatni. A csoport ereje sokkal gyorsabb hatású, mint a résztvevớké egyenként és külön-külön. Olyan, mint a lézersugár. A hagyományos fényt inkoherensnek tekintjük, ami azt jelenti, hogy minden irányba szétszóródik, és a fényhullámok nem azonos fázisúak, így nem adódnak össze. A lézerfény azonban nagyon erôs, intenzív fénysugár, ami koherens. A fényhullámok összeadódnak, mivel mindanynyian ugyanabba az irányba tartanak. Ezzel a fénynyalábbal minden olyan dolog elvégezhetô, amire a szórt fény esetében még csak gondolni sem lehet. Igen, bátran állíthatjuk, hogy a szokásos, hétköznapi gondolkozás nagyon szétszórt, minden irányba hat, egymásba ütközik, és egymást kioltja. Ha azonban az emberek képesek lennének a koherens együttgondolkozásra, akkor annak felmérhetetlen hatása lenne. A dialógussal erre hívom Önöket" (Bohm, 2011:23).

A dialógust továbbá jellemzi, hogy általában nincs elôre kialakított napirend s kijelölt vezetố, így tehát vállalati környezetben újszerúen hathat a bevezetése, azonban egyre több ilyen innovatív szellemben vezetett vállalattal találkozhatunk, és intuitív vezetôkkel, mind az 
Egyesült Államokban, mind hazánkban. ${ }^{11}$ A körben történô elhelyezkedés is fontos eleme ezen folyamatoknak, ugyanis ez teret ad a közvetlen kommunikációra minden részt vevô fél számára.

Bohm egy antropológus észak-amerikai törzsnél tett látogatásának tapasztalatait is felhozza, amikor a dialógus hatásairól kíván szólni. A törzs tagjai rendszeresen összeültek beszélgetni, ahol mindenki szót kaphatott, s ezen gyakori beszélgetések lehetôvé tették, hogy megismerjék egymást, egymás álláspontját, s gyakorlatilag egyfajta csoportos gózkieresztô szerepe is lehet az ilyen csoportos beszélgetéseknek, amelyeket eleinte facilitátor vezethet, aki fokozatosan feleslegessé teszi a szerepét a csoportban. Bohm igazi dialógusnak azt nevezi, amikor minden résztvevő előfeltevéseit sikerült felfüggeszteni, s így valóban üres, szabad teret teremteni a közös jelentésáram kibontakozásához, így mindenki az egész csoport jelentésmezőjének résztvevője lesz, részvételi, participatív tudatosság alakul ki a csoportban. Ez a közös megértés, közös jelentés hív aztán közös cselekvésre. Bohm értelmezésében a részvétel tehát részvállalást szül a folyamat során. Ugyanakkor fontos hangsúlyozni, hogy itt nem a tömegtudat irányába mozdul el a folyamat, nem cél, hogy a kollektív elme vegye át az uralmat, hiszen ebben a folyamatban helye van az egyéninek is. Inkább a kollektív és az individuális, az egyéni és közösségi közötti koherenciára törekszik, mint magyarázza a szerzô. Amint kifejti, a társadalom közös jelentésmezôn nyugszik, s ez adja a kultúra alapját, s ezt vagy ezeket a rétegeket kell felszínre hozni a dialógusfolyamat során. Manapság ugyanis a legtöbb esetben inkább inkoherens jelentésmezôvel találkozunk.
Bencsik (2005) szerint ma azon szervezetek lehetnek sikeresek a tudás megszerzésében, amelyek stratégiájukban hangsúlyt helyeznek tudásmenedzsment-rendszereik múködtetésére, és ezek alapvetô feltétele a tanulószervezetként való múködés. A tanulószervezetként múködés fố célja álláspontja szerint a szervezeten belül meglévô rejtett tudások előhozása, mozgósítása. Ebben lehet tehát a fent részletezett bohmi dialógus a szervezetek nagy hasznára (Bencsik, 2009:13-202). Senge (1998) a tanulószervezetek öt alapelvét a következóképp fogalmazza meg: rendszerben való gondolkodás; önfejlesztés, önirányítás; közös jövôkép; belsố meggyốzôdés (attitưdváltozás, gondolati minták); csoportos tanulás, team-munka (Senge, 1998).

\section{Field of Future}

Lényeges eleme a tanulószervezeteknek a fent már említett jövô felé irányultság, a jelenre hangolódva. Hogy mit is jelent ez pontosan? Tulajdonképpen egy olyan szemlélet megvalósulását, amely igyekszik ráhangolódni arra, ami születôben van, a jelenben rejló feltáratlan potenciálokra, rejtett tudásokra, amelybôl új lehetôségek születhetnek.

Ez lehet tulajdonképpen a tanulószervezetként múködô szervezetek innovatív kapacitásának fố kulcsa, forrása. Tulajdonképpen Senge és szerzôtársai (2004) Presence címú munkájukban a tanulás egy új felfogását vetik fel. Nézetük szerint nagyon gyakran cselekedeteink reaktívak, félelem és szorongás által vezéreltek, túlélésre irányulók, s nincs ez másként szervezeti szinten sem. Ilyenkor olyan szokásszerú automatizmusok, sémák lépnek életbe, amelyeket az a feltevés vezet, hogy 
tulajdonképpen nincs ráhatásunk a dolgok menetének megváltoztatására. Ugyan David Bohm nézete szerint is limitált a szabadságunk e téren, mégis a szerzôk azt próbálják felvetni, hogy az ismerôs sémákon alapuló reaktív tanulás helyett valami más múködésmód viheti elôre a szervezetek világát, múködését. David Bohm is szót ejt az énvédố mechanizmusok korlátozó szerepéról, s nagyon gyakran ezek a védekezési mechanizmusok a mérvadóak a szervezeti megbeszéléseken, $\mathrm{s}$ ez a szervezeti tanulás folyamatát is limitálja. Egy mélyebb figyelmi szint a jelenre segíthet, hogy cselekvésünk ne múltbeli szokások ismétlése legyen csupán, azaz reaktív, hanem igazi teremtố, innovatív akció, amely drámai mértékben hozzájárulhat szervezeteink hatékonyságának növeléséhez. Ehhez az a fajta Létegészhez viszonyulás szükséges, amelyet Heidegger is felvet múveiben. Fel kell tehát tárnunk az aktuális helyzet gyökerét, és összefüggéseit a nagyobb rendszerekkel, és azt, hogy ezekhez a rendszerszintú valóságokhoz milyen módon kapcsolódunk. Ekkor helyzetünk pontosabb ismeretében megfelelôbb ítéletet hozhatunk a kívánatos akció jellegérốl.

$\mathrm{Az}$ eddigieket összefoglalva elmondhatjuk tehát, hogy a legfontosabb minôség a tanulószervezetekben az a fajta tudatosabb, elmélyültebb, koncentráltabb figyelemmel való jelenlét, amely a figyelem egy mélyebb szintje által képes meglátni és megragadni a jelenben lévô kiaknázatlan lehetôségeket, s így soha nem látott innováció és versenyelôny forrását képezze a szervezetek számára. Ez a fajta jelenlét a régi identitások levetkózését is jelenti szervezeti szinten, hogy ez utat tudjon engedni a formálódó jövônek, s így már nem a múlt szcenárióit fogjuk újratermelni, hanem a múlt terheitôl men- tes vízió megvalósítására leszünk képesek. Érdemes ugyanakkor kiemelni Valeyre és társai kutatásának eredményeit, melynek végkövetkeztetése szerint: „...a tanulási kapacitással és a munkavállalók magas szintû́ problémamegoldó tevékenységével jellemezhetố új munkaszervezeti formák nem köthetốk egyetlen modellhez, hanem egyaránt jellemeznek két különbözó modellt: a többé-kevésbé decentralizált és nagy munkavállalói autonómiával jellemzett, diszkrecionális tanulási modellt (tanulószervezetek), illetve a hierarchikusabb, korlátozott munkavállalói autonómiával jellemezhetố, ún. karcsúsított munkaszervezeteket, melyek egyaránt jelen vannak az Európai Unió gazdaságában" (Valeyre et al., 2009). Szintén érdekes megállapítás témánk szempontjából az „új” tagállamokra vonatkozó tanulószervezetek arányával kapcsolatos információ: „Az újonnan csatlakozott országokra - hasonlóan az EU-15 északnyugati (vagy angolszász) és déli országaihoz - is igaz: kevésbé elterjedtek a diszkrecionális tanuló munkaszervezetek. Az egyetlen kivétel ebbốl a szempontból Málta, a tanulószervezetek átlagnál valamivel nagyobb mértékú gyakoriságával, valamint Észtország és Magyarország, átlag körüli elôfordulással" (Valeyre et al., 2009).

\section{INNOVATÍV, HATÉKONYSÁGNÖVELÓ TECHNOLÓGIÁK A KÖZIGAZGATÁSI STRUKTÚRA FEJLESZTÉSÉBEN ${ }^{12}$}

Rendkívül divatossá vált napjainkban a már félig kiforrottnak tekinthetô DLT/ blokklánc (distributed ledger technology, elosztottfốkönyv-technológia), amit közkeletû nevén blockchainnek neveznek. Az elnevezés még nem véglegesült, ezért mi DLT/blokklánc alakban használjuk. 
A legismertebb Bitcoin és Ethereum kriptopénzrendszereket e tároló és hitelesító technológián múködtetik. Röviden összefoglaljuk, miért alkalmas a közigazgatás jövóbeli infrastruktúráját is erre alapozni.

A hírekbool (és sokunk saját tapasztalatából is) tudható, hogy DLT/blokklánc csomópontok üzemeltetése kifizetôdô (Memani, 2017). Ezért sok millió, egymástól független ember és vállalkozás szervezôdik „bányatársaságokba”, és múködtetnek DLT/blokklánc csomópontokat szerte a bolygónkon. A DLT egyedülálló tulajdonsága - mégpedig a mai, központiadatbázis-technológiákkal szemben -, hogy nem lehet kikapcsolni, megsemmisíteni, megváltoztatni. Minden adat minden idôponthoz tartozó értéke örökre megórződik. Ezt az biztosítja, hogy sok független DLT/ blokklánc csomópont-üzemeltetố van a Földön, és minden csomópont ugyanazt az elosztott fốkönyvet kezeli. Még egy globális háború után is maradnának meg (esetleg áram híján álló) csomópontok, ezért a teljes adatvesztés szinte kizárt.

Mielôtt kifejtenénk a hazai alkalmazási lehetôségeket, érdemes megemlíteni, hogy a blockchain-technológiát Észtország már nagy sikerrel alkalmazza többek között az egészségügyi nyilvántartások terén. „A közigazgatást már teljesen digitalizálták, a polgárok online szavaznak, az egészségügyi adatokat blockchainalapú megoldással tárolják, sốt az ezredforduló óta már a kormányüléseket is sikerült teljesen papírmentessé tenni" - mondta Taavi Kotka, az ország fóinformatikusa. ${ }^{13}$

\section{Közösség és blockchain}

A DLT/blokklánc múködése és a tradicionális emberi együttélési formák múködése között számos hasonlóságot találunk (hitelesség és a múködtetés biztosítása). A hagyományos közösségek (pl. régi magyar falu) életében a legfontosabb szakrális események (kereszteló, esküvô, temetés) idején az egész falu összejött, hogy tanúja legyen, emlékezzen, és lássa, hogy a szertartás valóban megtörtént, mégpedig a helyes módon, hogy mindenki a saját szemével látta (Szarvas-Mezó, 2017).

A pénzrendszer abban hasonlít a szakralitásra, hogy a pénz értékét kizárólag a belé vetett hit és az ehhez kapcsolódó érdekek tartják fenn. Régebben aranytartalommal, késóbb aranyfedezettel tartották fenn a pénz hitelességképét. A mai pénzrendszerek hitelességét szigorú elszámolási szabályozással és hamisítás elleni védelemmel biztosítják. Kontraproduktív, hogy banki titok lengi körül a pénzek világát, így néhány hatóság adott szavára vagyunk utalva, ha meg akarunk gyôzôdni a valós pénzkezelési gyakorlatról. A titkolózás a szavahihetôség komoly gátja. Ez az, amiben a DLT/blokklánc technológia áttörést hozott, nyilvánosan könyvel, nyilvános szabályok szerint, így bárki meggyốzôdhet az elszámolási gyakorlat helyességéról. A nyílt lapok teszik hitelessé a rendszert, ahogy fentebb, a falu esetén is láttuk.

A DLT/blokklánc egyik lényegi eleme, hogy az egyenrangú informatikai csomópontok mindegyike önmúködôen, azonos szabályok alapján könyveli a rendszerben indított tranzakciókat. A tranzakciókat kötegekbe gyújtik, és néhány másodpercenként pénzügyi zárást végeznek e kötegeken (block). Ezután a csomóponti gépeknek egy óriási számítási teljesítményt igénylô kriptográfiai feladatot is el kell végezniük, ami ráadásul véletlenszerúen hol egyik, hol másik csomópontot hozza ki győztesnek. A gyôztes 


\section{Tudományos múhely}

kihirdeti az eredményét, az összes többi pedig ellenôrzi. Ha a többi szerint hibázik a gyốztes, akkor újraindul a versengó feladatmegoldás a gyôzelemért. Nem juthat át szabálytalan vagy hibás eredmény a rendszeren. Az így elfogadott tranzakciókötegre pecsét kerül azáltal, hogy ellenôrzố kódja bekerül a következố köteg metaadatai közé, majd az is lezáratik és így tovább. (Ezt a folyamatot DLT/blokklánc konszenzusnak nevezik, a kötegek láncolatát pedig blokkláncnak, angolul blockchainnek.) Mivel pedig folyamatos üzemben megy a feladatmegoldás és a lánc továbbfúzése, ha valaki a következô körben hamis megoldást akarna a rendszerbe bevinni, azt csak úgy tudná, ha az összes többi csomópont együttes teljesítményénél is nagyobbat adna bele. Ez pedig nem kifizetôdô. Kevesebbet tudna csalni, mint amennyibe ez kerül. ${ }^{14}$

A DLT/blokklánc alapú hálózat skálázhatósága rendkívüli, ezért világszámítógép-architektúraként is szoktak róla beszélni. És valóban, több millió csomópont teljesítménye felülmúl mindent, ami eddig létezett. Olyan nagy ez a rendszer, hogy készakarva végeztetnek vele nehéz kriptográfiai munkát, hogy lassítsák. Ez nemcsak a hamisítás ellen véd, de segít szinkronban tartani a rendszert..$^{15}$ Természetesen a skálázhatóság nem határtalan, de újabb módszerektôl komoly áttöréseket vár a szakma.

$\mathrm{Az}$ emberi együttélés múködésére még két dologban hasonlít. Az egyik a jutalmazás: amelyik csomópont megold egy feladatot, azé lesz a tranzakciós díj és - ha van - szabályban elôírt mennyiségú pénz teremtésének joga is. A munkát meg kell fizetni, ez ösztönöz munkára. Egy pénzrendszernél ez természetes, de ha jobban meggondoljuk, minden emberi munka- megosztásnak is ez az alapja. A jutalmazás pedig érdekeket szül. A rendszert úgy alakították ki, hogy a rendszer hitelessége és múködése legyen minden csomópont elsôdleges érdeke. Ez is évezredes tanulsága az emberi együttélésnek. Csak olyan közösségek, társadalmak, vállalkozások és társaságok maradtak fenn, amelyek felismerték az együtt maradás szükségességét, és szabályaikat úgy alkották meg, hogy az így kialakított érdekek ezt a rendet erôsítsék. Eleink tisztában voltak a piaci logikával és az emberi szükségletekkel, és e tudásukat jól alkalmazták a szabályalkotásban.

A DLT/blokklánc hitelességét az alapozza meg, hogy mindenkinél ugyanaz a nyilvános fớkönyv van. Nincsenek üzleti titkok, államtitkok, minden nyilvános. Éppen csak anonim. Ugyanis a felhasználók maguknak névtelen számlákat nyitnak, amik csupán véletlen számokként látszanak a nyilvános fốkönyvben. Ott jól látszanak a tranzakciók és azok teljes elốzménytörténete a pénz eredetéig, de nincs egyetlen név sem. Ez nagyon fontos tulajdonság pl. egészségügyi vagy adózással kapcsolatos közigazgatási rendszerek múködtetéséhez. Még tajszám sincs, csak külön-külön tranzakciók (pl. orvoslátogatások, kivizsgálások, diagnózisok, beavatkozások, receptek). Csak az tudja a saját kórelózményét, akire tartozik, akinél a tranzakciókhoz tartozó titkos kulcsok vannak. Ố átadhatja az orvosának, rendelkezhet minden adatáról. Akár meg is semmisítheti.

Önmúködố szerzôdés

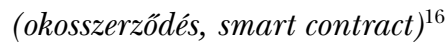

A DLT-re egy önmúködô szerződésréteg is ráépült (itt az Ethereum-rendszert ismertetjük). Az önmúködó szerzôdés egy 
szabályalapú programnyelven írt program. Sok, egyszerú esetekre kész sémákat találunk ilyenbôl. Ha interneten vásárolunk, akkor kiválaszthatjuk például, hogy az áru postán átvételekor történjen a fizetés. Amikor a posta igazolja az átvételt, akkor a szerződés programja ráfut a fizetés ágra, és magától megtörténik a tranzakció. Mire hazaérünk a postáról, az eladó már megkapta a pénzét.

A szerzôdések hierarchiába szervezésével teljes jogrend vagy igazgatási eljárásrend programozható le. Tranzakció lehet pénzügyi átutalás, de üzenet küldése vagy fogadása is, bármilyen esemény rögzítése is. A rendszert éppen igazgatási, végrehajtási szint múködtetésére találták ki. Minden nyilvános, de névtelen, minden hiteles, minden esemény idôrendben rögzített, és lehetetlen törölni vagy hamisítani egyetlen adatot is. Nincs többé összeragadt papír, beteg ügyintézô. Igazából ügyintézô sincs, mindenki a maga ügyeit intézi. A procedúra pedig a gépeké. Az ember felszabadulhat a hivatalnoki robot alól, és kreatívabb irányba fejlôdhet, pl. ügyfeleket segíthet, szerzôdések programozását, tesztelését, hibajavítását végezheti. Ez nagyságrendekkel kevesebb munkaórát vesz igénybe, mint maga az ügyintézés. Gondoljunk arra, hogy egy hivatalnok minden ügy kapcsán szabályok ellenôrzésével tölti idejének jelentôs részét. Ez gépi feladattá válhat az okosszerzôdések idejében. Ezáltal tehát kielégíthetôvé válik a régebb óta közigazgatásban dolgozók azon igénye, miszerint munkájuk során szakértelmüket jobban szeretnék használni (Gellén, 2015). ${ }^{17}$ A DLT/blokklánc technológia alkalmazása bizonyos feladatkörök ellátása kapcsán tehát pontosan ennek tudna teret engedni a bürokratikus rutinfelada- tok elvégzésével. Értékteremtőbb, komolyabb szakértelmet igényló feladatokra felszabadítva a hivatali dolgozók kreatív potenciálját, teremtốrejét.

Ennek kapcsán érdemes megemlíteni Viktor Frankl nevét, aki a logoterápia megalkotójaként maga is a koncentrációs tábor túlélôjeként szerzett tapasztalatait jelenítette meg elméletében, mely egyenesen az élet és halál kérdését döntötte el megfigyelései szerint. Azaz, ố a logoszt, az emberi élet értelmességébe vetett hitet, ennek felfedezésére való képességet nevezi meg fó hajtóerônek, ami mint legbelsố mozgatórugó minden szenvedésen, nehézségen keresztülvivố hajtóerô, s adott esetben az élet és halál közti választóvonalat jelenti. Akik bármilyen módon komolyabb, mélyebb értelmet tudtak felfedezni személyes létükben, azok még olyan kemény megpróbáltatásokat, szenvedéseket is képesek voltak átvészelni, mint a koncentrációs táborok borzalmai. S megfigyelései alapján azok éltek túl, akikre ez a személyes értelemadás, személyes létükben valamiféle magasabb vezérelv, értelem, cél követése volt jellemzó. Kopp (2008) a nemzetközi boldogságkutatások alapján szintén döntố szempontként, kritériumként emeli ki az egyének, illetve közösségek boldogságszintjét alapvetôen meghatározó célorientáltságot, a megfeleló célok meglétét.

Már a klasszikus közgazdaságtan szerzôi is alapvetố szempontként emelik ki a munkavégzés minôsége kapcsán, hogy az vajon mennyiben létkiteljesítô, illetve csupán létfenntartó jellegú-e. Itt már ugyan lételméleti mélységeket érintünk, ugyanakkor a modern egészségpszichológia, pozitív pszichológia kutatási eredményei szintén ez irányba mutatnak, gondoljunk csak a fent említett Csíkszentmihályi flow 


\section{Tudományos múhely}

élményként definiált elméletére, amely egyszersmind összeér az ôsi bölcsességhagyományok legalapvetốbb tanításaival is. Az univerzális léttörvények alapján is ez lehet az emberi élet legfelsôbb célja, s tulajdonképpen részben az ilyen értelemben vett létkiteljesítô munkavégzés adja az emberhez igazán méltó lét alapjait, amely súlyának megfelelốen meg is jelenik az egyetemes emberi jogok között.

Tehát a komolyabb alkotómunka, teremtố potenciál kibontakoztatásának lehetôsége jó eséllyel hozhat egy újfajta dinamizmust a közigazgatás múködésébe, amely valószínúleg a hatékonyságot is jelentékeny mértékben növeli majd, a közigazgatás „átlelkesítése” által. Ehhez járulhat hozzá többek között technológiai segédletként a DLT/blokklánc technológia, illetôleg annak közigazgatás terén kiaknázható alkalmazási lehetôségei.

\section{Kivaánatos hivatali struktúrák, munkaszervezési elvek}

Érdekes megállapítása még a fent említett közigazgatásban dolgozók körében végzett kutatásnak, hogy a hierarchia és a szolgálati út betartása, valamint a feladatok delegálása iránti vágy szintén erősen jellemzi a közigazgatást, amelyet a kutatást végzók ellentmondásosnak ítélnek, mivel a valódi delegálás a hierarchia bizonyos fokú lebontását, módosulását vonhatja maga után, amelyhez azonban ragaszkodnak. Amint kifejtik a szolgálati út kérdésével kapcsolatban: „A delegálás növelése iránti vágy és a szakmaiság növelése iránti vágy a kormánytisztviselók körében nem eredményezte azt, hogy a hierarchia és a szolgálati út merev betartását ne tartanák fontosnak, miközben kirajzolódik az az ambíciójuk, hogy a döntéshozók szakmai partnernek tekintsék ôket. A partnerként való elfogadás itt nem egyenrangú feleket jelent, hanem a hierarchiában magasabban álló személy bizalmas odafordulását a hierarchiában alacsonyabban álló személyhez" (Gellén, 2015:111).

Gellén (2015) ebben a Max Weber-i közigazgatási kultúra mély beágyazottságát véli felfedezni. Jelen tanulmány szerzôi azt feltételezik, hogy ez egyszerre lehet igaz egy ennél mélyebb gyökerú „hittel”, meggyőzôdéssel, kulturális axiómával a magyar joghagyományokhoz kötődően. Wittgensteintốl kezdve számos gondolkodó próbálta fellelni, visszafejteni az ilyen legmélyebb „megkövesült meggyőzôdéseinket", vagy ahogy Wittgenstein maga fogalmaz, az európai kultúrkör fundamentális vélekedéseit. Jelen tanulmány a sajátosan magyar társadalomszervezési kulturális hagyományokra szorítkozik. ${ }^{18}$

E tekintetben tehát felmerülhet a kérdés, hogy vajon az elsố látásra talán Max Weber-inek túnố értékek nem azért tudtak-e beágyazódni és komolyabb hatást kifejteni, mivel valami ismerôs kulturális logikára, szervezóelvre épültek, mint a saját évezredes alkotmányosságunk, a Szent Korona jogrendje, amely olyan szerves állami, hatalomszervezési módot jelentett, amelyben mindent a törvényes jogosultságok rendszere szabályozott, s nem puszta vertikum alapján szervezôdố hatalmi viszonyok döntöttek a különbözó ügyek intézése kapcsán, hanem a törvényes jogosultságok rendje. Az ebbe vetett mély állampolgári meggyôzốdés, hit továbbélését is láthatjuk abban, hogy a közigazgatásban dolgozók ragaszkodnak a hivatali utakhoz, formális hierarchiához is, ugyanakkor bizonyos tekintetben vágynak is némiképp nagyobb mozgástérre, 


\section{Tudományos múhely}

ami a feladatok delegálása iránti igényükben nyilvánul meg.

Ennek megértéséhez segítségül hívhatjuk Karácsony (1939) A magyar észjárás címú múvét. Karácsony kifejti, hogy a magyar gondolkodásmódot $\mathrm{s}$ magát a nyelvünket, hatalomszemléletünket átható, mellérendelố szemlélet nem jelenti a különbözôségek (pl. szakértelembeli vagy hierarchiában betöltött fokozat) eltörlését, „a nem egyenlő mesterséges, múvi egyenlősítését”, ahogy Schmitt tömegdemokrácia-kritikájában fogalmaz. Sokkal inkább egy olyan szerves rendet, múködési módot, amelyben a hierarchia megtartásával mégis megvalósul egyben a mellérendeltség, egyenrangú méltóság elve is. Magát a hierarchiát is egy jóval inkább meritokratikus rendnek tekinthetjük, ahogy a hierarchia az eredeti értelmében szólt, tehát itt inkább egy érdemalapú hierarchiáról beszélhetünk, a puszta külsôdleges hatalmi viszonyokon alapuló vertikum helyett. ${ }^{19}$

$\mathrm{Az}$ államtörténeti gondolkodásban Zlinszky a következôképp fejezi ki ennek a sajátosan magyar, egyszerre hierarchikusan és mellérendelóen szervezôdó hatalomgyakorlási módnak a lényegét: „A törvényhozó hatalmat egységben, az igazgatási hatalmat osztottan, a központi hatalmat a király magyar báróin keresztül, a nemesek a helyi hatalmat gyakorolják, amely egyenrangú a központival szemben. Ez az osztott hatalom (helyi önkormányzat) a magyar jogban szintén sajátos dolog. Még törvénykihirdetési joggal is járt késôbb, tehát a helyi önkormányzat maga is vizsgálhatja, hogy alkotmányos-e az a törvény, amit együtt alkottunk. Az igazságszolgáltatást is megosztva, helyben a rendek, központban és a gyökeres jogok tekintetében a király gyakorolták.
Nemcsak egymás fölé épített igazságszolgáltatásról van itt szó, hanem hatásköri megosztásról." Tehát itt együttes joggyakorlatról van szó a másik két hatalmi ágban, pedig egymásmellettiség van. Ki-ki a maga illetékessége szerint gyakorolhatja ezeket a jogokat (Zlinszky, 1999:17-18; Szarvas, 2016a).

Ez a típusú államszervezési hagyomány múködésmódját tekintve a legújabb agykutatási eredmények fényében is a lehetô legteljesebb mértékben szerves szervezódési mód a természetben, de ugyanúgy az emberi agy múködésmódjára is jellemzó heterarchikus múködési elvet követ. ${ }^{20}$

\section{Állampolgárok egyedi azonositása és/vagy pedig elözetes ismeret nélküli, anonim jogosultság-ellenôrzés}

Az Ethereum-alapú igazgatási réteg a legújabb kriptográfiai eszköztárat vonultatja fel. Kiemelten fontos a „zéró ismereten alapuló protokoll" (ZKP), ami például arra szolgál, hogy névtelenül végzett tranzakcióról kiderüljön, hogy a kezdeményezônek van-e hozzá jogosítványa. Ehhez a kezdeményezốt egyáltalán nem kell azonosítani, csak a jogosultságát. ${ }^{21}$ Ilyen példa, hogy ha elvesztem a jelszóval lezárt mobiltelefonomat, és a megtalálónak igazolni akarom, hogy az enyém, akkor sem kell bemutatkoznom, nem kell megmondanom a jelszavamat, sem hazautaznom a számláért; elég belépnem a telefonomba, hogy a megtaláló elhiggye, az enyém. A belépés ténye igazolja a jogomat, nem a nevem vagy a jelszó megadása, vagy számla felmutatása.

Ennek komplex példája a személyi okmányok DLT/blokklánc technológián történô kezelése. A technológia a hamisíthatatlanság és minden módosulás örök 
megőrzése által teljesen hiteles forrása minden anyakönyvi, végzettséget és jogosítványokat igazoló adatnak, és persze kórtörténetnek, pénzügyi tranzakcióknak stb. is. Az állampolgárnál egyetlen személyi azonosító kártya vagy mobiltelefonos „pénztárca” van, és a jelszó, amelylyel a kártyájának/pénztárcájának kulcsait elôveheti, és minden személyes adatát egyenként kiadhatja annak, akinek ô szeretné. Jogosultságait pedig titkos adatai kiadása nélkül ellenôrizheti a hatóság, hiszen a ZKP-technológia lehetôvé teszi az adatok megismerése nélkül csak a jogosultság ellenôrzését. Még egyszerú beléptetésnél sem kell a kilétünket felfednünk, csak a belépési jogosultságunkat bizonyítanunk. Ez minden jogosítványra igaz a gépjármúvezetéstôl a receptfelírásig. Ez csak egy példa a számos lehetséges e-kormányzati alkalmazásból. ${ }^{22}$

\section{Alkalmazási lehetôségek a Nemzeti Adó-és Vámhivatal szolgáltatásfejlesztésében - E-számlázás helyett?}

A DLT/blokklánc technológia adóhatóság szempontjából releváns jellemzóje, hogy egy erre alapozott fizetési vagy pénzrendszer nem igényel számlázást, hiszen maga a fôkönyv nyilvános. Az anonimitás miatt még annak ellenôrzésére is szükség van, hogy az adót befizettem-e. Nem szükséges, hogy a hatóság könyveljen, csak az, hogy minden tranzakció adóvonzata be legyen fizetve. Figyelembe veendô a járulékok önkéntes fizetésének lehetôsége, a kedvezmények, adónemek közti választási lehetôségek is, sốt az adó 1+1\%-áról való rendelkezés lehetôsége is. Mindez teljesen anonim módon megoldható az önmúködô szerzôdés, a zéró ismereten alapuló protokoll (pl. információt nem közlô adóigazolással) alkalmazásával, valamint az új kriptopénzrendszer szabályainak eredeti felépítése által. A legutóbbi, azaz új nemzeti kriptodeviza bevezetése a legkézenfekvôbb lehetôség egy állam számára. Erre a mai utalványrendszer vagy az egészségügyi pontrendszer már egy előzetes példa. Ez a teljes közigazgatás belsố elszámolási rendszerére is kiterjeszthetô lehetne már ma. Továbbá nemzeti deviza és helyi pénzek kapcsán is nagyon idôszerú lenne komoly diskurzust indítani.

\section{Alkalmazási lehetôségek hadászati ellátási láncban ${ }^{23}$}

A logisztika a közigazgatásban alapvetô fontosságú. Akár általában ellátási láncról (közbeszerzés, szétosztás, követés/szerviz, amortizáció, felhasználás), akár hadászati logisztikáról van szó, a feladat hasonló. A hadászat ellátási lánca rendkívül szerteágazó, mégis teljesen integrált módon kell kezelni. Ahol a védelmi feladat megköveteli, embert, élelmet, szállást, ruházatot, személyi felszerelést, gyógyellátást, múszaki eszközt, mindezek utánpótlását muszáj biztosítani. Gondoljunk arra is, hogy a hadászat több száz fajtájú, sok forrásból származó (hazai, szovjet stb.), évtizedekig hadrendben álló múszaki eszközt tart készleten. Ezek szervize, fenntartása, az idô közben megszúnt beszállítók pótlása, az idôk során felújított, módosított, amúgy is több változatban létezô konstrukciók régi alkatrészeinek kivezetése, újak bevezetése mind-mind hibák (hiányok és feleslegek felhalmozódásának) forrása. Kezelendó a hadászati eszközök mozgatása, elhasználódása, sérülése, megsemmisülése, elvesztése, fogyó alkatrészek és anyagok ellátása is, és ezek is az ember számára sok hibalehetôséget 
tartogatnak. A múszaki eszközök gyorsan változtatják a helyüket, és a szervizt, javítást gyakran a helyszínen kell elvégezni, oda épp a megfelelő személyzetet és alkatrészt kell vinni.

Hasonlóan problémás az élelmezés, annak biztonsága, ételallergiák figyelembevétele, az ételek készletezése, tárolási követelményei, lejárati idôk figyelembevétele. ${ }^{24}$ Ennél bonyolultabb a gyógyszerek, kötszerek, egészségügyi eszközök biztosítása, tárolása, lejárati idôk, gyógyszerérzékenységek, kórelôzmények figyelembevétele, gépek alkatrészeinek utánpótlása, szervizelés stb.

Jelenleg központi adatbázisrendszerek tárolják e logisztikai adatokat. Ezek a központiságuk miatt sebezhetőek, a hozzáférés biztosítása pedig rendkívüli körültekintést igényel, néha pedig épp a szükség idején szünetel az elérés. További probléma velük, hogy egyedi termékek, ezért egymással nehezen és hibák árán integrálhatóak. Ezzel szemben a DLT/ blokklánc egy szabványos fókönyvformátum, ami konkrét bizonylatokat tárol. Ahhoz, hogy OLAP-analitika vagy ember számára értelmezhetô legyen, a konkrét bizonylat azonosítása és a dimenziók kellenek. Az elsôhöz (bizonylatazonosítás) csak a jogosultnak vannak adatai, a második (dimenziók) pedig egységesíthetô nemzeti vagy akár NATO-szinten is. A rendszer logikája szabványos önmúködô szerzôdésekben kezelhetô. Látható tehát, hogy az adatmodellszintú integráció jelentôsen kisebb probléma, mint egyedi adatmodellek esetén. Az egyszeri, teljes átállással viszont számolni kell.

Erre az infrastruktúrára már nagyon sok informatikai fejlesztô cég képes szoftvereket elôállítani, és pl. az OLAP-analitika már ma is sok forrásból beszerezhetô.
Az, hogy sok forrásból kerülhet szoftver a honvédségi eszközparkba, versenyt, jó árakat, jobb tárgyalási pozíciót és lecserélhetôséget hoz. További eloony, hogy apróbb feladatokat lehet pályázatokban meghirdetni, amelyek elkészülési ideje sokkal rövidebb. Az egyes beszállítók is kevésbé jutnak kényes információhoz, hiszen nem látják a rendszer egészét, esetleges gyenge pontjait.

A hagyományos logisztikától a hadászat még egy fontos dologban tér el. Nem lehet nyilvános. Mégis nyilvános elosztottfőkönyv-technikát javasolunk az irányítására. Erre is született informatikai megoldás: a privát és a hibrid DLT. A közbeszerzési és más nyilvános tételek maradnak nyilvánosak és globálisan tároltak, a katonai mozgások tranzakciói pedig sok, védett katonai objektumban, rejtjelesen is védve tárolódnak, kétszeresen elzárva az illetéktelen szemek elól. Így a sokközpontúság és a rejtettség egyidejúleg érvényesül.

A DLT/blokklánc alapú hálózat olyan összetett megoldás, ami elosztott üzenetküldô, transzparens és rendkívül megbízható validáló, könyvelô és adattároló egyszerre, kitûnô és egyre fejlettebbre cserélhetô biztonsági módszerekkel. Tranzakció-feldolgozó képessége ma is elegendố a katonai logisztika és üzenetek kezelésére, és folyamatosan növekszik. A kormányzati és a katonai kommunikáció biztonságosabbá, öndokumentálóvá és hozzáférhetôbbé tehetô DLT/blokklánc alapú kommunikációs megoldásokkal. ${ }^{25}$

A DLT/blokklánc szabványos formában tárolja a logisztika minden eseményét, bizonylatát, ezért kiváló forrása a dimenziós analitikának (OLAP), amit elterjedten alkalmaznak ellátási láncok 


\section{Tudományos múhely}

javítására. Például mivel minden egyes tranzakció visszakereshetô, elemezni lehet a gyártók, szállítók, áruk, szállítási csatornák megbízhatóságát, képességeit, lehet rendelkezni a fejlesztésükrôl, bôvítésükrôl, kiváltásukról. Ha gépi szabályok végzik az ellátás vezérlését, az csökkenti a szervezési hanyagság, korrupció miatti hibákat is. A kormányzati és hadászati beszállítók közül gyakran azért maradnak ki kisebb vállalkozások, mert nem tudják teljesíteni a bürokratikus elvárásokat. Ezt átveszi tôlük a rendszer, a kis cégeknek csak végre kell hajtani, amit a rendszer által a kormányzat megkövetel, így nô a beszállítói verseny, és csökken az ár. Ha pedig a nagyvállalatok is alkalmazkodnak, akkor a teljes átláthatóság és a bizalom is javul.

$\mathrm{Az}$ informatikai eszközök használatához a motiváció elengedhetetlen. Ennek több formája van. Lehet a kényszer (munkahelyen), lehet az eszköz által nyújtott kényelem, illetóleg az is, hogy sokkal több elóny származik belóle, mint kényelmetlenség. ${ }^{26} \quad \mathrm{~A}$ közigazgatásban az elsố és az utolsó a meghatározó. Az utolsó, a megtérülés az, ami a hivatalnok számára lelkesítô lehet. A motiváció tulajdonképpen a blockchain belsô sajátja is. A munkát végzố csomópontok kriptopénzt kapnak a munkájukért. A kriptopénznek értéket ad, hogy dolgoztak érte, és más motivációkkal a kriptopénz a reálgazdaságban is piacot teremt magának. A motivációk által vezérelt, piacosított világba csöppenünk általa. Az adózás újragondolását is ki fogja kényszeríteni ez a gondolkodásmód. A szolgáltató állam felé tett éles kanyar bevezetôjébe kerültünk. Az államnak többé nem azon kell gondolkodnia, hogyan szabályozza és nehezítse a pénzmúveleteket, hanem azon, hogyan állhat az élükre, és válhat piaci szereplôvé újból. A motiváció akkor jelenik meg, amikor a munkát elvégzô úgy éli meg, hogy megéri. Erre anyagi, szellemi, pszichés, érzelmi, esztétikai stb. téren van lehetôség. A számítógép használatához hasonlóan az adózásról is kialakulhat jó kép jó visszajelzések esetén. Az említett tanulmányunkban a részvételi költségvetés motiváló erejét fejtettük ki (pl. az adóm valahány \%-át egy játszótér építésére rendeltem, ami megépült).

Amint arra Nemeslaki (2016) is utal, az IT-újítások nem kezelhetôek önmagukban álló területként, annak szociotechnológiai beágyazódásának tekintetbevétele elengedhetetlen a technológiák tényleges bevezetéséhez. Ezeknél is lényeges tehát a megfelelố motivációk, ösztönzók figyelembevétele, annak tudatosítása tehát, hogy itt olyan társadalmi-technológiai rendszerekrôl van szó, amelyekben számos perspektíva, számos különbözố hátterú és érdekú szereplố vesz részt. Az emberi tényezôt, humán és technológiai folyamatok egymást átszövố rendszerét egyben kezelô multiaktor- vagy társadalmi-technológiai rendszerszemlélet alkalmazását javasolja tehát. Az IT és üzleti élet együttmúködéseinek sikerességét meghatározó hat tényezô, kritérium tekintetbevételét veti tehát fel, mint amely a közigazgatás és IT terén létrejövố együttmúködésekre is alkalmazható némi kiegészítéssel, kontextuális illeszkedéssel. Ezek röviden: a kommunikáció jelentôsége, a közös nyelv megtalálása a különbözô szereplók között; kompetencia, illetve mérórendszerek, mutatók alkalmazása a különbözố területek célrendszeréhez igazodva (példaként felhozza a Jó Állam mérôrendszerét, amely hat hatásterületen 30 indikátort alkalmaz.) Lépték, arányok és megfelelố architektúra; az ember és 
gép közti mindennapossá váló interakciók, viszony mint életjelenség kezelésére. Hogyan tudják kezelni adott esetben a közigazgatásban dolgozók ezt a mai valóságból kivonhatatlan interakciót, kölcsönhatást a virtuális eszközökkel, rendszerekkel. A további három kritérium pedig az irányítórendszerek, partnerség elve (bizalom, egyenrangúság, rugalmasság), végül pedig a készségek, készségek fejlesztése, amelybe beletartozik, hogy miként tesszük képessé az ott dolgozókat az eszközök elfogadására, használatára, milyen tréningeket szervezünk, az oktatás szemlélete mennyire inspirálja az eszközök használatát (Nemeslaki, 2016).

\section{Kriptopénzek - a nemzetállamok} versenyképességének záloga az új világrendben

Világszerte azt tapasztaljuk, hogy a nemzetállamokat immáron létükben fenyegetik a magánhatalom, a különbözó globális üzleti csoportok és ezek minden ideológiai terméke. Az állam akkor maradhat fenn, és akkor lehet képes a nemzet védelmére, ha még most lép, és a minden eddiginél kiélezettebb piaci verseny és hatalmi verseny erôs résztvevôjévé válik. A kriptopénzre mint az új helyzet megkerülhetetlen alakítójára érdemes rátekintenie, és élére állni a változásoknak. A magánhatalom olyan eszközt állított elô a kriptopénzekkel, amely az állam számára többé nem szabályozható, mert nem ismer országhatárokat, nem uralható, és kizárólag piaci, tôzsdei elvek mozgatják. Az államnak most nincs más lehetôsége, mint hogy maga is nyerjen ezen az új versenypályán, az új szabályok közepette. A jelenlegi MNB-politika is már a piaci szabályok melletti verseny irányába tett határozott elmozdulást, és szemlátomást sikeresen. A kriptopénzrendszer újabb lehetôség nemzetünk számára, hogy új pályán szálljon be a gyôztesek közé.

A közösségek számára a legfóbb gond a hatalmi központok (politikai, magánhatalmi) általi befolyásoltság. A blockchainrendszer nem hamisítható, tehát technológiailag nem befolyásolható, cenzúrázható. Ezért a politikai kommunikáció és a közösségeken belüli kommunikáció számára is jó eszköz lehet. Az üzleti szférában már meg is jelent ez a csatorna, hiszen jogi, cégen belüli, cégek közötti kommunikációt is lehet rá alapozni. A befolyásolhatatlanság egyben jogi alapot is teremt arra, hogy az így történt megbeszélések, megállapodások, tartalmak maguk is jogi erôvel bírjanak.

Egy informatikai rendszer a többi, hasonló rendszerhez mérve számít jobbnak vagy rosszabbnak, és itt figyelembe kell venni mindent, ami eddig létezett, kezdve a papíralapútól a központi szerveres megoldáson át az elosztott architektúrájú rendszerekig.

\section{DLT/BLOKKLÁNC TECHNOLÓGIÁK EGÉSZSÉGÜGYI ALKALMAZÁSAI}

2016-ban azt láttuk, hogy a pénzügyi szolgáltatások terén a beruházások hatalmas hulláma irányult a DLT/blokklánc alkalmazásfejlesztésekbe. ${ }^{27}$ Az idô múlásával, ugyanezzel a lendülettel az érdeklôdés átragadt a pénzügyi alkalmazások világából a többi iparágba is, és nagy erôkkel megindultak a fejlesztések az egészségügyi alkalmazások területén is. Az IBM elemzései és felmérései ${ }^{28}$ szerint az egészségügyi intézmények 16\%-a arra számít (16 országban 200 intézmény megkérdezésével végzett tanulmány), hogy az üzleti DLT/ 
blokklánc alkalmazások jelentôs szerepet töltenek be a következó években. A technológia az elórejelzések szerint 2020-ra jelentôs mértékben elterjed, és ezt követôen már csak kullogni lehet az események után.

Az egészségüggyel foglalkozó szervezetek nagy része felismerte, hogy mind kifizetôi, mind pedig szolgáltatói oldalon a DLT/blokklánc alkalmazása jelentôs elônyökkel jár. Különösen az operatív vezetốk látják, hogy a DLT/blokklánc technológiák nyújtotta decentralizációs, biztonságos kétoldalú egyezségeken alapuló, okosszerzôdésekkel támogatott tranzakciók képesek jelentôsen csökkenteni az adminisztratív költségeket, miközben az ellátási folyamatokat és azok finanszírozását nagymértékben, közel valós idôben tudják biztosítani. Egészségszakmai szempontból az adatok tagolt, elosztott kezelése azonban szignifikáns mennyiségú extra erôforrást igényel. A potenciális alkalmazási területek közül ki kell emelni hármat, melyekkel részletesebben is foglalkozunk, ezek: a klinikai gyógyszerkutatások területe, az egészségügyi ellátás szabályozásának ellenőrzött végrehajtása és az orvosi kórtörténet általánosított kezelése.

Ma már az egészségügyi adatok nagy része digitális formában jelenik meg, ugyanakkor ezek felhasználását jelentôs mértékben korlátozzák a technikai nehézségek és az extenzív szabályozások, valamint a megosztással járó kockázatok. Felmérések szerint pontosan ezek a tényezók hatnak a meglévố információk hatékony felhasználása ellen a következô formákban:

- helytelen információk, amelyek miatt fóleg az adatok utólagosan, a keletkezési idôtốl eltérố idôben keletkeznek vagy módosulnak;
- információs kockázatok, mely szerint a megosztott adatok viszonylag könnyen kerülhetnek illetéktelen kezekbe;

- elérhetetlen információk, amelyek fóként izolált informatikai rendszerekben keletkeznek és tárolódnak, mint nem integrált diagnosztikai és terápiás szolgáltatások, vagy egyszerúen korszerútlen informatikai alrendszerek.

A felsorolt három informatikai adatkezelési probléma megoldása nagymértékú koordinációs ráfordításokat és az együttmúködési technikák fejlesztését igénylik. A személyiségi jogok, valamint a jelen lévố internetes támadások tovább nehezítik az adatcsere és információ hozzáférési kérdéseit. A megosztott adatok esetén, amikor a megosztás módja, mely pillanatnyilag elsôsorban papíralapú, és melyen a kialakításra került EESZT (Egységes Egészségügyi Szolgáltatási Tér) ugyan fontos minôségjavulást ígér, az adatok többszöri manuális rögzítése gyakori hibák forrása. Az adatok ellenôrzése, különös tekintettel az ismételt vizsgálatok gyakori előfordulására, jelentôs többletköltséggel és késedelemmel jár. Megemlítendő, hogy a növekvố magánegészségügyi szolgáltatások, privát diagnosztikai laborok, képalkotó eljárások, magánorvosok, magánkórházak által előállított adatok központi integrálása bonyolult és igen költséges, valamint a szolgáltatóknak nem feltétlenül érdeke az integrációhoz szükséges terhek vállalása, ami szükségképpen feszültségekhez vezet, ezért itt is szükséges az integrációs költségek jelentôs csökkentése és valamiféle érdekeltség megteremtése.

A DLT/blokklánc technológiák alkalmazása mindhárom területen jelentôs elôrelépést jelenthet. A technológia képes garantálni az adatok keletkezési idô- 
ben történố rögzítése esetén azok sérthetetlenségét és megváltoztathatatlanságát, ezen adatok késôbb nem változtathatóak meg, az adatokon végrehajtani szükséges korrekciókat minden esetben rögzítik a DLT/blokkláncon, mindenki számára ellenôrizhetố módon. Az információs kockázatokat a kriptográfia eszközeivel biztosított eljárások elméletileg teljesen kizárják. Rendszerhibák természetesen ekkor is elófordulhatnak, azonban a célzott kibernetikai támadások esélye elhanyagolható mértékúre csökkenthetô. A megfelelô titkosítási eljárásokkal védett adatok felfedése elleni támadások DLT/blokkláncon tárolt adatok esetében lényegében ismeretlenek. Ugyancsak ismeretlenek a DLT/blokkláncok ellen elkövetett DoS (Denial of Service) típusú támadások, ${ }^{29}$ amikor a szolgáltatást valamilyen elárasztásos technikával próbálják lehetetlenné tenni, blokkolni, oly mértékben leterhelve a szervereket, hogy azok képtelenek a hozzájuk intézett kérdésekre válaszolni. A DLT/blokklánc elosztott, pont-pont struktúrájú hálózata esetén nincs támadható központi szerver, ezért az ilyen típusú támadások esélye csekély, mivel a támadás költsége óriásira multiplikálódik. Az információk elérésére a DLT/blokklánc technológiák a nyílt hozzáférés biztosításával és az információ egyszerú szerkezetú tárolásával válaszolnak. A DLT/blokklánc technológiák esetében az adatok tárolása meglepő́n egyszerú, már-már primitív. A központosított adatbázis-technológiák meglehetôsen bonyolult adatszerkezeteivel szemben a DLT/blokklánc adatszerkezetek egyirányúak és egyszerúek. A DLT/blokkláncon tárolt adatok leírhatóak egy (név, adat) párral, amihez tranzakciónként néhány rögzített tartalmú kiegészítố adat társul, amik a tranzakciós idôpontokat és a lineáris blokkszerkezeteket biztosító kriptográfiai kulcsokat tartalmazzák.

A DLT/blokkláncnak pillanatnyilag nem létezik általánosan elfogadott definíciója. Ugyanakkor minden meghatározási próbálkozás említi a következô tulajdonságokat és sajátosságokat (Narayanan et al., 2016), melyeknek együtt kell jelen lenniük ahhoz, hogy DLT/blokkláncról beszéljünk:

- elosztott adatbázis, mely tranzakciós rekordok meghatározott csomagjait egy blokkba foglalva, a blokkot valamilyen eljárással véglegesítve egy növekvô, összefüggó láncot képezố adatszerkezetet hoz létre;

- a DLT/blokkláncot ekvivalens csomópontok tárolják és kezelik, adatlekéréssel a csomópontok bármelyikéhez lehet fordulni;

- a csomópontok között nincs kiemelt, központi szerepet betöltô csomópont, így egy-egy csomópont kiesése vagy új csomópontok belépése a pont-pont hálózatba mindenkor megengedett;

- a tárolt adatok tartalma minden egyes csomóponton megegyezik, amirôl egy egyeztetési, ún. konszenzus ${ }^{30}$ protokoll gondoskodik.

A DLT/blokklánc adatszerkezetek kezdettốl fogva tartalmaznak egy adatkezelési mechanizmust, ami nem tartozik szorosan a DLT/blokklánc fogalmához, de minden gyakorlatban előforduló jelentósebb DLT/blokklánc technológia része. Az adatkezelési mechanizmus lényegében egy több-kevesebb lehetôséggel ellátott programozási nyelv vagy scriptnyelv, mellyel adatkezelési utasításokat írhatunk elô. Az adatkezelési utasítássorozatok segítségével okosszerzôdéseket lehet létrehozni. 
A DLT/blokkláncon történô mindennemú interakció minden csomópont számára ismert, és megköveteli, hogy a tárolást megelőzóen egy verifikációs eljárás hitelesítse az adatokat, mielőtt azok véglegesen a DLT/blokkláncba kerülnek, ez a mechanizmus megteremti a bizalommentes együttmúködést két fél között. Bizalommentesnek nevezünk egy együttmúködést, ha nincs szükség harmadik, közvetítô félre olyan tranzakció végrehajtásához, melyben az együttmúködő felek bármelyike nem tisztességes viselkedés esetén jogtalan előnyhöz juthatna. Más szóval, a DLT/blokkláncon végrehajtott tranzakciók esetén nem lehet a felállított tranzakciós szabályokat kijátszani. A DLT/blokklánc e tulajdonsága kiküszöböli a közvetítôket - legyen az jogi vagy technikai - a közvetlen együttmúködés során. A harmadik fél, azaz a közvetítô kiküszöbölése rendkívül jelentôs erőforrás-megtakarítással jár. A harmadik felet, mely egy-egy pénzügyi tranzakció során mindig jelen van explicit vagy többnyire implicit formában (pl. állami garancia, jogi kényszerítô eszközök, bank, letétkezelô stb.), a DLT/blokklánc technológiák esetében helyettesíti maga a hálózat, avagy a korábban említett múködtetô közösség.

A DLT/blokkláncon végrehajtott tranzakciós múveletek alapvetôen négy lépésból állnak:

- Az adott egészségügyi entitás (szolgáltató, szervezet, személy) elhelyez egy adott információt, például egy végrehajtott szolgáltatás leírását, a klinikumban keletkezố adatok tárolódnak a lokális klinikai rendszerekben. A standardizált adatmezốk - alapvetốen (név, érték) adatpárok - a páciens publikus kulcsával azonosítva átirányításra kerülnek a DLT/ blokkláncra, amihez szabványos eljáráshívások állnak rendelkezésre.

- A tranzakció - egészségügyi alkalmazások esetén minden szolgáltató-beteg interakcióban adat keletkezik - felkerül a DLT/blokkláncra. Mind a páciens, mind pedig a szolgáltató publikus kriptográfiai kulcsokkal azonosított. Az azonosítás maga történhet egy külön DLT/blokkláncon, ahol az információ védelmét tovább lehet fokozni, és további létezô kriptográfiai eszköztárat lehet alkalmazni (vak aláírás, megosztott kulcsok, hierarchikus kulcsok, többszörös aláírások használata, „zero knowledge proof” technikák) alkalmazása. A megbízható (bizalommentes) adattárolás miatt, csak a szabályoknak megfelelô adatok kerülhetnek be az adatbázisba, ennélfogva egy sor auditálási és keresztellenôrzési tevékenység feleslegessé válik, ami újabb erőforrások felszabadítását teszi lehetôvé.

- Az egészségügyi entitások közvetlenül lekérdezik a DLT/blokkláncot, ha adatra van szükségük. A kérdezók itt is megfeleló eljárásokon keresztül férnek hozzá az adatokhoz, miközben az elvégzett múveletek naplóba kerülnek. Az egészségügyi adatok személyiségi jogi szempontból kiemelten nagy kockázatot jelentenek, ezért az ágazatra jellemzô, speciális eljárások alkalmazása szükséges. A lekérdezések a publikálást megelôzően alkalmas szúrôkön vagy az okosszerzôdésekbe épített alkalmazási logikán keresztül hajthatóak végre, hogy a személyiségi jogi rendelkezéseknek megfeleló adatokhoz lehessen csak hozzáférni.

- A páciensek a privát kulcsaik felhasználásának engedélyezésével járulnak hozzá adataik eléréséhez. A privát kulcsot átadva a kezeló intézménynek, az intézmény képes elérni a páciens személyes 


\section{Tudományos múhely}

adatait. Itt azonban nem szükséges a páciens eredeti privát kulcsának megosztása - ez alapvetô biztonsági kérdéseket vetne fel -, elegendô egy hierarchikus kulcs idóben korlátozott használatára feljogosítani a szolgáltatót. A páciens adatai továbbra is hozzáférhetetlenek maradnak az illetéktelenek számára.

Az elmúlt, de különösen a 2017. évben számos tanulmány jelent meg a DLT/ blokklánc technológiák egészségügyi alkalmazását elemzendô. Az elemzô intézetek közül meg kell említeni az IBM-et, a Deloitte elemzóóriást, a Forbes magazint, az ausztrál és az észt kormányokat. Ezek az intézmények megnyitották azokat a tudományos, politikai és gazdasági csatornákat, melyeken keresztül a technológia alkalmazhatóságának kutatása immár jelentôs erôkkel folyik. Az elemzések az alábbiakban ismertetendô területeket sorolják fel.

\section{DLT/blokklánc a kórtörténetben}

Az orvosi kórtörténet a teljes egészségügyi ellátórendszer esszenciája. Leegyszerúsítve, a kórtörténet az az orvosi dokumentum, amely tartalmaz a páciensekról valaha rögzített minden adatot. Természetesen illúzió lenne azt gondolni, hogy bárkinek is létezne teljes és hiánytalan kórtörténete (éppenséggel egy újszülött esetén elképzelhetô lenne, de a családi anamnézis hiányosságai ezt a feltevést máris negálják). Az ellátórendszer természetéból fakadóan az adatok elosztott módon keletkeznek, és hosszú távon, a páciensek idő- és térbeli mozgása folytán tagoltan tárolódnak. Sok esetben a személyes azonosító rendszerek hiánya vagy e rendszerek idôszakos cseréje miatt az adatok egymáshoz rendelése lehetetlen (például Magyarországon a rendszervál- táskor alkotmányellenessé vált személyi szám kiiktatása következtében a teljes AIDS-monitoring-nyilvántartás megszúnt - fürdővízzel a gyereket, nem először...). A személyhez kapcsolódó adatok központi nyilvántartása, különösen egészségügyi adatok esetén, számos jogi kérdést vet fel. Egészségügyi adatok esetén az adatok központi tárolása különösen érzékeny terület, amelynek következtében az egészségügyi fejlesztések akár éveket is késhetnek, amíg a megfeleló szakemberek és a jogalkotók egyezségre jutnak egyegy részmegoldást illetôen. Mindemellett hiába jönnek létre jogi megoldások a központosított tárolásra, előbb-utóbb magáról a szabályozásról derül ki annak tarthatatlan volta.

A DLT/blokklánc technológia ezen a területen forradalmian új megoldásokat kínál úgy, hogy a létezô rendszereket és befektetéseket megtartva, a kommunikáció új, biztonságos formáit lehet alkalmazni. A DLT/blokklánc megoldások a kriptográfiai eszközök intenzív használatával képesek a személyiségi jog szabályainak betartásával fenntartani a kommunikációt. Az érzékeny adatok központi tárolása mindig visszatérô problémákat fog okozni, különös tekintettel arra, hogy a végrehajtó hatalom szándékait illetôen hosszú távú garanciákat nem lehet adni.

$\mathrm{Az}$ egészségügyi adattárolás kérdéseinek megoldása területén megint Észtországot kell megemlíteni, ahol egy különleges, úgynevezett kulcsmentes kriptográfiai megoldással kezelik az észt lakosság adatait. Az észt esetben sok fontos problémát oldottak meg, a kulcsmentesség bevezetésével - ami lehetetlennek tûnô megoldásnak látszik - a páciensek privát kulcsát maga az egészségügyi hálózat helyettesíti nem visszafejthetô, teljesen 
biztonságos módon, nem adva esélyt semmiféle késóbb esetlegesen megjelenô malignus erônek illetéktelen hozzáférésre.

A kórtörténet szoros összefüggésben van az egészségügyi finanszírozással is, mióta a finanszírozás egyre inkább eltolódik a kimenetalapú finanszírozás felé. Természetesen továbbra is jelen vannak a szolgáltatásalapú, illetve az átalányalapú finanszírozási formák. Bármely finanszírozási sémát is alkalmazzuk egy adott területen, a DLT/blokklánc alapú megoldások tulajdonsága, hogy az események történetiségét szigorúan megốrzi, azon a változtatást nem teszi lehetôvé, így pontosabb adatok alapján lehet a kifizetéseket kiutalni. További nyereség a rendszerben, hogy a rögzített adatok és a valóság közötti eltérések jelentôsen csökkennek. Egyszerúbben megfogalmazva, nehezebb csalni.

A DLT/blokklánc technológia erôs konkurenciát jelent a jelenleg múködó egészségügyi információcsere- (Health Information Exchange, HIE) megoldásokkal szemben. A HIE-rendszerek jelenleg nem jelentenek áttörést, relatíve kevés helyen léteznek az Unión belül, és ahol léteznek, ott is csak néhány intézmény részvételével, a kialakítások saját protokollok alapján, technikailag bonyolult illeszkedési felületeket biztosítanak.

\section{DLT/blokklánc a klinikai kutatásokban}

Minden idôben emberek százezrei vesznek részt valamely klinikai kutatásban, ahol új eljárások vagy új gyógyszerek, vagy más innovatív kutatás kipróbálása történik. A klinikai kutatások rendszerint két alapvetố problémával szembesülnek: az egyik a megfelelố célcsoportok (pácienscsoportok) kiválasztásának nehézségei, a másik pedig a beérkezô adatok validitása. Hasonlóan a kórtörténetben említett adatmanipulációkhoz, ezen a területen is ismert jelenség az adatok manipulálása. Ennek okait nem vizsgálva, a DLT/blokklánc alkalmazása egyfelốl csökkenti vagy akár meg is szünteti a csalás lehetôségét, másfelól a keletkezố adatok magát a kórtörténetet is kiegészítik.

A felmérések szerint (IBM) ezen a területen volt mérhetô a legnagyobb várakozás a technológiával szemben mind szolgáltatói, mind pedig finanszírozási oldalon. A klinikai gyógyszerkipróbálásokat vizsgálva egy felmérés szerint 67 vizsgált esetból 9 (13\%) esetben lehetett megállapítani, hogy korrekt eredmények születtek. Nyilvánvaló, hogy a hamis adatok alapján levont következtetések eredményeképpen mindannyian végül is veszítünk.

\section{Számlázás és egészségügyi biztositás}

Nem meglepó módon a várakozások a pénzügyi területen magasak. Egyfelól a biztosítók valóban az elvégzett vizsgálatok, diagnózisok és alkalmazott terápiák alapján fizetnek, ugyanakkor az elszámolási procedúra a garantált adatminôség miatt jelentôsen felgyorsul, és a redukált ellenốrzési szükségletek miatt olcsóbbá is válik, ami mindkét fél számára elônyös. Természetesen az adatmanipulációk jelentôs csökkenése miatt az egyes szolgáltatások árstruktúrája a rendszerek belsố dinamikája következtében módosulni fog.

\section{További kiemelt alkalmazási területek}

Az irodalmi hivatkozások közül kiemeljük azokat a területeket, melyeket a felmérések potenciális célpontként említenek: 
- Okoseszközök integrációja, az IoMT(Internet of Medical Things) eszközök mérési eredményeit jelenleg egyáltalán nem vagy alig lehet bevonni a diagnosztikus, terápiás és monitorozási folyamatokba megfelelố azonosítási eljárás és integrációs hiányosságok miatt. A hordozható okoseszközök viszont egyre nagyobb szerepet kapnak az egészségmegőrzés, illetve az állapotkontroll-folyamatokban (digitális vérnyomásmérôk, cukorszint-, mozgás-, keringésmonitorok, biometrikus méróeszközök stb.).

- Vagyonnyilvántartás, a decentralizált eszközbeszerzések követése és liberalizálása válik lehetségessé az intézményi költségvetés veszélyeztetése nélkül, miközben a szükséges eszközök gyorsabban használatba vehetôk. A beszerzési folyamatok jelentôsen egyszerúsíthetôk és felgyorsíthatók, ami ellátási szempontból egyértelmúen kívánatos, miközben likviditási szempontból gondos tervezést és szabályozást von maga után. A nagy értékú eszközök által elérhetố kapacitások egyszerre jelennek meg minden szolgáltató számára.

- Szerzôdés-nyilvántartások, az okosszerzôdések révén a szerzôdött szolgáltatások követése hatékonyabbá válik a perifériákon történố események adatainak közvetlen, közel valós idejú követésével, és mind a biztosítási szerzôdések, mind pedig a beszállítói szerzódések vezérlése megoldható.

- Gyógyszerelések és kezelések követése. A DLT/blokklánc decentralizált természete, valamint az okosszerzôdések alkalmazása új távlatokat nyit a terápiás eljárások követésében és tervezésében.

- A törvényes múködés kikényszerítése az okosszerzódések intenzív alkalmazásával.
- Mellékhatások és gyógyszer-interakciók hatékonyabb elkerülése azáltal, hogy a különbözô szolgáltatók ugyanazon DLT/blokkláncon hajtanak végre múveleteket, melyeket megfelelő okosszerzódés-konstrukciókkal lehet automatikusan ellenórizni.

Mindamellett, hogy a DLT/blokklánc technológia a felsorolt területeken jelentős elônyökkel jár, nem rövid távon várható áttörés. A technológia jelenleg kiforratlan, túl gyorsan fejlódik, jobbára kipróbálási és tapasztalatszerzési szakaszban van, pillanatnyilag kevés a hozzáértô szakember (ami jó kitörési pontot jelent a korai befektetőknek), tisztázatlanok a szabályozás lehetôségei, nem egyértelmúek a befektetések megtérülési mutatói, és nincs elegendô alkalmazási példa. Ennek ellenére az elkövetkezô idôszakban számos fejlesztés készül, és az eddigi eredmények alapján megkezdódik az alkalmazások gyorsuló ütemú megjelenése. A kockázatok és lehetôségek egyenlege a technológia fejlődésének irányába mutat, vagyis az a helyzet áll fenn, amikor sokat kockáztatnak, vagy nem kockáztatnak. Különbözô elôrejelzések készülnek, melyek mindegyike a technológia exponenciális növekedésével számol középtávon.

\section{KONKLÚZió}

Az már most is látható, hogy új korszak, a globális, de elosztott tranzakciókezelés korának kapujában vagyunk. Olyan infrastruktúra került a gazdaság szereplőinek kezébe, amely kizárólag saját szabályait ismeri, és nem könnyen kényszeríthetô rá állami korlátozás. Ám e saját szabályokat maga az állam is megalkothatja. Az állam akkor lesz képes fenntartani a jogállamiságot és közösségi jóllétet biztosító szerepét, 


\section{Tudományos múhely}

ha maga is felkészülten lép át ebbe a korszakba, és a legfrissebb lehetôségeket kihasználva, versenyképes piaci szereplóként ôrzi meg hatalmi súlyát. A globális gazdasági versenynek az elvándorlás, a tisztviselók boldogsága, a hivatali hatékonyság is része. Igyekeztünk példákat hozni arra, mely területeken léphet az állam afelé, hogy túlélôje, sôt nyertes résztvevője legyen az új gazdasági-hatalmi rendnek. Ehhez álláspontunk szerint tanácsos a tanulószervezetek eszmeiségének alkalmazása egyre szélesebb körben, a kriptopénzek állami eszközként való felhasználása a közjó érdekében, illetve a részben hasonló elosztott struktúrákon alapuló blockchain-technológia közigazgatásban történô felhasználása, elterjedése mint automatikus igazgatási szint bevezetése.

\section{JEGYZETEK}

1 A tanulmány a KÖFOP-2.1.2-VEKOP-15-201600001 azonosító számú, „A jó kormányzást megalapozó közszolgálat-fejlesztés" elnevezésú kiemelt projekt keretében múködtetett Ludovika Kiemelt Kutatómúhely keretében, a Nemzeti Közszolgálati Egyetem felkérésére készült.

2 Gellén, 2015. Lásd a szakértelem felhasználásával, kamatoztatásával kapcsolatos kérdôíveredményeket, melyre a tanulmány késốbbi részében részletesen utalunk.

3 Gómez Dávila, 2014:31. Elhangzott 2017. október 20-án a PPKE BTK La revanche de Dieu. Felekezet és politikai hatalom a modern korban elnevezésú konferencián Tóth Miklós Vallás, politika és modernitás Nicolas Gómez Dávila gondolkodásában címú elôadásán.

4 Magyarország Alaptörvénye, XXIV. cikk: „Az állam - a múködésének hatékonysága, a közszolgáltatások színvonalának emelése, a közügyek jobb átláthatósága és az esélyegyenlőség előmozdítása érdekében - törekszik az új múszaki megoldásoknak és a tudomány eredményeinek az alkalmazására."

5 http://magyaryprogram.kormany.hu/admin/ download/d/2c/40000/Magyary\%20kozig\%20 fejlesztesi\%20program\%202012\%20A4.pdf.
6 A harmadik a gyártási folyamattal kapcsolatos, témánk szempontjából irreleváns.

7 Malone, 2012; a téma iránt érdeklôdők további forrásokat találhatnak a Society for Organizational Learning honlapján: www.solonline.org Lásd: 2013.01-07. Tanoda kutatás, Roma Education Fund, T-Tudok Tudásmenedzsment és Oktatáskutató Központ Zrt., illetốleg: 2014.05-10: Külhoni Magyar Ifjúságkutatás 2014, Nemzetstratégiai Kutatóintézet. Szarvas, 2014.

8 Contemplative Science and Management, International Transdisciplinary Conference, 19-21 May, 2017, Budapest.

9 Elhangzott a Párbeszéd Házában 2017. március 17-én megrendezett, Azzá válni, aki vagyok címú Mindfulness konferencián.

10 A Christian A. Schwarz német teológus által vezetett kutatás a világ 70000 közösségében nagyon hasonló eredményeket, szemléletet hozott, s a magyarul témában megjelent könyv címe szintén a Magától címet viselve erre az organikus megközelítésmódra utal, amely úgy tûnik, kultúrkörtôl és nemzetiségre való tekintet nélkül világszerte múködni látszik a közösségek szervezôdésének mintázataiban.

11 Lásd még Zoltayné Paprika, 2010.

12 A tanulmányban a helyi önkormányzatoknál való alkalmazási lehetôségekrôl (részvételidemokrácia-fejlesztések, e-demokrácia-szoftverek, politikai kommunikáció; részvételi költségvetés) külön nem térünk ki. Lásd a szerzốk megjelent korábbi tanulmányát, amely kifejezetten az ilyen irányú alkalmazási lehetôségeket veszi górcsố alá: Szarvas-Mezô, 2017.

$13 \mathrm{http}: / /$ bitport.hu/esztorszagbol-country-as-aservice-lesz-gyujtik-a-virtualis-polgarokat.html.

14 https://bitcoin.org/en/developer-guide\#p2 pkh-script-validatio.

15 www.ethnews.com/vitalik-buterin-and-joseph-poon-produce-scalability-solution-the-plasma-framework

16 https://github.com/ethereum/wiki/wiki/ White-Paper.

17 Az empirikus kutatás adatai alapján megállapítható: „....a vezetôk, a minisztériumi dolgozók és a régebb óta a közigazgatásban dolgozók úgy vélik, hogy szakértelmüket jobban ki kellene használni”. Gellén, 2015:110, 31. ábra: A szakértelem hasznosításának vágya.

18 A felvetés Hiroko Kudo 2015-ös elôadásának gondolatmenetébốl indul ki, miszerint pl. az 


\section{Tudományos múhely}

állampolgári részvétel formáit, módjait illetôen jelenleg világszerte az angolszász részvételi koncepció alapján mérik, illetôleg értelmezik az állampolgári aktivitást, amely azonban nem alkalmas teljességében eltérô társadalmi fejlôdésû, kulturális hagyományokkal bíró országok esetén. A helyi kulturális logika megértésének fontosságát hangsúlyozza tehát, s feltételezi, hogy azon struktúrák, melyek hasonló szervezôdési elveket foglalnak magukban, mint az adott ország saját kulturális hagyományai, adekvátabb módon írják le a társadalmi múködést s ezen intézmények, megközelítések hatékonyságát. Az ebbôl a gondolatmenetbôl kiinduló tanulmányt a hazai e-demokrácia-kezdeményezésekrôl lásd Szarvas, 2015.

19 Lásd bôvebben Szarvas, 2015.

20 A társadalomtudományok és informatika terén azokat a hálózatokat hívjuk heterarchiának vagy heterarchikusan szervezôdônek, amelyeknek minden eleme ugyanolyan horizontális pozícióban helyezkedik el egymáshoz képest a hatalmi és irányítási helyzetét tekintve, tehát elméletileg egyenrangú szerepet játszik mindegyik. A heterarchia bizonyos szempontból mutat hasonló vonásokat a hierarchiához, hierarchikus szervezôdéshez, magában foglal hierarchiákat, hierarchikus szervezôdési struktúrát egyaránt, tehát nem teljesen egymást kizáró struktúrákról beszélünk. Tulajdonképpen egy hierarchikus rendszer potenciálisan heterarchikus csoportokat tartalmaz. A heterarchia koncepcióját elôször modern kontextusban Warren McCulloch alkalmazta 1945-ben. Alternatív kognitív struktúrákat vizsgált, s ezek kollektív szervezódését nevezte el heterarchiának. Bebizonyította, hogy az emberi agynak, miközben meglehetôsen jól szabályozott, nem kifejezetten hierarchikus a múködési módja. Ez a felfedezés forradalmasította az agykutatást, és alapvetô fontosságú problémákra adott választ a mesterséges intelligencia és komputer design területén. „Az értékek heterarchiája az idegi hálózatok topológiája által meghatározott" (McCulloch, 1945:89-93). Illetôleg a heterarchia egy olyan szervezôdési mód, amelyben a szervezôdés elemei nincsenek rangsorolva (legalábbis nem hierarchikus módon), illetôleg ahol az egyes elemek rendelkeznek azzal a potenciállal, lehetôséggel, hogy különbözô szempontok alapján egymástól eltérô módon legyenek újrarangsorolva, tehát nem megszilárdult, hanem újrastrukturálható rangsorról beszélünk, van tehát egyfajta rugalmasság a hierarchiában. Crumley, 1995. Idézi Szarvas, 2016b.

${ }^{21}$ https://en.wikipedia.org/wiki/Zero-knowledge_proof.

22 https://e-estonia.com/solutions/security-andsafety/ksi-blockchain/.

23 A NATO beszállítókat keres (2016) innovatív technológiákra, mint pl. a blockchain alkalmazása hadászati logisztikára és beszerzési eljáráshoz. www.ncia.nato.int/NewsRoom/Pages/160425_ Innovation.aspx.

24 www.ibm.com/blogs/blockchain/category/ blockchain-in-food-safety/.

25 www.usedust.com/.

26 Lásd a szerzôk témában megjelent korábbi tanulmányát, Szarvas-Mezô, 2017.

27 Statista, 2016. Global market for blockchain technology 2016-2021. (Reference available upon request due to reference distribution restrictions).

28 www-01.ibm.com/common/ssi/cgi-bin/ssialias?htmlfid=GBE03790USEN\&.

29 www.hashcash.org/papers/hashcash.pdf.

30 https://download.wpsoftware.net/bitcoin/oldpos.pdf.

\section{FELHASZNÁLT IRODALOM}

Bencsik Andrea (2009): A tudásmenedzsment emberi oldala. Z-Press Kiadó, Budapest.

Bohm, David (2011): A dialógusról. Sol Intézet, Budapest.

Crumley, Carole L. (1995): Heterarchy and the Analysis of Complex Societies. Archeological Papers of the American Anthropological Association Vol. 6, No. 1, https://doi.org/10.1525/ ap3a.1995.6.1.1.

Csíkszentmihályi Mihály (2009): Jó üzlet. Vezetés, áramlat és az értelem keresése. Lexecon Kiadó, Gyôr.

Fisher, Roger - Ury, William (1981): Getting to Yes. Penguin, New York.

Gauthier, Alain (2011): Emerging Concepts and Forms of Integral Leadership: Embodying a Radically New Development Paradigm. Integral Leadership Review, Vol. 11, No. 5, http://integralleadershipreview.com/3978-emerging-concepts-and-forms-of-integral-leadership-embodying-a-radically-new-development-paradigm/. 


\section{Tudományos múhely}

Gellén Márton (2015): Közigazgatás: Reform után, átalakitás közben. A 2010-2014-es idôszak közigazgatási reformja az érintettek véleménye alapján. Patrocinium, Budapest.

Gómez Dávila, Nicolás (2014): További széljegyzetek egy rejtett szöveghez. Qadmon Kiadó, Budapest.

Karácsony Sándor (1939): A magyar észjárás. Exodus, Budapest.

Kopp Mária (2008): Magyar lelkiállapot 2008. Semmelweis Kiadó, Budapest.

Laloux, Frederic (2016): A jövố szervezetei. Hogyan hozzunk létre az emberi tudatosság következố szintje által inspirált szervezeteket. Aquilone, Budapest.

Malone, Thomas W. (2012): MIT Conference Focuses on 'Collective Intelligence'. Boston Herald, 3 April.

McCulloch, Warren (1945): A Heterarchy of Values Determined by the Topology of Nervous Nets. Bulletin of Mathematical Biology, Vol. 7, No. 2. Memani, Krishna (2017): How To Invest For The Rest Of 2017. Forbes, jun 19, www.forbes.com/ sites/oppenheimerfunds/2017/06/19/how-toinvest-for-the-rest-of-2017/\#6f4965366d83.

Narayanan, Arvind - Bonneau, Joseph - Felten, Edward - Miller, Andrew - Goldfeder, Steven (2016): Bitcoin and Cryptocurrency Technologies. Princeton University Press, Princeton.

Nemeslaki, András (2016): The Theory of "IT-Government" Alignment: Assessment of Strategic Fit in Hungary"s Case. Central and Eastern European e-Dem and e-Gov Days 2016, Multi-Level (e) Governance - Is ICT a means to enhance transparency and democracy? Conference Proceedings, 85-92.

Ruzsa Ágota - Jobbágy Mária - Szentirmai Judit (2012): Art of Hosting - Dialógusok és Társas teremtés, Sol Füzet, Budapest

Scharmer, Otto (2013): Leading From the Emerging Future. From Ego-system to Eco-system Economies. Berrett-Koehler Publishers, San Francisco.

Senge, Peter M. (1998): Az 5. alapelv. HVG Kiadó, Budapest.

Senge, Peter - Scharmer, Otto - Jaworski, Joseph Flowers, Betty Sue (2004): Presence. Human Purpose and the Field of the Future. Sol, Cambridge.

Szarvas Hajnalka (2014): Külhoni magyar ifjúsági helyzet(ek). In: Székely Levente (szerk): Magyar identitás határon innen és túl. Új Ifjúsági Szemle Alapítvány, 87-135.

Szarvas, Hajnalka (2015): Cultural Embeddedness of e-Participation Methods in Hungary. Proceedings of the 17th International Conference on e-Democracy and e-Participation, Rome, International Scholarly and Scientific Research and Innovation waset.org, International Science Index, World Academy of Science, Engineering and Technology, 566-573.

Szarvas Hajnalka (2016a): A Szent Korona-tan aktualitása. Doktori múhelytanulmányok, Széchenyi István Egyetem, Állam- és Jogtudományi Doktori Iskola, 205-217.

Szarvas, Hajnalka (2016b): Ancient Futures? Decision-Making Softwares Following the Traditional Way of Community Organizing Patterns. Central and Eastern European e-Dem and e-Gov Days 2016, Multi-Level (e) Governance - Is ICT a means to Enhance Transparency and Democracy? Conference Proceedings, 483-499.

Szarvas, Hajnalka - Mezô, Tamás (2017): The Difference of the Impact Between Face to Face Communication Compared to Political Debates in Cyber Space. Central and Eastern European E-Dem and E-Gov Days 2017. Digital Divide in the Danube Region: Is it Still Significant in Explaining ICT Adoption in e-Democracy and eGovernment? Proceedings of the Central and Eastern European e-Dem and e-Gov Days 2017, May 4-5, 2017, Budapest, 97-111.

Valeyre, Antoine - Lorenz, Edward - Cartron, Damien - Csizmadia Péter - Gollac, Michel - Illésy Miklós - Makó Csaba (2009): Munkaszervezeti modellek Európában és az emberierôforrás-gazdálkodás néhány jellemzôje - Kísérlet a munkaszervezetek nemzetközi paradigmatérképének elkészítésére. Vezetéstudomány, 40. évf., 10. sz., $1-15$.

Zlinszky János (1999): A Szentkorona-eszme és története. In: Molnár Tamás et al. (szerk.): A magyar Szent Korona és a Szentkorona-tan az ezredfordulón. Szent István Társulat, Budapest, 7-35.

Zoltayné Paprika Zita (2010): Racionális és intuitív döntéshozók Kaliforniában és Magyarországon, Vezetéstudomány, 41. évf., 6. sz., 24-37. 


\section{Grebelyné Kiss Evelin}

\section{Az abortusz törvényi szabályozása és megítélése napjainkban}

\section{Statutory Regulation and Different Views of Abortion in Today's World}

ÖSSZEFOGLALÁS

Az abortusz napjaink egyik igen vitatott bioetikai problémája. A magzat emberi mivoltát sokan megkérdójelezik, mások viszont egyenesen gyilkosságnak tartják az abortuszt, pedig már az élet definiálása is komoly nehézséget okoz. A törvényi szabályozás lehetôséget ad a nôk kezébe, de vajon beszélhetünk-e az abortuszról az erkölcsi dilemma említése nélkül?

Kulcsszavak: abortusz, magzat, jog, erkölcs

\section{SUMMARY}

Abortion is one of the most controversial bioethical problem today. Many people are questioning the human nature of the fetus, while others see abortion as a murder, but the definition of life also causes serious difficulties. Legislative regulation gives women a possibility, but can we talk about abortion without mentioning the moral dilemma?

Keywords: abortion, fetus, law, morality

\section{TÖRTÉNELMI ÁTTEKINTÉS}

Az ókori görög és római kultúrában elfogadták az abortuszt, azonban orvosok a hippokratészi eskü miatt nem végezhették, így ez a bábák feladata volt. Több száz módszert ismertek, a mechanikai eszközökön túl különbözô fôzzetek és kenốcsök receptjei maradtak fenn, melyeket maga Hippokratész írt, és egyes receptjeiben szereplô növényekrôl a mai napig bizonyított, hogy abortív és fogamzásgátló hatású. „Miután a terhes asszony két napot böjtölt, dagasszál kovásztalan kenyeret közönséges magrugó levével, és ezt helyezze fel. Patkánymagból mintegy kétmaréknyit

Grebelyné Kiss Evelin, MSc, biofizikus, Eötvös Loránd Tudományegyetem, Természettudományi Kar (grebelyne.kiss.evelin@gmail.com). 


\section{Tudományos múhely}

oldjál fel mézes vízben, majd add inni. [...] Tengeri skorpióepét csavarj gyapjúba, és szárítsd meg árnyékos helyen, majd helyezze fel. Közönséges magrugó magvát és égetett kagylóhéjat oldjál fel nyúlszôrt tartalmazó borban, majd gyapjúba téve helyezze fel."1 Az ókori görög jogban a nônek nem volt közjogi státusza, így az önrendelkezés jogilag értelmezhetetlen volt számukra. A házasság célja elsôsorban az utódnemzés volt, mely szintén összeférhetetlen az abortusz jogszerúségével. Lükurgosz és Szolón törvényei hasonló gondolkodáson alapultak: a nôknek sportolni kellett, hogy a magzat egészséges, edzett testben fejlődjék, és a nôk bírják a várandóssággal járó nehézségeket, illetve a szülést (Jobbágyi, 1993b:11). Spártában tiltották az abortuszt a katonai erô utánpótlása miatt, viszont a megszületett, de alkalmatlannak ítélt csecsemóket megölték. Régészeti leletek bizonyítják, hogy az ókori Rómában végeztek abortuszt, bronztûk, horgok és gyúrús kések álltak az orvosok rendelkezésére. Mivel azonban a római jog a fogantatástól számítja a magzat státuszjogát, védelem illette meg. Az abortuszt emberölésként kezelte a római jog, és szankcionálta (Jobbágyi, 1993b:13). Hammurápi törvényei szerint a magzatot vagyontárgyként kezelték: amennyiben nemes vetette el, pénzbírságot kellett fizetnie. Ha szolgáló vagy rabszolganố vetélt el, akkor csak a munkáskezektôl való elesést jelentette az uralkodó számára. „Ha egy awélum (szabad nemes) awélum lányát megütötte, és magzatát elvetéltette vele, 10 siglum ezüstöt fizessen a magzatért" (Harmatta, 1964:153). Mózes második könyvéból kiderül, hogy a zsidó-keresztény vallás alapjául szolgáló Biblia szerint életért élettel kell fizetni. „Ha férfiak veszekednek, és meglöknek vala- mely terhes asszonyt, úgy hogy idô elôtt szül, de [egyéb] veszedelem nem történik: bírságot fizessen... De ha veszedelem történik: akkor életért életet adj" (2Móz 21,22-23).

Gratianus itáliai jogász világosan fogalmaz az abortuszt illetően: „Az anyaméhben megfogamzott magzatot, aki abortusszal elpusztítja, embergyilkos.” Ettôl kezdve az egyházban két, egymásnak ellentmondó irány alakult ki. Az egyik Aquinói Szent Tamás elképzelését követi, mely szerint az abortusz a test és lélek egyesülése elôtt „csak” bûnnek számít, nem pedig gyilkosságnak. Valószínúleg erre az elméletre alapoz számos ország jelenlegi szabályozása, mivel egy bizonyos idôpontig engedélyezik a terhesség megszakítását. A másik irány abból a kérdésbôl indult ki, hogy mi a teendô, ha az anya élete veszélyeztetett. Ebben az esetben az anya életének megmentése elsôbbséget élvez a magzattal szemben (Jobbágyi, 1993b:16). A 13. századtól a kereszténység a magzatot akkor tartotta értelmes lénynek, ha már megmozdult (ettôl kezdve nevezte „átlelkesültnek”). Ez a felfogás évszázadokig kitartott, és csak 1869-ben távolították el a kánonjogból az átlelkesült és át nem lelkesült magzat fogalmát. Ekkortól minden abortusz gyilkosságnak számít a katolikus egyház szerint (Turai, 2012).

\section{A MAGYAR SZABÁLYOZÁS}

Az abortusz tilalma a 20. századra teljesedett ki az állam politikai és katonai megerôsödése okán, így Rákosi idején Magyarországon is. A terhességmegszakítást akár öt év börtönnel is büntethették, ezért az illegális abortuszok száma rettentôen megemelkedett. 1956-tól a 
Ratkó-törvény feloldásával ismét nôni kezdett az abortuszok száma, majd az 1970-es években kezdett csökkenni, amikor a hormonális fogamzásgátlók kezdtek elterjedni. ${ }^{2}$ A rendszerváltozás után az abortusz kérdéseit alkotmányossági szempontból is vizsgálták, az Alkotmánybíróság kétszer is foglalkozott a témával. Elsôként a 64/1991. (XII. 17.) AB határozatban járta körül az abortusz akkori szabályait: a magzat jogalanyisága nem egyértelmú, azaz a magzatot nem illetik meg ugyanazok a jogok, mint egy már megszületett személyt. A magzat élethez való joga nem korlátlan, befolyásolhatja az anya egészséghez és önrendelkezéshez való joga. A 48/1998. (XI. 23.) határozatban döntött az Alkotmánybíróság, kifejezett rendelkezés nincs a törvényben a jogalanyiságra vonatkozóan, tehát a magzat nem jogalany. ${ }^{3}$

A 2012. január 1-jén hatályba lépett új Alaptörvény szerint „a magzat életét a fogantatástól kezdve védelem illeti meg”. ${ }^{4}$ E szerint az állam köteles a magzatot védeni, mint keletkezésben lévô életet. Az abortusz jogi kereteit a magzati élet védelmérôl szóló 1992. évi LXXIX. törvény és annak végrehajtási rendelete, a 32/1992 (XII. 23.) NM rendelet biztosítja. Legálisan az abortusz csak a jogszabályban meghatározott idôkorláton belül végezhetô el, mely a fôszabály szerint maximum a terhesség 12. hetét jelenti az alábbi esetekben:

- Amennyiben az állapotos nô egészségét súlyosan veszélyeztetô ok indokolja. Ebben az esetben két, szakmailag illetékes szakorvos megegyezô véleménye szükséges.

- A magzat orvosilag valószínúsíthetôen súlyos fogyatékosságban vagy egyéb károsodásban szenved. Szintén két szakorvos egybehangzó véleményére van szükség a genetikai tanácsadó, a prenatális diagnosztikai központ, valamint az illetékes országos intézet által kijelölt kórházak szülészeti-noogyógyászati osztályának orvosai közül.

- A terhesség búncselekmény következménye. Ebben az esetben a terhes nónek részt kell vennie egy tanácsadáson, melyen a Családvédelmi Szolgálat munkatársának kell bemutatnia a nyomozó hatóság által kiadott, a búncselekmény megtörténtéról vagy annak alapos gyanújáról szóló igazolást.

- Az állapotos nô súlyos válsághelyzete esetén. A jogszabályi meghatározás szerint súlyos válsághelyzet az, amely testi vagy lelki megrendülést, illetve társadalmi ellehetetlenülést okoz. Írásban kell kérelmezni a súlyos válsághelyzet kinyilvánításával, mely mindössze egy aláírás. A Családvédelmi Szolgálatnál két alkalommal kötelezô tanácsadáson kell részt venni, a két tanácsadás között legalább három nap várakozási idônek kell eltelnie.

A 18. hétig elvégezhetô a terhesség megszakítása, ha a kérelmezô korlátozottan cselekvốképes vagy cselekvôképtelen (pl. kiskorú). Abban az esetben is eddig az idôpontig lehet abortuszt végezni, ha a nô önhibáján kívül, egészségi oknál fogva vagy orvosi tévedés miatt nem észlelte a terhességét, és abban az esetben is, ha a nố az egészségügyi intézmény vagy más hatóság mulasztása miatt lépte túl a 12 hetes idókorlátot. A terhesség a 20. hétig, az eljárás elhúzódása esetén a 24. hétig megszakítható, ha a magzat genetikai vagy teratológiai rendellenességének valószínúsége eléri az 50\%-ot. Bármikor elvégezhetô az abortusz, ha az anya élete van veszélyben, vagy a magzat olyan rendellenessége derül ki, mely a születés utáni élettel összeegyeztethetetlen. ${ }^{5}$ 
A terhesség engedély nélküli megszakítása bûncselekménynek minôsül, melyet a Büntetô törvénykönyv 163. §-a a következôk szerint büntetni rendel:

Aki más magzatát elhajtja, búntettet követ el, és három évig terjedô szabadságvesztéssel büntetendô. A büntetés egy évtôl öt évig terjedô szabadságvesztés, ha a magzatelhajtást

- üzletszerúen,

- a nô beleegyezése nélkül,

- súlyos testi sértést vagy életveszélyt okozva követik el.

A büntetés két évtôl nyolc évig terjedô szabadságvesztés, ha a magzatelhajtás halált okoz. Az a nô, aki magzatát elhajtja vagy elhajtatja, vétséget követ el, és egy évig terjedô szabadságvesztéssel büntetendô. ${ }^{6}$

Magyarországon nincs szükség arra, hogy a várandós megindokolja, miért kívánja elvetetni a magzatot, azonban a két kötelezố tanácsadáson részt kell vennie a Családvédelmi Szolgálatnál, mely legtöbbször a területileg illetékes védônốt jelenti. A két beszélgetés között minimum három napnak el kell telnie, az elsố beszélgetés célja a magzat megtartására irányul (Csarmasz et al., 2016:590-591). A Patent Egyesület 2014-ben végzett kutatása alapján az elsố beszélgetésre 40756 nố ment el, a második alkalmon 37862 nó jelent meg, abortuszt viszont 36118 esetben végeztek. Az ok viszont nem egyértelmú: valóban a védônôk sikere ez a 10\%? Mivel ezeket a beszélgetéseket sok nố komoly lelki teherként, egyesek megaláztatásként élték meg, az sem kizárt, hogy aki megtehette, inkább külföldre ment elvégeztetni a beavatkozást, így ôk a magyarországi számadatokból kiesnek. ${ }^{7}$

Az „abortuszturizmusnak” azonban más oka is van, ez pedig az itthon még nem elérhetô tablettás megoldás (Valkai,
2012). A tablettát már az 5. és 7. hét között lehet használni, és távozik a petezsák, és mivel nincs mútét, a méhûri fertôzések veszélye és az altatással járó komplikációk csökkennek, illetve nố egy késóbbi problémamentes szülés esélye. Hátránya azonban, hogy az erôs vérzés hetekig elhúzódhat, illetve ha a méh nem ürül ki teljesen, ugyanúgy szükség lehet vákuumszívásra vagy kaparásra. Az Országos Gyógyszerészeti és Élelmezés-egészségügyi Intézet 2012 májusában regisztrálta a mifepristone és misoprostol hatóanyag-tartalmú gyógyszerkészítményt, azonban törölték a törzskönyvet, vagyis nem lehet kereskedelmi forgalomban értékesíteni, itthon nem lehet beszerezni. ${ }^{8}$ A misoprostol hatóanyag-tartalmú készítménybốl jelenleg kettô van forgalomban Magyarországon, itthoni indikációjuk kizárólag a vajúdás megindítására vonatkozik, tehát alkalmazásuk a 36. hét elôtt kontraindikált. ${ }^{9} \mathrm{Nem}$ kizárt, hogy ennek ellenére bizonyos esetekben abortusztablettaként is használják, azonban ilyen alkalmazása a hatályban lévô jogszabályok fényében illegális.

Magyarországon az ezredfordulót követô évtizedben a terhességmegszakítások csökkenô tendenciát mutatnak. 2000 és 2011 között több mint egyharmadával, 59,2 ezerrôl 38,4 ezerre esett a múvi vetélések száma, az évenkénti változás dinamikája nem volt egyenletes, de a csökkenés mindenképp figyelemre méltó (KSH, 2012). Az abortuszok száma 2010 és 2015 között 23\%-kal, 2016 elsố negyedévében pedig további 4\%-kal csökkent (Surjányi, 2016).

\section{NEMZETKÖZI KITEKINTÉS}

Az abortusztörvényt a következô három paraméter alapján szokták vizsgálni: hozzáférhetôség, idôtartam és az engedélye- 
zéshez szükséges feltételek. Európában a hozzáférhetôség változó, a teljes tiltástól a kérésre hozzáférhetôségig terjed (Farkas, 2012:21). Magyarország még a liberálisabb országok közé tartozik, Lengyelország és Írország szigorúbb, azonban Ausztriában, Finnországban, Norvégiában és Spanyolországban nincs háromnapos kötelezô várakozási idô a mútét elốtti két kötelezó tanácsadás között. Csehországban az abortusz a terhesség 12. hetéig végezhetô legálisan, de 1993 óta a társadalombiztosítás csak az egészségügyi okok miatt végrehajtott terhességmegszakítást fedezi. Franciaországban 1975 óta a terhesség megszakítása csak a 10. hétig engedélyezhetố, valamint további feltételek a tanácsadáson való részvétel és az egyhetes várakozási idô. A 10. hét után akkor végezhetô el az abortusz, ha a magzat súlyos testi fogyatékosságban szenved, vagy a nố egészségét veszélyezteti a terhesség, ehhez két szakorvos véleménye szükséges. Németországban egy 1995-ben alkotott törvény a fogamzás pillanatától védelemben részesíti a magzatot, emiatt ebben az országban is kötelezó a terhes nônek tanácsadáson részt vennie, melynek célja a magzat megtartására irányul. Az egészségügyi biztosítás csak alacsony jövedelem igazolása esetén fedezi az abortuszt. ${ }^{10}$

Olaszországban a terhesség elsô 90 napjában lehetséges annak megszakítása. Hollandiában a jogszabály szerint az abortusz a fogamzás és az életképesség közötti idôszakban lehetséges, tehát nincsen konkrétan meghatározott ideje. Az életképesség elérését a 24. hét körüli idôre teszik, ugyanakkor a 22. hét után csak ritkán végeznek abortuszt. A beavatkozás elvégzését mindig megelôzi egy ötnapos várakozási idô, ha a terhes nố esetleg meggondolná magát. ${ }^{11}$
Európa egyik legszigorúbb országa az abortuszt illetôen Lengyelország. 1993ban született meg az a törvény, amely három esetben legitimálja a terhességmegszakítást: ${ }^{12}$

1. orvosi jóváhagyással a nố egészségének veszélyeztetése vagy a magzat súlyos testi fogyatékossága esetén;

2. ha a terhesség búncselekmény eredménye (pl. nemi erôszak), amit az ügyésznek meg kell erôsítenie;

3. szülôi hozzájárulással kiskorú esetében.

A lengyel jog szerint búncselekménynek minôsül, ha valaki a terhesség megszakítására akarja rávenni a nốt, azonban nem bünteti a nốt, ha illegális abortuszt végeztet.

Svédországban a 18. hétig lehet a törvény szerint megszakítani a terhességet, eddig az idôpontig bármilyen okból el lehet végezni. A 18. és a 22. hét között orvosi hozzájárulás szükséges, és csak egészségügyi ok miatt kérvényezhetô az abortusz elvégzése. Ausztriában a kérelmezett abortusz akkor legális, ha az a nô életét, fizikai vagy lelki egészségét védi, vagy ha a magzat valószínúsíthetôen súlyos fejlôdési rendellenességgel születne meg. A megszakításnak az elsố három hónapban kell megtörténnie. Bulgáriában, Dániában, Portugáliában és Szlovákiában megengedett az abortusz, ha a terhesség elsố harmadában kérvényezik. Indok lehet a terhes nô gazdasági-társadalmi helyzete, vagy ha a magzat valószínúleg fejlódési rendellenességben szenved, illetve ha a terhesség nemi erôszak eredménye. Romániában az abortusz a terhesség 14. hetéig törvényes. Belgiumban az abortusz kérelemre legális. Észtországban, Görögországban, Lettországban, Litvániában, Szlovéniában szintén engedélyezett. Cipruson, Luxem- 
burgban és Spanyolországban úgy nem kerülhet sor abortuszra, hogy a nô kérelmezi, de elvégezhetố a beavatkozás, ha az a nô egészségének megóvása érdekében történik, vagy ha a magzatnak valószínúsíthetôen valamilyen rendellenessége van, illetve abban az esetben is, ha a terhesség nemi erôszak következménye, vagy ha a nố hátrányos társadalmi és/vagy gazdasági helyzetben él. Máltán minden esetben illegális a terhesség megszakítása, még akkor is, ha ez a nô életét veszélyezteti. ${ }^{13}$

A tengerentúlon, például Kanadában 1988-ban eltörölték az abortusztörvényt a nốk jogaira hivatkozva, a nem kívánt terhesség megszakítását gyógyszeres kezelésnek minôsítették (Új Ember, 2018). Kanadával együtt összesen hét országban engedélyezik az abortuszt a terhesség késôi szakaszában: Észak-Korea, Kína, Hollandia, Szingapúr, Vietnám és az Egyesült Államok (Ráti, 2018).

$\mathrm{Az}$ angolszász területeken nincs egységes szabályozás. Angliában, Skóciában és Walesben a terhesség a 28. hétig megszakítható, ha az anya életét, testi és lelki egészségét veszélyezteti, illetve ha a magzat valószínúsíthetôen súlyos fogyatékossággal születne. Írországban viszont az abortusz csak akkor engedélyezhetô, ha a terhesség a nô életét veszélyezteti. Az abortusztilalom feloldásáról népszavazást tartottak 2018 májusában, ahol a többség a tilalom eltörlésére szavazott, mely eredmény gyökeresen megváltoztathatja az ír nôk életét (Hvg.hu, 2018).

Az Egyesült Államok összes tagállamában 1967-ig védelemben részesítették a magzat életét, egyetlen kivétellel: ha az anya életét veszélyezteti (Grmela, 1992:681). A Legfelsôbb Bíróság döntésével irányt mutatott a tagállamoknak, a terhességet három 12 hetes trimeszterre osztotta. Az elsố trimeszterben az államok nem szabályozhatják az abortuszt azon túl, hogy a beavatkozást engedélylyel rendelkezố orvosnak kell végeznie biztonságos egészségügyi intézményben. A második trimeszter alatt az állam úgy szabályozhatja a terhesség megszakítását, amely elôírás észszerúen kapcsolódik a nố egészségéhez. A harmadik trimeszterben az állam érdeke, hogy óvja a magzatot mint potenciális életet, és ez megelôzi az anya magánélethez való jogát. Ennek oka, hogy a magzat a terhesség 23. hetéig nem tekinthetô életképesnek, emiatt nem tulajdoníthatnak neki anyától független jogokat. Tehát az állam csak a harmadik trimeszterben tilthatja meg az abortusz elvégzését, kivéve, ha az a nố egészségének megóvása céljából történik. ${ }^{14}$ A Legfelsôbb Bíróság az emberi méltóság alapjának a méhen kívüli önálló életre való képességet jelölte meg, viszont az orvostudomány fejlódésével ez a határvonal egyre korábbra tehetô (Jobbágyi, 1993a:104).

\section{ERKÖLCSI DILEMMA}

Az abortusz kapcsán felmerüló erkölcsi dilemmát nem lehet figyelmen kívül hagyni, függetlenül a törvényben megfogalmazott lehetôségektôl. Az orvosok nem kötelezhetốek a terhességmegszakítás elvégzésére vallás- és lelkiismereti szabadság alapon, kivéve akkor, ha a terhes nô életveszélyben van. Ezzel együtt minden olyan egészségügyi intézményben, ahol van szülész-nôgyógyászat, biztosítani kell legalább egy szakorvost, aki a beavatkozást elvégzi. ${ }^{15}$

A konzervatív csoport megítélése szerint a már megtermékenyített petesejt „potenciálisan egy erkölcsi személy, egy 


\section{Tudományos múhely}

gondolkodó ember” (Kovács, 2006:307). Tehát mint potenciális létezôt veszik alapul, akiben benne rejlik az emberré válás lehetôsége, ezzel kifejezve, hogy az emberi élet morális státusza a megtermékenyítés pillanatától számítható. Eszerint ugyanazok a jogok illetik meg a magzatot, mint egy már megszületett személyt. A liberális nézôpont ezzel szembemegy, az anya önrendelkezési jogát részesíti elônyben. A mérsékelt álláspont képviselôi valahol e két nézôpont között helyezkednek el: a magzat élethez való joga ${ }^{16}$ és a nő önrendelkezési joga egyaránt fontos. Emiatt az abortuszt a magzat egy bizonyos fejlettségi szintjének eléréséig elfogadja (Gradvohl, 2015).

A katolikus egyház egyértelmúen állást foglal az abortusz ellen: „súlyos bû́n, mivel egy ártatlan életnek vet véget” (MNO, 2016). 2016-ban Ferenc pápa azonban minden római katolikus papra kiterjesztette a terhességmegszakításon átesett nôk feloldozásának jogát, amely korábban csak a püspökök és a különleges gyóntatópapok kiváltsága volt (HVG, 2016). Magyarországon elôször az 1990-es években került sor közvélemény-kutatásra az abortusszal kapcsolatban. A kutatásból kiderült, hogy az emberek többsége az életet a fogantatás pillanatától számítja. A terhességmegszakítások nagy része a szociális helyzetre való hivatkozás indokával történt, de ezt a megkérdezettek nem fogadták el megfelelô magyarázatként. Más okokkal, mint például az orvosi, genetikai vagy életkori indokokkal elfogadóbbnak bizonyultak (Jobbágyi, 1992:292-293).

Az abortusz megítélése megosztja a társadalmat és az orvosokat egyaránt, ugyan senki nem örül neki, szükséges rosszként sokan elfogadják. A kérdést tárgyalva nem egyszerú állást foglalni, és ez nem is célom. Ugyanakkor úgy gondolom, hogy ha a törvényi szabályozás megengedi az abortusz elvégzését, azt a lehetô legkevésbé megterhelôvé kellene tenni - fizikailag és lelkileg egyaránt.

\section{JEGYZETEK}

1 http://nsppress.hu/az-abortusz-tortenete-i/.

2 http://nsppress.hu/az-abortusz-tortenete-iii/.

3 https://tasz.hu/betegjog/terhesseg-megszakitas-hazai-szabalyozasa-0.

4 Magyarország Alaptörvénye, II. cikk, http:// net.jogtar.hu/jr/gen/hjegy_doc.cgi?docid= A1100425.ATV.

5 http://abortusz.info/jogi-szabalyozas-gyakorlat.

6 2012. évi C. törvény a Büntetô törvénykönyvrôl 163. § Magzatelhajtás, https://net.jogtar.hu/ jogszabaly?docid=A1200100.TV\&pagenum=2 .

7 http://abortusz.info/kutatas/2014.

8 www.ogyei.gov.hu/gyogyszeradatbazis/index.php?action=show_details\&item $=34184$ (2018.03.08.)

9 www.ogyei.gov.hu/gyogyszeradatbazis/index. php?action=show_details\&item $=162746$, www. ogyei.gov.hu/gyogyszeradatbazis/index.php?action=show_details\&item $=84268$.

10 https://tasz.hu/betegjog/az-abortusz-kulfoldi-szabalyozasa.

11 https://tasz.hu/betegjog/az-abortusz-kulfoldi-szabalyozasa.

12 https://tasz.hu/betegjog/az-abortusz-kulfoldi-szabalyozasa.

13 https://tasz.hu/betegjog/az-abortusz-kulfoldi-szabalyozasa.

14 http://family.findlaw.com/reproductive-rights/ abortion-and-the-law-background.html.

15 http://abortusz.info/jogi-szabalyozas-gyakorlat.

$16 \mathrm{Az}$ élethez való jog más aspektusairól lásd Bányai-Verzár, 2017; Bódi, 2008a; 2008b.

\section{FELHASZNÁLT IRODALOM}

Bányai Dávid - Verzár Zsófia (2017): Gondolatok az eutanázia hazai szabályozásáról és gyakorlatáról. Belügyi Szemle, 65. évf., 9. sz., 63-71.

Bódi Stefánia (2008a): A halálbüntetés nemzetközi története és megítélése - érvek és ellenérvek. Hadtudomány, 18. évf., 3-4. sz., 127-139. 


\section{Tudományos múhely}

Bódi Stefánia (2008b): A halálbüntetés hazai szabályozásának története, különös tekintettel a katonai bûncselekményekre. Hadtudományi Szemle, 1. évf., 2. sz., 47-53.

Csarmasz Eszter - Tóth Kata Otília - Tóth Rebeka Bernadett (2016): A várandósság megszakítása [abortusz]. Élet és Tudomány, 71. évf., 19. sz., 590-591.

Farkas Zita (2012): Az abortusz szigorítása, mint nemzeti „emancipáció”. Társadalmi Nemek Tudománya, 2. évf., 2. sz., 113-131.

Gradvohl Edina (2015): Az abortusz megítélése az antik világban. Kaleidoscope, 6. évf., 11. sz., $1-11$.

Grmela Zoltán (1992): Az abortuszkérdés szabályozása az Egyesült Államokban. Magyar Jog, 39. évf., 11. sz., 681-689.

Harmatta János (1964): Ókori keleti történeti chrestomathia. Tankönyvkiadó Vállalat, Budapest.

HVG (2016): Meggyónható az abortusz. Megbocsátó egyház. $H V G$, 38. évf., 48. sz.

HVG.hu (2018): Írország - újabb zöld jelzés az abortusz-népszavazásnak. $H V G . h u$, http://hvg.hu/ vilag/20180309_Irorszag_ujabb_zold_jelzes_ az_abortusznepszavazasnak (Letöltés: 2018. március 12.).

Jobbágyi Gábor (1992): A méhmagzat életjogának társadalmi összefüggései. Magyar Jog, 39. évf., 5. sz., 289-294.

Jobbágyi Gábor (1993a): A méhmagzat életjoga és az abortuszkérdés az USA és Anglia jogalkotásában és bírói gyakorlatában. Jogtudományi Közlöny, 48. évf., 3. sz., 100-109.

Jobbágyi Gábor (1993b): A méhmagzat jogi helyzete és védelme. A terhességmegszakítás ellen az ókori és középkori jogokban. Magyar Jog, 40. évf., 1. sz., 9-17.

Kovács József (2006): A modern orvosi etika alapjai. Bevezetés a bioetikába. Medicina Kiadó, Budapest.

KSH (2012): Terhességmegszakítások demográfiai jellemzői. Statisztikai Tükör, 6. évf., 110. sz. https://www.ksh.hu/docs/hun/xftp/stattukor/ terhessegmegsz11.pdf (2018.03.12.)

MNO (2016): A pápa kiterjesztette az abortusz megbocsátásának jogát. Magyar Nemzet online, november 21., https://mno.hu/kulfold/ ferenc-papa-kiterjesztette-az-abortusz-megbocsatasanak-jogat-1372518 (Letöltés: 2018. március 12.).

Ráti József (2018): Donald Trump támogatja az abortuszellenes felvonulókat. Index, január 20., https://index.hu/kulfold/2018/01/20/ donald_trump_abortusz_usa/ (Letöltés: 2018. március 11.).

Surjányi Dávid (2016): Végre lassabban fogy a magyar! Hetek, 20. évf., 48. sz., www.hetek.hu/belfold/201612/vegre_lassabban_fogy_a_magyar.

Turai Julianna (2012): Az abortusz történelmi gyökerei. Hetek, 16. évf., 41. sz., www.hetek.hu/ hit_es_ertekek/201210/az_abortusz_tortenelmi_gyokerei.

Új Ember (2018): Abortusztörvény készül Kanadában. Új Ember, február 11., https://ujember. hu/abortusztorveny-keszul-kanadaban (Letöltés: 2018. március 11.).

Valkai Nikoletta (2012): Bécsbe mennek abortuszra a magyar nôk. Index, október 26., https://index.hu/belfold/2012/10/26/abortuszturizmus/ (Letöltés: 2018. március 11.). 


\section{Magyarország válaszlépései a pénzmosással és terrorizmusfinanszírozással kapcsolatos kihívásokra}

\section{Hungary's Responses to the Challenges Related to Money Laundering and Financing Terrorism}

Összefoglalás

A pénzmosással és terrorizmusfinanszírozással összefüggó kockázatok azonosítása minden állam jól megfogalmazható érdeke. A kockázatok csökkentéséhez több esetben határokon átnyúló intézkedésekre és nemzetközi szervezetekre van szükség ahhoz, hogy az államok a búnszervezetekkel és terrorista szervezetekkel szemben felvegyék a küzdelmet.

Journal of Economic Literature (JEL) kódok: D02, D73, F33, G28

Kulcsszavak: pénzmosás, terrorizmusfinanszírozás, Európa Tanács, Magyarország

\section{SUMMARY}

Identifying the potential risks in connection with money laundering and the financing of terrorism is in the best interest of every state. In order to reduce these risks, states and international organizations need trans-border cooperation to fight criminal organizations and terrorist groups.

Journal of Economic Literature (JEL) codes: D02, D73, F33, G28

Keywords: money laundering, financing of terrorism, Council of Europe, Hungary

Tóth Zoltán Balázs, PhD-hallgató, Nemzeti Közszolgálati Egyetem, alapító, Politikai Spektrum Alapítvány (toth.zoltanbalazs@gmail.com). 
A pénzmosással és terrorizmusfinanszírozással összefüggó búncselekmények feltárása minden állam jól körülhatárolható érdeke. Ezen búnelkövetési formák túllépnek a gazdasági bûncselekmények körén, és egyaránt kihatnak az állam nemzetbiztonsági, gazdasági és politikai biztonságára.

A pénzmosás mint tevékenység a búncselekmények elkövetésébôl származó pénz bankrendszerbe történó becsatornázását jelenti, azaz a rejtett gazdaságból származó bevételek „tisztára mosását” (Lentner-Zéman, 2017:19-21). A terrorizmusfinanszírozás ezzel ellentétben kivon a bankrendszerból bizonyos menynyiségú pénzt, hogy azt fedôszervezeteken keresztül vagy közvetlenül eljuttassa a címzettekhez.

Jóllehet a pénzmosással és terrorizmusfinanszírozással összefüggó tevékenységeket eltérô érdekek mozgatják, mégis szoros a kapcsolódás a két jelenség között. Egyfelôl a pénzügyi rendszer szabályozását úgy kell kialakítani, hogy az felismerje a kockázatos pénzmozgásokat - például nagy összegú készpénz letétbe helyezése, illetve felvétele -, amelyet folyamatos monitoringtevékenység támogat. Másfelốl a pénzmosás és terrorizmusfinanszírozás között - elsôsorban a fejlődô országokban - összefonódás figyelhetố meg, amely kapcsán a két búnelkövetési forma szigorú szétválasztása nem lenne szerencsés.

Jelen tanulmány arra fókuszál, hogy feltárja a pénzmosással és terrorizmusfinanszírozással összefüggó kockázatokat Magyarország esetében. Az elsô fejezet áttekinti az elmúlt években végbemenó fóbb jogi és pénzügyi változásokat, egyben nemzetközi kitekintéssel sorra veszi az országot fenyegetố kockázatokat. A második fejezet az Európa Tanács szak- bizottságának vizsgálatára fókuszál, amely a pénzmosással és terrorizmusfinanszírozással kapcsolatos kockázatokat azonosította. A vizsgálat nyomán több ajánlást is megfogalmazott a magyar jogrendszer fejlesztésére, amely kapcsán számos változás látott napvilágot. A harmadik fejezet ezen változásokat veszi sorra.

\section{A magyar állam pénzmosással ÉS TERRORIZMUSFINANSZÍrOZÁsSAL ÖSSZEFÜGGỐ KOCKÁZATAI}

A 2010-es és 2014-es országgyúlési választásokon kormányra jutó pártszövetség alapjaiban átformálta Magyarország közjogi, közpénzügyi rendszerét. A közjogi rendszer tekintetében mérföldkônek számított az új Alaptörvény 2012. január 1-jén történố hatálybalépése. Az 1990-es rendszerváltást követôen ugyan voltak kísérletek egy új alkotmány elfogadására, mégis több mint két évtizedet kellett várni ahhoz, hogy a nemzetközi standardokhoz és a modern kor elvárásaihoz illeszkedô okmány szülessen. Az Alaptörvénnyel kéz a kézben számos egyéb kiemelt jelentôségú jogszabály született vagy módosult - kiemelendố például a Büntetố törvénykönyv és a Polgári törvénykönyv.

Az Alaptörvény tekintetében érdemes aláhúzni, hogy szigorú kereteket állít fel az éves költségvetés elfogadása és az államadósság elleni harc szempontjából, valamint kiemelt szereplóként kezeli a Magyar Nemzeti Bankot, az Állami Számvevőszéket, illetve a Költségvetési Tanácsot. Minderre azért van szükség, mivel az egyik legfő́bb makrogazdasági adatnak számító államadósság és államháztartási hiány túlságosan magas mértéke megrengetheti az országba vetett bizalmat, ami spirálként gyúrúzik tovább az állam múködésére, a 
közszolgáltatások és közjavak minôségére, illetve az állami kötelezettségvállalások teljesítésére (Lentner, 2017:14).

A közpénzügyi rendszer tekintetében a kormányzó pártszövetség nyíltan megkérdôjelezte a neoliberális paradigma létjogosultságát, mivel a 2008-as gazdasági válság rámutatott arra, hogy az addig regnáló rend nem képes biztosítani a kulcsfontosságú pénzügyi piacok és a pénzügyi intézményrendszer stabilitását. ${ }^{1}$ A neoweberiánus alapokról újradefiniált magyar állam a nemzetgazdaságban betöltött szerepét is megváltoztatta.

A neoliberális gyökerektôl történô távolodás nem egyedi, hiszen a 2008-as gazdasági világválság nyomán látható volt akár az Egyesült Államok, akár az Európai Unió válságkezelési mechanizmusai kapcsán, hogy csak az aktívabb állami beavatkozás jelenthet megoldást a nemzetgazdasági és társadalmi problémákra egyaránt. A piac mint önszabályozó, önkorrekcióra képes intézmény ideáljának elutasításával párhuzamosan, Magyarországon olyan intézkedések láttak napvilágot, mint a közteherviselés kiterjesztése, a Magyar Nemzeti Bank múködésének átalakítása, ${ }^{2}$ a nemzetgazdaság reorganizációja és revitalizációja, illetve az ezekkel összefüggó társadalmi folyamatokba történô közvetlen beavatkozás.

A fentiekkel összhangban kezdődött el a munkanélküliségi ráta állami beavatkozással történố csökkentése - közfoglalkoztatási program -, a nemzetgazdaság legfontosabb pillérét jelentố kis- és középvállalkozói szektor bürokratikus és pénzügyi terheinek csökkentése, amely alapvetôen igazodik a 2014-2020-as uniós programozási szakaszban lefektetett gazdaságfejlesztési irányhoz (Kondor, 2017:72).
A megváltozott jogi és közpénzügyi gondolkodás nyomában járó változások lehetôséget teremtettek arra, hogy a pénzmosással és terrorizmusfinanszírozással összefüggó szabályozások is változzanak, illetve lekövessék a nemzetközi trendet. Ennek Magyarország szempontjából is stratégiai fontosságú jelentôsége van.

1. Magyarország földrajzi helyzetébôl adódóan több, nem uniós országgal is határos. A polgárháborúval sújtott Ukrajna egyidejúleg több kockázatot is hordoz a vele szomszédos országok szempontjából, ezek közül kiemelendố a szervezett búnözés. A World Economic Forum 137 országot tartalmazó listáján (WEF Organised Crime Index) Ukrajna a 113. helyet foglalja el, Olaszországot leszámítva ennél csak törékeny fejlődố országok kaptak rosszabb besorolást. ${ }^{3}$ A szintén szomszédos Szerbia ugyanezen a rangsorban a 107. helyre fért fel, ennélfogva két szomszédos állam felôl érkezô fenyegetésekkel kell szembenézni.

2. Hasonlóképpen a földrajzi elhelyezkedésból fakadóan, Magyarország egyes bûnelkövetési módok esetében tranzités célország is egyben. Tranzitjellegébốl adódóan így is folyamatosan küzd az Ázsiából és Törökországon keresztül érkezó drogcsempészéssel, és ugyancsak tranzit-, illetve származási ország az emberkereskedelem tekintetében (Drog Fókuszpont, 2017:126).

3. Az arab tavasz nyomán az Európai Unió észak-afrikai és közel-keleti „védôgyúrúje” megbomlott, a polgárháborúval sújtott, illetve a sok esetben egyre rosszabb kilátásokkal bíró országok irányából megindult a tömeges migráció. A 2015/2016-os migrációs válság következtében Magyarország közjogi rendsze- 
re részelemeiben átalakult. Az Alaptörvény 2016-ban beemelte a különleges jogrendek közé a terrorveszélyhelyzet kategóriáját, kiépült a jogi és fizikai határzár, valamint megkezdődött a központi közigazgatási intézmények védelmi felkészítése (Tóth, 2016:100-114). Továbbá a szíriai, iraki és jemeni polgárháborúval párhuzamosan, a Közel-Kelet Irán és Szaúd-Arábia hadszínterévé alakult át, amely küzdelmet a NATO-tagállam Törökország geopolitikai érdekei és beavatkozásai is árnyalnak.

4. Az elôzó ponttal összefüggésben érdemes megjegyezni, hogy az Európai Unió közvetlen geopolitikai környezetén túl számos fejlódô ország hordoz kockázatokat. A törékeny államok politikai vezetése több esetben összefüggésbe hozható bû́nszervezetekkel, illetve terrorista szervezetekkel, míg utóbbiak védelmet élveznek, addig a politikai elit újabb fegyveres erôkkel biztosítja be magát. Ezen országok esetében a pénzmosás és terrorizmusfinanszírozás szintet lép, amely gyakorlatot csak nemzetközi szervezetek lehetnek képesek mérsékelni.

5. Fejlett és fejlődô országoknak egyaránt meg kell küzdeniük olyan globális szinten értelmezhetố kockázatokkal, mint az éghajlatváltozás, a határokon átívelố fegyverkereskedelem vagy a jelen tanulmány szempontjából releváns terrorizmus. A terrorizmust mint jelenséget egyfelól nemzetbiztonsági, másfelôl gazdasági oldalról szükséges kezelni, jelen tanulmány elsôsorban az utóbbira koncentrál. Jóllehet a radikális és terrorista szervezetek „múveleti költségei” számottevốen alacsonyabbak az okozott károkhoz képest, mégis minden múvelethez szükség van anyagi erôforrásokra, illetve gondoskodni kell a szervezet mú- ködésérôl (Gál, 2016:84-85). Ezen szervezetek különbözó forrásokból tehetnek szert bevételekre, adományozás - mely elsôsorban készpénzben történik -, a kereskedelmi bankrendszeren keresztül történố tranzakciók, karitatív szervezetek és vállalkozások múködtetése révén stb. Az államoknak ennélfogva több nemzetgazdasági szereplôt is folyamatos monitoring alá kell vonni, illetve olyan eljárásokat szükséges kidolgozni, amelyek automatikusan jelzik a kockázatokat (például kereskedelmi bankoknál készpénzbefizetés vagy nagyobb összegú átutalás).

6. A fenti kockázatokat csökkenti a gazdasági szereplôk tevékenységének, valamint a pénzügyi rendszer átláthatóságának növelése. Magyarország tekintetében egyfelól ez azért is lényeges, mivel a gazdaságban számottevố mennyiségú készpénz kering, amelynek nyomon követése körülményesebb a bankoknál kezelt számlapénznél. ${ }^{4}$ Másfelól a magyar pénzügyi szektor legnagyobb szegmensét a bankszektor képezi, és átlagosan az ügyfelek 1-3\%-a számít magas kockázatúnak (offshore cégek, külföldi ügyfelek stb.) (Moneyval, 2016:10).

A pénzügyi rendszer szabályozásánál észlelt hiányosságok olyan búnelkövetési módoknak ágyazhatnak meg, mint a pénzmosás, bûnszervezetek ingatlanvásárlásai, embercsempészet, drogkereskedés, korrupció és a terrorista szervezetek finanszírozása. A jogi és pénzügyi kiskapukat kihasználó személyek és szervezetek árnyékgazdasága veszélyt jelent a nemzetgazdaság egészére, ráadásul további szereplôket ösztönözhet arra, hogy az adott országon keresztül bonyolítsák illegális ügyleteiket.

A fentiek alapján látható, hogy a pénzmosással és terrorizmusfinanszírozással 
összefüggó kockázatok feltárására egyidejúleg jelentkezik az adott ország politikai, gazdasági és nemzetbiztonsági adottságaiból, illetve nemzetközi szintrôl érkezô nyomásból. A jogrendszer folyamatos és átfogó fejlesztése - mint ahogy az a 2010 és 2018 közötti időszakban megtörtént - csökkentheti a kockázatok számát, és megfelelô gyakorlatokkal azok még idôben feltérképezhetôvé válnak.

A továbbiakban két olyan nemzetközi szervezet vizsgálatát mutatjuk be, amely kifejezetten a pénzmosással és terrorizmusfinanszírozással kapcsolatos kockázatok feltárását és csökkentését célozza elô. Az Európa Tanács szakbizottsága, illetve a Pénzügyi Munkacsoport (Financial Action Task Force, FATF) célja olyan nemzetközi standardok ajánlása, amely nyomán az országok hatékonyan felléphetnek a szervezett búnözés, illetve a terrorizmus gazdasági csatornái ellen. A fenti két nemzetközi szervezet vizsgálata ráhatással van a jogrendszer alakulására, amely Magyarország esetében a 2010-tôl folyamatosan fejlôdô szabályozási környezet még átfogóbb újragondolását jelenti.

\section{MagyarorsZÁG A NEMZETKÖZI \\ SZERVEZETEK GÓRCSÖVE ALATT}

Az Európa Tanács Pénzmosás és Terrorizmusfinanszírozás Elleni Szakértői Bizottsága (Moneyval) rendszeresen vizsgálja a tagállamok pénzmosás és terrorizmusfinanszírozás visszaszorítását és feltárását célzó szabályozási környezetet. ${ }^{5}$ Ezen vizsgálatokat az OECD mellett múködô FATF ajánlásai és metodológiája alapján folytatja le.

A Moneyval ötödik körös vizsgálatát 2015-2016-ban végezte Magyarországon, szorosan együttmúködve a közpon- ti közigazgatási intézményekkel. A negyedik körös vizsgálathoz képest, amely 2010 januárjában zajlott, Magyarország sikerrel fejlesztette a pénzmosással és terrorizmusfinanszírozással összefüggó szabályozási környezetet, mégis, az azóta végbemenó jogszabályi változások kapcsán még mindig akadtak hiányosságok. A Moneyval vizsgálat eredményeit az úgynevezett országjelentésben publikálták 2016 szeptemberében. Az országjelentésben megfogalmazott minôsítés alapján Magyarország megerôsített nyomonkövetési eljárás alá került, amely következtében a kormányzat a 2017. decemberi plenáris ülésen volt köteles beszámolni az ajánlások átültetésérôl. Az országjelentésben megfogalmazott számos ajánlás fơbb pontjai a következók:

1. A pénzmosás és terrorizmus finanszírozásával kapcsolatos kockázatok elemzése szükséges, amely révén a Magyarországot érintô fenyegetések, valamint a hazai és külföldi vagyongeneráló búncselekmények felismerhetôvé válnak. Míg a hatóságoknak akcióterv kidolgozása, addig a magánszektor képviselóinek kockázatértékelések elkészítése ajánlott. További intézkedések megtétele javasolt a készpénzben történô, nagy összegú kifizetések esetében.

2. A Magyar Nemzeti Banknak intézkedéseket kell tenni a szektorspecifikus kockázatok (bank, biztosító, befektetési szolgáltató) értékelése érdekében, hogy a pénzügyi szektorra vonatkozóan átfogó képpel rendelkezzen. Az MNB-nek és a nem pénzügyi szolgáltatók felügyeleti szerveinek olyan eljárásokat szükséges kialakítani, amelyek figyelembe veszik a pénzmosással és terrorizmus finanszírozásával kapcsolatos rendszerszintú kockázatokat. Az MNB felügyeleti tevékeny- 
ségének erôsítése szükséges továbbá a pénzváltóként múködô ügynökök, valamint az offshore társaságok és hazai gazdasági társaságok pénzügyi intézményekkel való kapcsolatai tekintetében.

3. A pénzügyi és nem pénzügyi szolgáltatók - ügyvédek, közjegyzók és készpénztranzakciókkal foglalkozó kaszinók - esetében szükséges olyan eljárások alkalmazása, amely jogi személyeknél és egyéb szereplőknél a tényleges tulajdonos azonosítására alkalmas, amelyekkel megakadályozhatóak a strómanok és fiktív cégek alkalmazásával elkövetett visszaélések. Az ügyfél-átvilágításon túl ajánlott az ügyfelekkel személyes kapcsolatban álló alkalmazottak átvilágítása is, kifejezetten magas kockázatú ügyfelek és üzleti kapcsolatok esetén.

4. A hatóságok számára biztosítani kell a naprakész céginformációs adatokat, valamint a tényleges tulajdonosi információkat. A cél az, hogy magas kockázatú személyek és társaságok ne kerülhessék el a hatóságok figyelmét azzal, hogy strómanokat bíznak meg a vállalatalapítás és -vezetés ügyeivel. Fontos továbbá, hogy a tulajdonosi körben történô változást azonnal jelezni kell a cégbíróság felé.

5. Fejleszteni szükséges a bưnüldözôi szervek és az ügyészség nyomozási, vizsgálati stratégiáját és módszereit, egyben kidolgozni egy olyan egységes statisztikai nyilvántartást, amely objektív mérôszámokkal támasztja alá a pénzmosással és terrorizmus finanszírozásával kapcsolatos intézkedéseket.

6. Pontosítani szükséges a terrorizmusfinanszírozás és a külföldi terrorista harcosok fogalmait, illetve fejleszteni szükséges ezen szervezetek és személyek irányában fennálló finanszírozási csatornák feltárási módszereit.
7. El kell végezni a nonprofit szféra felülvizsgálatát annak érdekében, hogy a hatóságok valós képet szerezzenek a fenyegetésekrôl és kockázatokról. A nonprofit szféra múködésének átláthatósága és a folyamatos monitoringtevékenység hozzájárul a szervezetek által kezelt vagyon feletti folyamatos ellenôrzéshez. ${ }^{6}$

8. A tömegpusztító fegyverek, valamint a kettôs felhasználású termékek előállításának és kereskedelmének megakadályozása folyamatos és szigorú felügyeletet igényel az államok, akár a nemzetközi szervezetek oldaláról. A jelenlegi szabályozási környezetet az állam alatti szereplôk térnyerése okán szükséges fejleszteni.

A Moneyval országjelentését alapul véve A pénzmosás és a terrorizmusfinanszírozás elleni nemzeti kockázatértékelésrôl szóló intézkedési tervrôl szóló 1333/2017. (VI. 9.) Korm. határozat rendelte el a pénzügyi rendszer pénzmosással és terrorizmusfinanszírozással kapcsolatos részleges felülvizsgálatát és átalakítását. A kormányhatározat több minisztérium mellett a Magyar Nemzeti Bankot, a nyomozó hatóságokat, a vámhatóságot, nemzetbiztonsági szolgálatokat, a rendôrségrôl szóló törvényben meghatározott, a belsố bûnmegelôzési és búnfelderítési feladatokat ellátó szervet, valamint a terrorizmust elhárító szervet és igazságügyi területen illetékes szerveket vonta be a munkába. ${ }^{7}$

A munka egyik eredményterméke az Európa Tanács Moneyval országjelentésben Magyarország részére megfogalmazott, pénzmosás elleni ajánlások végrehajtásáról készített akciótervrôl szóló 1688/2017. (IX. 22.) Korm. határozat, amely felsorolja a különbözô intézmények illetékességi körébe tartozó feladatokat és határidôket. 
AZ ORSZÁGJELENTÉS ALAPJÁN VÉGREHAJTOTT JOGSZABÁLYI VÁLTOZÁSOK

A 2016 szeptemberében publikált Moneyval országjelentés után, Magyarországnak a 2017. december 5. és 7. között megrendezett plenáris ülésen kellett bemutatnia a pénzmosás és terrorizmusfinanszírozás szabályozási környezetével kapcsolatos változtatásait. $\mathrm{Az}$ alábbiakban nézzük azon főbb intézkedéseket, amelyek szervesen illeszkednek a Moneyval országjelentésben megfogalmazott ajánlásokhoz.

1. A pénzmosás és a terrorizmus finanszírozása megelôzésérôl és megakadályozásáról szóló 2017. évi LIII. törvény rendelkezései kiterjednek valamennyi kockázatot hordozó szereplôre, elsôsorban az ügyfél-átvilágítás, tulajdonosi információk központi nyilvántartása, pénzátutalásokkal kapcsolatos adatokra, továbbá a felügyelet tekintetében.

2. Az Európai Unió és az ENSZ Biztonsági Tanácsa által elrendelt pénzügyi és vagyoni korlátozó intézkedések végrehajtásáról szóló 2017. évi LII. törvény a kockázatokat hordozó szereplók szankcionálása kapcsán tartalmaz rendelkezéseket. Vagyonbefagyasztással és egyéb pénzügyi korlátozó intézkedésekkel szervezetek vagy teljes országok mozgásterét lehet leszúkíteni, és időlegesen leállítani az állam nemzetközi jogokba ütközố tevékenységét, esetleg expanziós törekvéseit. ${ }^{8}$

3. A külföldról támogatott szervezetek átláthatóságáról szóló 2017. évi LXXVI. törvény az egyesületek és alapítványok gazdálkodását teszi átláthatóbbá, mivel a törvényben meghatározott, külföldrôl érkezô támogatás esetén a szervezeteknek bejelentési kötelezettségük van a székhely szerinti illetékes törvényszék irányába.
4. Bôvült a Magyar Nemzeti Bank szerepkörét erôsítô jogszabályok köre, amelyet a Magyar Nemzeti Bank 19/2017. (VII. 19.) rendelete, valamint a Nemzetgazdasági Minisztérium 21/2017. (VIII. 3.) rendelete erósített meg. A 2010-es évet követóen a Magyar Nemzeti Bank szerepvállalása túlmutat az árstabilitás biztosításán, és nagyobb figyelmet kapott a gazdasági növekedéssel, a pénzügyi stabilitással, illetve a társadalmi stabilitással kapcsolatos felelôssége (Lentner, 2015:37). A pénzügyi stabilitás pedig többek között olyan előfeltételekre épül, mint a belsố és külsố sokkoknak való ellenálló képesség és a kockázatok ismerete. Ha a gazdasági alrendszer átlátható, nincsenek „fekete foltok”, megteremthető a fenntartható fejlódés. Ennek érdekében fel kell lépni minden olyan szereplóvel szemben, amely a szürke- vagy feketegazdaságot erôsíti (pénzmosás), vagy a társadalom kohézióját és politikai rendszerét destabilizálja (terrorizmus). Nemzetközi példákon keresztül látható, hogy olyan országokban, ahol a pénzügyi rendszer nem átlátható vagy rosszul szabályozott, ott nagyobb teret hasít ki magának a szervezett búnözés, a radikális/militáns csoportok, az embercsempészet, valamint a fegyver- és drogkereskedelem. A pénzügyi rendszer stabilitásának megốrzése mellett a nemzetbiztonság is megkívánja a fenti tényezók kiiktatását vagy minimálisra lecsökkentését, hiszen az adott ország politikai alrendszerének szervezése és a társadalmi viszonyok javítása enélkül nem végezhetô eredményesen.

5. A gazdálkodási tevékenységet végzô társaságok, valamint a civil szervezetek (egyesületek, alapítványok) 2018. január 1-jétool kötelesek az úgynevezett Cégkapu felületén regisztrálni, és a késôbbiekben 
azon keresztül lebonyolítani az elektronikus ügyintézést.

A Moneyval elismerte, hogy Magyarország rövid idô alatt „dicséretes előrehaladást" tanúsított, és számos terület besorolása javult (Moneyval, 2017:10). Ugyanakkor bizonyos területek még további intézkedéseket követelnek, éppen ezért a Moneyval 2018. decemberi plenáris ülésén Magyarországnak ismételten alkalma lesz alátámasztani a jogrendszer fejlesztésére irányuló erőfeszítéseit.

Magyarország nemzetközi vizsgálata a Moneyval plenáris ülésével nem ért véget, mivel vele párhuzamosan a FATF is megfigyelés alá vonta Magyarországot. A FATF célja nem kevesebb, mint világszinten elfogadott standardok kidolgozása a pénzmosás és terrorizmusfinanszírozás tekintetében. A standardizálás elốnye, hogy az országok erőfeszítései összehasonlíthatóvá válnak, ezáltal nyomon követhetốk az egyes országok vagy országcsoportok által hordozott kockázatok.

Ugyanakkor módszertani szempontból látni kell a FATF standardizálásának, valamint az egyes országok besorolásának korlátait. Az egyes vizsgált országok jogszabályi környezete, politikai kultúrája ugyanis jelentôsen eltér egymástól. Az Európai Unió bármely tagállamában a pénzmosással és terrorizmusfinanszírozással kapcsolatos intézkedések sokkal hatékonyabban fejtik ki hatásukat, mint kevésbé jól szervezett, esetleg törékeny államok esetében. A törékeny államok egyik közös jellemvonása, hogy a központi kormányzat nem gyakorolja az ország teljes területe felett az ellenôrzést, ennélfogva hiába kerülnek különbözố jogszabályok bevezetésre, azok nem érvényesíthetôek mindenhol.

Mindazonáltal vitathatatlan, hogy nemzetközi színtéren a FATF döntố szere- pet játszik a pénzmosás és terrorizmusfinanszírozás vizsgálata kapcsán, ennélfogva az egyes országok nemzetközi megítélését is képes befolyásolni. Amennyiben stratégiai szintû́ hiányosságokat vél felfedezni, megkezdódik az International Co-operation Review Group (ICRG) eljárás, ebben az esetben pedig joggal feltételezhetô az érintett országról, hogy a pénzügyi rendszere kockázatokat hordoz. ${ }^{9}$

\section{Összegzés}

Magyarország földrajzi helyzetéból adódóan számos kockázati tényezônek ki van téve, ennélfogva nem meglepó, hogy a nemzetközi szervezetek, így az Európa Tanács vagy az FATF szigorúan vizsgálja a pénzmosással és terrorizmusfinanszírozással összefüggố szabályozási környezetet. Az országjelentés hatására az átfogóbb intézkedések a 2017. évben, illetve 2018. januári hatálybalépéssel megvalósultak, azonban számos területen szükséges további változásokat eszközölni. A 2018. április országgyúlési választások következtében várhatóan lassulni fog a szabályozási környezet fejlesztése, így a pénzmosással és terrorizmusfinanszírozással kapcsolatos intézkedési „kötelezettség” átnyúlik az új kormány elsố évére.

A pénzmosással és terrorizmusfinanszírozással szembeni küzdelem folyamatos odafigyelést igényel az államok részérôl, minthogy az állam alatti szereplók - nemzetközi hálózattal rendelkezó búnszervezetek és terrorista csoportok - egyre nagyobb kihívást jelentenek. Az Európai Unió közvetlen földrajzi környezetében - Észak-Afrika és Közel-Kelet - egyre több olyan ország jelent meg az elmúlt években, amelyek magas kockázatúak, és a vizsgált téma szempontjából 


\section{Tudományos múhely}

egyre nagyobb odafigyelést igényelnek. A pénzmosással és terrorizmusfinanszírozással összefüggó szabályozási környezet fejlesztése ennélfogva minden uniós tagállam elemi érdeke, amely nemcsak a gazdasági biztonságot erôsíti, hanem más alrendszerekre is kihatással van, végsố soron pedig a fenntartható fejlódés megteremtését segíti elô.

\section{JEGYZETEK}

1 Az általánosan elfogadott paradigmával szemben kritikusan fellépố hangok nem magyar sajátosság. A 2008-2009-es gazdasági világválság nyomán született válságkezelési mechanizmusok unortodox elemeket is tartalmaztak, és egyre nagyobb igény fogalmazódik meg nemzetközi szinten is arra, hogy a neoklasszikus paradigmából kilépve más elméletek hangsúlyt kapjanak (lásd Elliot, 2017).

2 A fốbb eredmények: 2013-ban bevezették az egységes makro- és mikroprudenciális intézményi rendszert, gazdasági alrendszer és hitelezési piac élénkült a Növekedési Hitelprogram segítségével, a PSZÁF funkciói és tevékenységi körei integrálódtak, felügyeleti szerepköre erôsödött.

3 Forrás: http://reports.weforum.org/globalcompetitiveness-index-2017-2018/competitiveness-rankings/\#series=EOSQ035.

4 A Moneyval 2015-ben 110,100 milliárd euró összegre becsüli a gazdaságban a készpénzállomány mennyiségét.

5 Az Európa Tanács állandó monitoringtevékenységét végzô szerve, amelynek 47 tagállama van, köztük Magyarország is.

6 A Központi Statisztikai Hivatal 2015. évi adatai alapján a 62152 nonprofit szervezetből 54401 minôsül civil szervezetnek, és szervezetenként átlagosan 10 millió forinttal gazdálkodtak (természetesen a valóságban nagyon egyenlôtlen a bevételek megoszlása). Forrás: www.ksh.hu/docs/ hun/xstadat/xstadat_eves/i_qpg005a.html.

7 A munkába bevont szervek: Belügyminisztérium, Emberi Erôforrások Minisztériuma, Igazságügyi Minisztérium, Külgazdasági és Külügyminisztérium, Nemzetgazdasági Minisztérium, Országos Rendôr-fôkapitányság, Terrorelhárítási Központ, Nemzeti Védelmi Szolgálat, Nem- zeti Adó- és Vámhivatal, Információs Hivatal, Alkotmányvédelmi Hivatal, Nemzetbiztonsági Szakszolgálat, Terrorelhárítási Információs és Bûnügyi Elemzô Központ, Legfôbb Ügyészség, Országos Bírósági Hivatal. Forrás: NGM (2017).

8 Törékeny országokat sújtó szankciók listája az Európai Unió, valamint az Egyesült Államok részérôl: www.bscn.nl/sanctions-consulting/sanctions-list-countries.

$9 \quad$ Az ICRG-eljárás során feltárták az adott ország pénzmosással és terrorizmusfinanszírozással kapcsolatos kockázatait. Ebbôl a nézôpontból ugyan nem különbözik a Moneyval tevékenységétôll, viszont míg az Európa Tanács regionális, addig az FATF globális nemzetközi szervezet. Így nem meglepó, hogy az ICRG-vizsgálatok eredményei ráhatással lehetnek az adott ország nemzetközi megítélésére, amely végsô soron a gazdasági fejlôdésére is kihatással lehet. Az ICRG-vizsgálat a kockázatokat hordozó országok esetében kétféle, kevésbé kedvezô eredményre juthat. Az úgynevezett Public Statement címú dokumentumot a legkockázatosabb országok esetében bocsátják ki, jelenleg Irán és Észak-Korea esetében van érvényben. Az Improving Global AML/CFT Compliance: Ongoing process címú dokumentum kibocsátása esetén stratégiai szintû́ hiányosságokat állapítottak meg a vizsgálat során. Jelenleg Afganisztán, Bosznia és Hercegovina, Etiópia, Irak, Laosz, Szíria, Uganda, Vanuatu és Jemen szerepel a listán.

\section{FELHASZNÁLT IRODALOM}

Drog Fókuszpont (2017): 2017-es Éves Jelentés (2016os adatok) az EMCDDA számára. „Magyarország". Nemzeti Drog Fókuszpont, http:// drogfokuszpont.hu/wp-content/uploads/ EMCDDA_Jelentes_2017.pdf.

Elliot, Larry: Heretict Welcome! Economics Needs a New Reformation. The Guardian, 17 December, www.theguardian.com/business/2017/ $\mathrm{dec} / 17 /$ heretics-welcome-economics-needsa-new-reformation?utm_source $=$ mandiner\& utm_medium=link\&utm_campaign $=$ mandiner_201801.

Gál István László (2016): A terrorizmus finanszírozásának fogalma és technikái a XXI. században. Szakmai Szemle, 14. évf., 2. sz., 81-98.

Kondor Zsuzsanna (2017): 1. modul - Kohéziós politikai alapismeretek. In: Nyikos Györgyi (szerk.): 


\section{Tudományos múhely}

Kohéziós politika 2014-2020. Az EU belsố fejlesztéspolitikája a jelen programozási idôszakban. Dialog Campus Kiadó, Budapest.

Lentner Csaba (szerk.) (2015): Adózási pénzügytan és államháztartási gazdálkodás. Közpénzügyek és államháztartástan II. NKE Szolgáltató Kft., Budapest.

Lentner Csaba - Zémán Zoltán (2017): A pénzmosás egyes jogi és gazdasági összefüggéseirôl. Miskolci Jogi Szemle, 12. évf., 1. sz., 19-32.

Moneyval (2016): Anti-money laundering and counter-terrorist financing measures, Hungary. Fifth Round Mutual Evaluation Report. European Council, September, www.fatf-gafi.org/ media/fatf/documents/reports/mer-fsrb/ MER-Hungary-2016.pdf.
Moneyval (2017): Committee of Experts on the Evaluation of Anti-Money Laundering Measures and the Financing of Terrorism. Meeting Report, Moneyval, December, https://rm.coe.int/reportof-the-55th-plenary-session-/16807829c6.

NGM (2017): Összefoglaló dokumentum a pénzmosás és a terrorizmus finanszírozása kockázatairól szóló Nemzeti Kockázatértékelés felülvizsgálatáról. Nemzetgazdasági Minisztérium, http://ngmszakmaiteruletek.kormany.hu/download/6/3c/ f1000/Kockazatertekeles_AMLCFT_2017.pdf.

Simon János (szerk.) (2016): Huszonöt éve szabadon Közép-Európában. Cepoliti Kiadó, Budapest.

Tóth Zoltán Balázs (2016): A minisztériumok védelmi felkészítése. Nemzetbiztonsági Szemle, 4. évf., 1. sz., 100-115. 


\section{The Choice and Organization of Materials in the Communicative Minimum for Teaching Communication to Students With a Non-Humanities Profile}

\section{SUMMARY}

The question of the activities approach to the choice and organization of materials in the communicative minimum for textbooks for teaching students with a nonhumanities profile has been researched on three levels: macro, medium and micro. The history of the choice of contents of teaching and its organization in communicative minimum are described. The recommendations to take into consideration the results of research, when choosing materials to the communicative minimum for teaching students of non-humanities profile within the limits of training well-educated and well-mannered students of nonhumanities profile have been worked out.

Keywords: content of teaching, choice of materials, types and kinds of communica- tion, forms and functions of communication, activities approach

In 1966, the minimum vocabulary for Ukrainian schoolchildren was selected by V. D. Arakin, V. M. Lubimova, I. V. Rahmanov, G. M. Uizer, S. K. Folomkina and V. S. Tsetlyn. Later on, this selection was re-edited and re-published. The suitability of the chosen lexical units for promoting the process of communication was defined indirectly, based on features such as "semantic value" and "combinability", and they were not stylistically delimited. Lexeme features like polysemy, word-formation value, suitability for forming other units and frequency were taken into account. Despite thorough scientific grounding, the modern understanding of the tasks related to teaching communi-

Bronislava Rubinska, PhD in Pedagogy, Associate Professor of the Department of European Languages, Kyiv National University of Trade and Economics, Ukraine. 


\section{Tudományos múhely}

cation requires correction in some of the principles, such as 1) the exclusion of synonyms, 2) the obligatory stylistic neutrality of the units used in education.

Further development in the theory underlying the choice and organization of language materials was implemented within the limits of the communicative approach to teaching foreign languages. It was applied to German and English by I. L. Bim (1979) and by V. D. Arakin, respectively. A distinction was made between structural and functional language models. The basis was the linguistic theory focusing on variability as the main (but not the only) difference between a phrase and a sentence, formally expressed with the help of intonation. Many other differences between a sentence and an utterance were not taken into account.

The development of structural and functional approach allowed the introduction of the level of supra-phrasal unity and text. Structural and functional types of micro-dialogues and communicative types of monologues were singled out.

The modern understanding of the term "function" does not only cover the function of a language unit, but also the speaker's function in trying to express thought more accurately and to influence the partner in communication, which enables a more complete application of the communicative approach to the teaching of foreign languages.

The application of the communicative approach to the choice and organization of materials slowly transfers this problem from the creation of vocabulary and grammar minimums to the theory of program and textbook creation. Thus the subdivision between lexis and grammar is removed, and the correlation between communicative tasks and the teaching material is applied. The necessity to correlate the language system with communication arises. But the system of teaching communication in the methods of Teaching Foreign Languages still needs improvement in terms of the content of teaching foreign languages. There is still a number of questions regarding the choice and organization of materials. These include a more exact general approach to this problem and the identification of the features of textbook material selection and organization for teaching students of non-humanities profiles. The generalization and development of the existing approaches in this research are related to the consistent consideration of all system-forming characteristics of communication on the one hand, and the use of research data in pragmalinguistics on the other, with the aim to bring foreign language teaching to high-school students of non-humanities profiles closer to their actual needs and to strengthen its educational impact. This problem is viewed from an activities approach, which makes choice more specific.

Improvement in the content of teaching foreign languages in higher education is related to successive uses of the activities approach in teaching. Students' activities have become considerably more colourful over the decades. After Ukraine's adoption of the EU system of education and has been participating in the Bologna process, students were given the opportunity to study abroad, participate in international projects, conduct scientific research and report about the results at the international conferences and symposiums. However, this analysis has shown that bachelors and masters 


\section{Tudományos múhely}

have certain difficulties in communication in some areas, including scientific fields. This is due, among others, to the fact that the question as to what to teach has been studied insufficiently.

The aim of this article is to show successive steps in the choice and organization of materials in communicative minimum in textbooks for students studying subjects other than humanities. Let us first consider the concept of "teaching content". There is no unanimity in the definition of this concept. According to the authors of the book "Contents of Teaching Foreign Languages at School", there is no exclusive answer to the question "What to teach?" (Klimentenko et al., 1984). Based on pedagogical principles and on communication theory, T. Y. Mironova gives the following interpretation of the term: construction of contents of teaching of foreign languages, which is aimed at peculiarities of communication surely corresponds to the demands of modern society. So it is necessary not only to investigate general problems of communication but also communication of every concrete group of communicating people" (Mironova, 1985). This understanding of the term was used in this research of communication by students of trade and finance. This requires the selection of a) those parameters of communication that can be introduced into the process of teaching foreign languages; b) the way they can be combined in this process; c) the correlation of super-induced parameters of real-life communication with the principles of pedagogical activity. The term "contents of teaching foreign languages" and content selection must be viewed from the perspective of communication activities, and the requirements must be set up for the choice and organization of materials in textbooks. The following tasks need to be accomplished:

- consideration of the factors which characterize the communication of BA and MSc students of finance and must be taken into account to ensure completeness of the choice of language materials and their efficacy;

- identification of language materials that provide the above mentioned characteristic features for classroom communication;

- work out the requirements to the choice and organization of language materials into a communicative minimum, that will provide communication needs of this group of students.

Firstly, the concept of "communication" has a lot of various interpretations used by scientists (Skalkin, 1983; Klimentenko et al., 1984; Passov, 1980). In Russian and Ukrainian there are two synonyms. In some works it is used in the meaning of a theory, while in others it is a synonym for communication as a discipline, and as students' language use characterized by creativity, purposefulness and interrelationship between the communicators. The polysemy of the meanings of the term is the reason for confusion. In this essay, I agree with the definitions that take communication for an exchange and transfer of information, which may be face-to-face or mediated, results in the influence of one speaker on another one.

As the various types of communication are discussed in detail in psychology, more specifically, social psychology and the theory of interaction, this research was based on their findings. The function of communication is the organiza- 


\section{Tudományos múhely}

tion of interaction, i.e. regulation of the participants' activities that fit into to their mutual or individual plans. The role of speech is the mediation of efforts at the participants' activity regulation. Partners exchange information in order to change each other's activity. In an interaction both communicators are equally active, while in the case of influence only one is active. "If the need in communication is mainly realized in the process of intercommunication by the subject of communication, in the process of influence it is different. In the latter it is the need of self-establishment, self determination of the leader. ...The aim of the process of interference is such integration of partners' activities, that can be characterized as cooperation" (Academy of Sciences of the USSR, 1983). Any interaction presupposes both reciprocity and opposition.

As the underlying processes of communication are interaction and influence, the informative nature of the communication process is not denied, but we consider it secondary in the process of serving mutual activities. The communication of the analysed students is related to their typical activities, regulated by social requirements and control on the part of their professors. These are:

a) their work during future professional activities in a bank or financial institution;

b) mutual creative activities;

c) their studies;

d) their scientific work. Thus their mutual speech activities are also reduced.

The analysis of psychological research papers and books reveal that communication is a very complex phenomenon with a hierarchal structure. Psychologists analyse communication on three levels: the highest (macro-), medium (mezo-) and the lowest (micro-) level. In this approach, students' activities can be considered on the level of activity, detailed actions and separate associated actions, if we want to identify their imminent characteristics and the selection requirements in a communicative minimum. Under "communicative minimum" we mean a set of spheres, situations (acts of speech) and a set of language units that provide their implementation. So we will start this analysis with macro level. Here we were mostly interested in communication of students with other people that can be characterized by most typical themes and spheres of communication.

The concept "sphere of communication" is also understood in various ways: psychology, linguistics and the methods of teaching foreign languages at higher school consider this expression from their own professional point of view. For the purpose of this study, I rely on the definition proposed by V. L. Skalkin (1983), based on the concept of "situation": communication is a set of situations. Various spheres are distinguished: social and domestic, family, professional, socio-cultural, social activity, law and administration, and spectacular-mass. It is not explicitly expressed, but this nomenclature can be implicitly associated with practice and the intellectual activity of communicators. Thus the spheres of communication can be considered from the perspective of student activities, and in a broad sense, the main type of activity, namely, studies and scientific work. Whichever definition is chosen, in terms of oral communication a student is the subject of the activity, or the centre of this space. This peculiarity of the term differentiates it from the concept of 
'theme', which characterizes the line segment of reality without any dependence on the speaker (Vaisburd, 1981). Thus if a student's active position in speech activity is to be defined, the sphere of communication must be taken as a starting point to consider the theme as a structural element of the situation and define the subject of the conversation.

Due to the high importance of spheres, we can propose the first requirement to the choice and organization of materials in communicative minimum: representation of the spheres of communication, typical for a student contingent, in this case, MA students of finance. As the classification of spheres proposed by V. L. Skalkin (1983) can be referred to any contingent of students, we have to specify the contingent.

Another task is to select situations within the analysed sphere. This analysis has shown that the situations proposed by the authors of textbooks stimulate only one or two types of activities: listening and speaking. However, recent trends also require consideration for the didactic principle of integration. The implementation of the integration principle and other didactic principles to prevent discrepancy between the contents of education and pedagogical reality requirements a) the singling out of the communication parameters that can be introduced into the teaching process, b) defining the way the individual parameters can be combined and integrated into simulated classroom communication; $c)$ the correlation of the introduced parameters with the principles of practical pedagogical activity.

At the intermediate level, typical student contacts must be analysed within the chosen spheres. To solve the problem we have to consider the typological characteristics of communication, namely, the types, functions and forms of communication. In classroom communication one of them can be picked to be treated as the principal one, taking the stage of education into account. Below is a description of the typological characteristics in interaction with each other.

In modern psychology different types of communication are distinguished: socially oriented, subject-oriented and interpersonal. In socially oriented communication the most typical activities performed by students of non-humanities are making public addresses, reports and short lectures, either in one's native tongue or in a foreign language. Foreign languages are mainly used for establishing business and scientific contacts with foreigners. Students are involved in the latter during classroom activities. In order to bring the process of education closer to the needs of real-life communication students need to be involved in situations where they are required to act as the subject of communication, whether initiators or organizers, in the process of interaction with other participants of activities. This means that the teaching material must be selected with consideration to socially oriented and group focus types of communication, and its functions, forms and types.

Communication focused on a group presumes joint activities performed to meet group needs, helps to organize group activities and solves the set group objectives. For MA students participation in joint activities is related to their studies, involvement in joint projects and scientific seminars, webinars, conferences and symposiums.

In psychological papers and articles it 


\section{Tudományos múhely}

is stated that subject-oriented communication is insufficiently researched. However, this research is based on characteristics such as:

1) a common goal, which unites the efforts of participants of a joint subjectoriented activity;

2) the existence of a common goal defines and differentiates specific tasks of each of its participants. It is made specific in certain tasks entrusted on each participant, and can be implemented only in line with joint actions;

3) speech acts (SA) implemented by the participants of joint activities differ from individual SAs, since they are all interconnected, each not only based on individual acts, but necessarily takes into account the presumed future acts of all other participants of the activity (assistance or counteraction). In the process of mutual activity realization the acts of its individual is regulated both by the reflection of the object it is aimed at but also the actions performed by other participants, and those changes in the object which are the result of it. The acts of an individual are thus built not only in accordance with the correspondence to the task and object. Private party "adapts" the action performed by other people. The regulation of an individual act includes the moment of "adaptation". It increases such characteristics of action as "dynamics". Finally, the evaluation of result comply with the demands that are determined by agreement of "mutuality" of joint activities (Manko, 1979).

Another aspect of this research is the study of the roles of communication. It helps to present the planned result of schooling as an ability to implement the main functions of communication.
In communication theory the following functions are distinguished: informational-communicative, regulatory-communicative and affective-communicative. In methods of teaching foreign languages these functions were defined by I. L. Bim as cognitive, regulative, value-oriented and conventional (Bim, 1979). The research presented in this essay is based on classification, and enables us to present the planned results of training. Distinctions is purely theoretical, as all these functions are interrelated in real-life communication. "Cognitive function" is seen as the process of transferring and receiving information. It is in one way or another related to people's activities focused on the conditions and means of its implementation. Even thinking processes proceed faster under condition of constant informational communication.

For students the implementation of the cognitive function correlates with their studies and can be successful if they pass credits, examinations, defend course and diploma papers. The regulatorycommunicative function is implemented in the process of behaviour, whether of the student or of someone else. "In the process of communication. In the process of communication an individual can influence the motive, aim, program, decision-taking, execution of several acts and their control, i.e on all components of his partner's activities. In this process mutual stimulation and correction of behavior is realized. This influence can be very deep and influence a personality as a whole (Vaisburd, 1981). The regulative function may be manifest in the form of a call to action or to finish an action, as in a recommendation, appeal, order, or motto. Their meaning is known to every- 


\section{Tudományos múhely}

one since childhood. Another implementation of this function is interdiction. The first thing a small child understands is impossible and possible. In their future a lot depends on how well students have understood social interdictions. The third implementation of the regulative function, destabilization, is special, as it has evolved during the history of civilization. Every human being does work in favour of or against other people. This function is used in everyday life in the form of reproach, threat and accusation.

The third function is value-orientation. It is related to the desire to communicate with friends, maintain friendly relationship, based on mutual interests, joint activities.

The fourth function is the conventional one. It is implemented according to the norms of behaviour accepted in the society where the student lives.

Under certain conditions one of the functions can become picked as the main one. For example, in a joint activity, the regulative function is the leading one, as it reflects the active position of the communicators, their intention to influence others with the aim of changing their actions and plans, and it can be implemented in the form of a call to actions, an interdiction of actions, the organization of joint actions, the correction of other participants' actions, and so on. In the process of joint activities, information is exchanged directly or via social networks, and the evaluation of results is focused on getting a regulatory effect.

The syntactic features of informational descriptive monologues include the use of homogeneous parts of the sentence, sentences with compound nominal predicates. Verbs of existence and the presence of something are used as predicates. The most typical grammar structure is introduction - a phrase introducing the subject, event, phenomenon on the whole, or the statement of its presence. This is followed by details, the characteristics of a given person, and the subject or phenomenon of reality. These are given in words and phrases that specify and clarify the concepts given in the introductory part. The end of the monologue can reassert the presence of a person, subject or phenomenon or the selected symptoms or characteristics or information about the exhaustion of the selected symptoms or characteristics. All descriptive informative dialogues should be viewed as a single structural unit consisting of elements such as 1 introduction of a phenomenon, persons, events and subjects; 2 characteristics of this phenomenon, person, event or subject, 3 generalization or concretization of the introduced characteristics.

In narrative monologues, the use of sentences with predicates of action is the most typical. Informative monologues and narrations (information, story) are organized as the transfers of successive actions. Predicates in them are expressed with the help of verbs of action, which change each other in turn, and subordinate modifiers are the words which show the time and place of action. A narrative monologue starts expressed with a phrase introducing the event or subject of the action, or the place and time of the action. The expressions of event development contain predicates reflecting certain segments of actions not accompanied by speech in time and space. The final phrase of a monologue shows either the end of these actions with the help of 


\section{Tudományos múhely}

predicate about the result of the action or a change in the place and time of the subjects of action, as expressed by subordinate modifiers of time and place in space semantics.

Thus the following characteristic features of communicative activity need to be taken into account when evaluating communicative minimum for students of non-humanities subjects:

- representation of the spheres and situations of communication, typical for the student contingent it is meant for. In this research it is meant for MA students of finance.

- suitability for all four functions of communication; tion;

- access to three types of communica-

- representation in the minimum of speech units, relating elementary text units to the detailed text.

The extent to which the units can meet the above requirements has been evaluated on the basis of their effective force potential.

\section{REFERENCES}

Academy of Sciences of the USSR (1983): Speech Communication: Problems and Perspectives. Collection of scientific analytical reviews, Academy of Sciences of the USSR, Moscow (in Russian).

Bim, I. L. (1979): Some Problems of Teaching Dialogue Speech. Foreign Languages at School, No. 5, 20-27 (in Russian).

Doroshenko, A. V. (1986): Incentive Speech Acts and their Interpretation in the Text (on the Material of the English Language). PhD Thesis in Philological Science, Moscow Institute of Foreign Languages, Moscow, 26 (in Russian).

Fastovets, R. V. (1985): Methods of Teaching Oral Foreign Language Communication at the Beginning Stage in a Language University (on the material of the English Language). PhD Dissertation in Pedagogical Science, Kyiv Institute of Foreign Languages, Kyiv, 223 (in Russian).

Karimova, L. A. (2009): Contents and Technologies of Teaching Foreign Languages in Conditions of Modernization of Higher Professional School. On the Example of Non-humanities Profile Universities Participants of the Bologna Process. PhD Thesis in Pedagogical Science, Kazan, 230.

Klimentenko, A. D. et al. (1984): Contents of Teaching Foreign Languages at School. Organization of Speech Activity. Pedagogics, Moscow (in Russian).

Kornayeva, Z. V. (1982): Organization of Teaching Dialogue Speech in the 4-5 Forms of a Secondary School (on the material of the German Language). PhD Dissertation in Pedagogical Science, Moscow Institute of Foreign Languages Moscow (in Russian).

Manko, Y. N. (1979): To the Question of Level Analysis of Social Influence on the Formation of Socially Active Position of a Pupil. Problems of Psychological Influence. Ivanovo State University of the First in Russia Ivanovo-Voznesensky City-wide Soviet of Workers' Deputies, 30-40 (in Russian).

Mironova, T. Y. (1985): Teaching Oral Expressive Speech in the Intensive Course of a Foreign Language (Problems of the Contents of Teaching). $\mathrm{PhD}$ Dissertation of Pedagogical Science, Institute of Foreign Languages, Moscow (in Russian).

Passov, Y. I. (1980): The Definition of the concept "communicative method". In: Problems of Communicative Teaching of Foreign Language Activity. Volume 208, Voronezh State Pedagogical Institute, Voronezh, 26-39 (in Russian).

Skalkin V. L. (1983): Situation, Theme and Text in Linguistic-methodological Aspect (Organization of Material for Oral Speech). Russian Language Abroad, No. 3, 52-58 (in Russian).

Vaisburd, M. L. (1981): Typology of TeachingSpeech Situations. In: Klimentenko, A. D. - Moskalska, O. I. (eds.): Psychologicalpedagogical Problems of Teaching Foreign Languages. Research Institute of Contents and Methods of Teaching of the Academy of Pedagogical Science of the USSR, Moscow, 8191 (in Russian). 
A Polgári Szemle 2ol 7-es tartalomjegyzéke

Árva László - Mádi László - Az élômunka terheinek

$2017 / 4-6$.

98

csökkentése az egészségbiztosítási rendszer

finanszírozásának átalakítása révén

Bábosik Mária - Innovációs terek és technológiai fejlôdés.

2017/1-3.

Tudományos parkok Tajvanon

Balassa Bence - Egy dicstelen történet. A dehumanizáció

$2017 / 1-3$. karrierje a 20. században

Balassa Bernadett - Hatékony helyi gazdaságfejlesztés a Biblia alapján és napjainkban

Bánfai Edina - Bujtár Zsolt - Ferencz Barnabás -

2017/1-3.

Lehetôségek és veszélyek az offshore-jelenségben

Becsey Zsolt - Makrogazdasági adatok az Európai Bizottság jelentéseinek függvényében

Bencsik András - A fogyasztóvédelem gazdaságelméleti alapjairól

Bertalan Péter - Nyitás Kelet felé

$2017 / 1-3$.

2017/1-3.

$2017 / 4-6$.

Bethlendi András - Államcsốdök - zavaros vizeken?

$2017 / 4-6$. 411

$2017 / 4-6$.

Botos Katalin - Közgazdasági tételek, amelyek áttörésre

$2017 / 4-6$. várnak

Bruckner Éva - Vagon- és barakkvárosok. A trianoni utódállamok menekültjeinek életkörülményei

Bukovics, István- The "Good State": Outline of the Last Three Years of Research

Cziczka Katalin - Luther és Kálvin jogfilozófiai és

2017/1-3.

$2017 / 4-6$.

politikai filozófiai nézetei. Recenzió a Reformáció, államhatalom, politika címú kötetrôl (Birkás Antal könyvéról)

Czimbalmos Róbert - Kovács Györgyi - A diverzifikáció és a multifunkcionalitás lehetôségei Jász-NagykunSzolnok megye gazdálkodói körében

Cservák Csaba - Az alapvetó jogok biztosa nemzetközi összevetésben

$2017 / 4-6$.

2017/1-3.

188

Donka Attila - Gyuricza László - Az állam szerepe az aktív turizmus fejlesztésében

Fekete Dávid - A Modern Városok Program elemzési lehetôségei

Fekete Dávid - Felsôoktatási és Ipari Együttmúködési Központ Gyôrben

2017/4-6.

2017/1-3.

176

2017/1-3.

2017/1-3. 106 
Fekete Dávid - A nagyvárosi régiók múködésének

$2017 / 4-6$.

fenntarthatósága az EU-ban

Feketéné Czakó Katalin - Felsôoktatási intézmények és

$2017 / 1-3$. vállalkozásfejlesztés

Golovics, József- Contemporary Realism in Theory and

2017/1-3. 362 Practice. The Case of the Ukrainian Crisis

Gróf Bethlen István - A kálvinizmus szerepe a modern gazdaság kialakulásában

Gulyás Éva - Magyar és német tapasztalatok a xenofóbia terén

Halász Vendel - Az egyéb érdekeltek jogi védelme az Európai Unió vállalatfelvásárlási szabályozásában

Halász Vendel - A stakeholder elmélet és megjelenése az európai államok társasági jogában

Hamza Gábor - Szent István törvényei európai összefüggésben

Horbulák Zsolt - Határforgalom Csehszlovákia és Magyarország között Csehszlovákia pártdokumentumai alapján

Huszti Ernố - A magyar modell történeti, jelenkori és

$2017 / 4-6$.

2017/1-3.

2017/1-3.

$2017 / 4-6$.

2017/1-3.

$2017 / 1-3$. nemzetközi dimenzióban. Továbbszôtt gondolatok Lentner Csaba Rendszerváltás és pénzügypolitika címú könyvéról

Iván Dániel - Koi Gyula - Bibliográfia az alkotmányról, az államról, az Országgyúlésrôl, a központi állami szervekrôl és a választási rendszerekrôl

Iván Dániel - Koi Gyula - Új Btk. kommentár I-VIII. kötet (frissítésekkel)

Iván Dániel - Koi Gyula - Állam és jog az ellentétek földjén I. A Közel-Kelet és az iszlám joga

Járosi Márton - Kovács Pál - Az energiaunió és a tagállami felelősség

Kecskés András - A szuverén alapok önszabályozási

$2017 / 1-3$. 407 mechanizmusa - a Santiago-elvek

$2017 / 4-6$.

$2017 / 1-3$.

$2017 / 4-6$.

$2017 / 4-6$.

$2017 / 1-3$.

Kecskés András - Bujtár Zsolt - A kínai pénzügyi rendszer

$2017 / 4-6$. árnyéka. Árnyékbankrendszeri kockázatok a kínai gazdaságban

Kecskés András - Ferencz Barnabás - A francia és a német $2017 / 4-6$. 202 társaságirányítás történeti és jogi tényezôi 
Kollár Csaba - Emlékeink lenyomatainak

$2017 / 4-6$.

információbiztonsága. Hogyan ôrizhetôek meg és

írhatóak át emlékeink a digitális korban?

Kolozsi Pál Péter - Lentner Csaba - Parragh Bianka -

$2017 / 4-6$.

Közpénzügyi megújulás és állami modellváltás

Magyarországon

Kopátsy Sándor - Az Európai Unió jövője

$2017 / 4-6$.

Koudela Pál - A kínai diaszpóra

$2017 / 1-3$.

Kovács Kristóf - Az Opus Deitôl a Provida Materig.

2017/1-3.

Állambiztonsági hálózatok és egyházi kisközösségek

(Bertalan Péter könyvérôl)

Kucherenko, Diana- Integration of the Ukrainian Higher

Education Into the Global Educational Space

Lentner Csaba - Ellenség a kapuk elôtt - Fôszerkesztői

beköszöntô

Lentner Csaba - Hiánypótlás - Fôszerkesztői beköszöntő

Maróti Dávid - A Második Osztrák Köztársaság az átmeneti idôszakban

Mihály Nikolett - Komáromi Nándor - Rónai Ramóna -

$2017 / 4-6$.

$2017 / 1-3$.

$2017 / 4-6$.

2017/1-3.

392

2017/4-6.

160

Bruder Emese - Demográfiai és szociálpszichológiai

hatások az életszínvonal minimális és ideális

szintjének megítélésében

Nizalowski Attila - Egy nép, melyet tenyerén hordott

az Isten. A lengyel felvilágosodásról Kościuszko

halálának 200. évfordulóján

Novoszáth Péter - Karcsúsított kormányzás és

rezsicsökkentés

Odorige Catherine Enoredia - Historical Perspectives of African

Nationalism: with Focus on Nigeria

Paksi-Petró Csilla - Új és korszerú módszerek a

közigazgatási vezetôk képzésében

2017/1-3.

2017/1-3.

Pataki János István - A bírósági végrehajtás és a sérelemdíj

$2017 / 4-6$. 365

2017/1-3.

218

Pintér Tibor - Az európai integráció - gazdasági és politikai

$2017 / 4-6$.

318 alapú elméleti megközelítések

Prugberger Tamás - Rácz Zoltán - A munka- és a

$2017 / 4-6$.

közszolgálati jogi érdekérvényesítés alakulása 2010

után

Sárközy Tamás - A sport mint nemzetstratégiai ágazat.

$2017 / 4-6$.

Elônyök és hátrányok, hosszú távú kilátások 
Schadl György - Az ingófoglalás alapvetô szabályai a

$2017 / 1-3$. bírósági végrehajtási eljárás során

Sebestyén Géza - Proaktivitás és innováció mint a jegybanki

$2017 / 4-6$. megújulás alapjai. Gondolatok A magyar út - célzott jegybanki politika címú tanulmánykötetrôl

Sipos Zoltán - Recenzió a Vezetés a közjó szolgálatában címú könyvrôl

Strelchenko, Inna- The Use of Non-Parametric Criteria for the Evaluation of Similar Patterns in the Behaviour of the Economic System

Szablics Bálint - Quo vadis, avagy a nemzetgazdaság és társadalom fejlôdésének stratégiai kérdései (2. rész)

Szabó Tamás - A területi versenyképesség és a közszolgáltatások hozzáférhetôségének kapcsolata

Szmodis Jenó - A globális integráció eszméjének gyökerei $2017 / 4-6$. 389

$2017 / 4-6$.

Szôke Brigitta - Mack István - Válságkezelés a visegrádi négyek országaiban

Szúts Zoltán - Recenzió a Sajtószabadság és médiajog a 21. század elején címú könyvsorozatról

Tatay Tibor - Neumanné Virág Ildikó - Lentner Csaba Sági Judit - Az otthonteremtési támogatási rendszer értékelése egy kérdôíves vizsgálat tükrében

Tóth Róbert - Mester Éva - Szijártó Boglárka - Túróczi $2017 / 1-3$. Imre - Zéman Zoltán - A vállalkozások beruházási döntéseinek elemzése és kontrollja

Tóth Zoltán József - Az Egyesült Államok alkotmányának kartális és történeti jellege

Varga József - Az iszlám bankrendszer múködése 2017/4-6.

Vehrer Adél - A török viseleti darabok hatása hazánkban a $2017 / 1-3$. 295 hódoltság korában

Veres Lajos - Az állam gazdasági szerepvállalásának $2017 / 1-3$. 256 felértékelődése 
Polgári Szemle

ISSN 1786-6553 